UNIVERSIDADE DE SÃO PAULO

FACULDADE DE ZOOTECNIA E ENGENHARIA DE ALIMENTOS

ADILSON APARECIDO LANÇONI

LEVANTAMENTO DE DEMANDA PARA A GESTÃO INFORMATIZADA DE EMPREENDIMENTOS RURAIS VIS-À-VIS O ACESSO À REDE DE COMPUTADORES NO BRASIL

Pirassununga-SP 
UNIVERSIDADE DE SÃO PAULO

FACULDADE DE ZOOTECNIA E ENGENHARIA DE ALIMENTOS

ADILSON APARECIDO LANÇONI

\section{LEVANTAMENTO DE DEMANDA PARA A GESTÃO INFORMATIZADA DE EMPREENDIMENTOS RURAIS VIS-À-VIS O ACESSO À REDE DE COMPUTADORES NO BRASIL \\ (VERSÃO CORRIGIDA)}

Dissertação apresentada à Faculdade de Zootecnia e Engenharia de Alimentos da Universidade de São Paulo, como parte dos requisitos para a obtenção do título de Mestre em Ciências no Programa de PósGraduação em Gestão e Inovação na Indústria Animal.

Área de Concentração: Gestão e Inovação da Indústria Animal.

Orientador: Prof. Dr. César Gonçalves de Lima

Coorientador: Prof. Dr. Celso da Costa Carrer

Pirassununga-SP 


\section{Ficha catalográfica elaborada pelo}

Serviço de Biblioteca e Informação, FZEA/USP, com os dados fornecidos pelo(a) autor(a)

\begin{tabular}{l} 
Lançoni, Adilson Aparecido \\
Levantamento de demanda para a gestão \\
informatizada de empreendimentos rurais vis-à-vis o \\
acesso à rede de computadores no Brasil / Adilson \\
Aparecido Lançoni ; orientador César Gonçalves Lima ; \\
coorientador Celso da Costa Carrer. -- \\
Pirassununga, 2020. \\
113 f. \\
Dissertação (Mestrado - Programa de Pós-Graduação \\
em Mestrado Profissional Gestão e Inovação na \\
Indústria Animal) -- Faculdade de Zootecnia e \\
Engenharia de Alimentos, Universidade de São Paulo. \\
1. Agronegócio. 2. Produtor rural. 3. Tecnologia \\
da informação. 4. Rede de computadores. 5. Gestão em \\
empreendimentos rurais. I. Lima, César Gonçalves, \\
orient. II. Carrer, Celso da Costa, coorient. III. \\
Título. \\
\hline
\end{tabular}

Permitida a cópia total ou parcial deste documento, desde que citada a fonte - o autor 


\title{
LEVANTAMENTO DE DEMANDA PARA A GESTÃO INFORMATIZADA DE EMPREENDIMENTOS RURAIS VIS-À-VIS O ACESSO À REDE DE COMPUTADORES NO BRASIL
}

\begin{abstract}
Dissertação apresentada à Faculdade de Zootecnia e Engenharia de Alimentos da Universidade de São Paulo, como parte dos requisitos para a obtenção do título de Mestre em Ciências no Programa de PósGraduação em Gestão e Inovação na Indústria Animal.
\end{abstract}

Data de aprovação: 18/09/2020

\section{Banca Examinadora:}

Prof. Dr. Celso da Costa Carrer - FZEA/USP

Presidente da Banca Examinadora/Coorientador

Prof. Dr. Adriano Rogerio Bruno Tech - FZEA/USP

Membro interno ao Programa

Profa. Dr. David Ferreira Lopes Santos - UNESP

Membro externo ao Programa

Profa. Dr. Marcelo Caetano Oliveira Alves - UNIP

Membro externo ao Programa 


\section{DEDICATÓRIA}

Dedico este trabalho aos meus pais Jair e Elvira, a minha esposa Josiana e aos meus filhos Laura e Raul. 


\section{AGRADECIMENTOS}

A DEUS, pelo dom da vida e por ser nossa razão de existência.

Aos meus pais Jair e Elvira por sempre me incentivar aos estudos, mesmo quando eu não estava disposto.

A minha esposa Josiana, sempre compreensiva, companheira na felicidade e nos momentos difíceis e por ser luz na minha vida.

Aos meus filhos Laura e Raul pelo carinho e amor de filhos.

Ao meu Orientador Prof. César Gonçalves de Lima por me aceitar como orientado, pelo exemplo de dedicação na pesquisa científica, de ser para mim referência na estatística e por sempre estar à disposição para sanar minhas dúvidas.

Ao meu Coorientador Prof. Celso da Costa Carrer pela oportunidade de ser seu coorientado, pela sua prestatividade, sempre pontual e organizado na distribuição das demandas na pesquisa, pela sua experiência e contribuição na pesquisa científica.

Aos professores do PPG-GllA e aos membros da banca examinadora por contribuírem na melhoria da pesquisa através dos apontamentos e exemplos de dedicação à pesquisa.

Aos colegas do PPG-GIIA, pelo aprendizado em sala de aula e na vida.

O presente trabalho foi realizado com o apoio da Coordenação de Aperfeiçoamento de Pessoal de Nível Superior (CAPES). 
Amai-vos uns aos outros, como eu vos amei.

Jesus Cristo. 


\section{RESUMO}

As TICs possibilitam o acesso a uma variedade de informações de ordem técnica e geral, que atreladas às ferramentas gerenciais, promovem o auxílio no processo de gestão em todos os segmentos da economia, inclusive no agronegócio. Assim, o produtor rural pode ter ao seu alcance uma gama de recursos tecnológicos (hardwares ou softwares) que possibilitam suprir a ausência ou precariedade de informações técnicas ou financeiras para análise e tomada de decisão, principalmente nas pequenas e médias propriedades, onde o processo decisório é arbitrário ou, simplesmente, intuitivo. Desta forma, o objetivo da pesquisa foi apontar um estudo para levantamento do potencial de demanda e possíveis soluções que possam contribuir na profissionalização da gestão financeira em empreendimentos rurais no Brasil, a partir do uso da rede de computadores. Para tanto, utilizou-se como fonte de dados o Censo Agropecuário - IBGE 2017, para traçar uma caracterização dos empreendimentos rurais e a verificação destes ao acesso à rede de computadores no Brasil em levantamento qualitativo e quantitativo, através de pesquisa com formulários no Google formulários e entrevistas presenciais junto aos proprietários, arrendatários ou gestores profissionais. O estudo mostrou que no segmento do agronegócio ainda existe uma parcela de produtores com uso de caderno de anotações ou caderneta, como único meio de controle das movimentações financeiras, mas com acesso à rede de computadores, através de celular, computador ou notebook, sendo o nível de escolaridade um dos principais fatores de pré-disposição à aderência por tais ferramentas tecnológicas, tipos de controles e índices de gestão. Ao final, o diagnóstico de demanda com futuros consumidores de um sistema denominado Nav Agro Brasil software para auxiliar a gestão de parte das propriedades que possuem acesso à rede, se mostrou promissor no sentido de se pontuar claramente para uma demanda positiva no uso de uma ferramenta de gestão para organização e controle das informações financeiras.

Palavras-chave: agronegócio; empreendimento rural; produtor rural; tecnologia da informação. 


\begin{abstract}
TICs provide access to a variety of technical and general information, which, coupled with managerial tools, promote assistance in the management process in all segments of the economy, including agribusiness. Thus, the rural producer may have at his disposal a range of technological resources (hardware or software) that make it possible to supply the absence or precariousness of technical or financial information for analysis and decision making, especially in small and medium-sized properties, where the decisionmaking process it is arbitrary or, simply, intuitive. Thus, the objective of the research was to point out a study to survey the potential demand and possible solutions that can contribute to the professionalization of financial management in rural enterprises in Brazil, using the computer network. To this end, the Census of Agriculture - IBGE 2017 was used as a data source to trace a characterization of rural enterprises and their verification of access to the computer network in Brazil in a qualitative and quantitative survey, through research with forms on Google forms and face-to-face interviews with owners, lessees or professional managers. The study showed that in the agribusiness segment there is still a portion of producers using notebooks or passbooks, as the only means of controlling financial transactions, but with access to the computer network, via cell phone, computer or notebook, being the education level one of the main factors of pre-disposition to adherence to such technological tools, types of controls and management indexes. In the end, the demand diagnosis with future consumers of a system called Nav Agro Brasil software to assist the management of part of the properties that have access to the network, proved to be promising in the sense of clearly scoring for a positive demand in the use of a management tool for organizing and controlling financial information.
\end{abstract}

Keywords: agribusiness; rural enterprise; rural producer; information technology. 


\section{LISTA DE FIGURAS}

Figura 1 - Número de estabelecimentos agropecuários (unidades) com efetivos da pecuária

Figura 2 - Número de cabeças na pecuária e efetivos, por espécie.

Figura 3 - Relação do PIB total no Brasil em relação ao PIB do agronegócio, no período de 2009 a 2018

Figura 4 - Mercado Brasileiro de Software - Panorama e Tendências - 2019 (América do Sul) .24

Figura 5 - Mercado Brasileiro de Software - Panorama e Tendências - 2019 (Cenário Global). .25

Figura 6 - Domicílios com acesso à internet, por velocidade e conexão. .38

Figura 7 - Domicílios rurais sem acesso à internet, por principal motivo para a falta de internet. 39

Figura 8 - Número de respondentes por região

Figura 9 - Linhas de financiamento rural adquirido pelos estabelecimentos rurais. 49

Figura 10 - Percentual de estabelecimentos rurais com atividades: única e diversificadas. .50

Figura 11 - Percentual de atividades, produtos ou serviços comercializados por Estado. .51

Figura 12 - Percentual de atividades comercializadas por Estado na agricultura .52

Figura 13 - Percentual de atividades comercializadas por Estado na pecuária .53

Figura 14 - Resumo da composição empresária nas propriedades rurais. .54 
Figura 15 - Quantidade de estabelecimentos rurais por nível de escolaridade de quem faz a gestão .55

Figura 16 - Níveis de escolaridade de quem faz a gestão na propriedade. .55

Figura 17 - Faixa etária de quem faz a gestão nas propriedades. .57

Figura 18 - Empreendimentos rurais por tamanho em hectares. .58

Figura 19 - Quantidade de funcionários ou membros familiares por tamanho de propriedade. 58

Figura 20 - Percentual da atividade comerciais com controles de custos produtivos em empreendimentos rurais por definição de quem faz a gestão. .59

Figura 21 - Percentual de existência de controles de custos produtivos nos empreendimentos rurais. 60

Figura 22 - Percentual de controles de custos produtivos nos empreendimentos rurais por tamanho em hectares

Figura 23 - Percentual de controles de custos produtivos nos empreendimentos rurais por nível de escolaridade de quem faz a gestão. .61

Figura 24 - Percentual de controles de custos produtivos nos empreendimentos rurais por quem faz a gestão

Figura 25 - Percentual da atividade comerciais com controles de custos produtivos por tipo de cultura agropecuária. 62

Figura 26 - Percentual dos tipos de registros das movimentações financeiras utilizados nos empreendimentos rurais por quem faz a gestão. 63

Figura 27 - Percentual dos tipos de registros das movimentações financeiras utilizados nos empreendimentos rurais por nível de escolaridade de quem faz a gestão. .64 
Figura 28- Percentual dos tipos de registros das movimentações financeiras utilizados nos empreendimentos rurais por nível de escolaridade de quem faz a gestão .65

Figura 29 - Percentual das formas de registro das movimentações financeiras utilizados nos empreendimentos rurais por quem faz a gestão.

Figura 30 - Formas de registro das movimentações financeiras nos empreendimentos rurais por tamanho em hectares.

Figura 31 - Local de registro das movimentações financeiras dos empreendimentos rurais. 68

Figura 32 - Percentual dos regimes tributários adotados nos empreendimentos rurais por quem faz a gestão...

Figura 33 - Percentual dos regimes tributários adotados em empreendimentos rurais por tamanho em hectares.

Figura 34 - Percentual das informações ou índices levados em consideração para a tomada decisória nos empreendimentos rurais. .70

Figura 35 - Percentual das informações ou índices levados em consideração para a tomada decisória nos empreendimentos rurais por nível de formação de quem faz a gestão.

Figura 36 - Percentual de percepção dos gestores dos empreendimentos rurais com o lucro nos últimos 5 anos. .72

Figura 37 - Percentual das variáveis que influenciaram positivamente no lucro dos empreendimentos rurais. .73

Figura 38 - Percentual das variáveis que influenciaram negativamente no lucro dos empreendimentos rurais. .74

Figura 39 - Percentual dos gestores de empreendimentos rurais que acompanham preços e informações sobre o comportamento de mercado. 
Figura 40 - Percentual das fontes utilizadas para acompanhamento de preços e informações sobre comportamento de mercado nos empreendimentos rurais .75

Figura 41 - Percentual de observação dos gestores dos empreendimentos rurais quanto ao mercado que estão inseridos (visão futura) 76

Figura 42 - Percentual de observação dos gestores dos empreendimentos rurais quanto ao mercado que estão inseridos (visão futura) por nível de escolaridade de quem faz a gestão 77

Figura 43 - Percentual de carência por serviço de gestão nos empreendimentos rurais. .78

Figura 44 - Percentual de gestores dispostos a conhecer uma proposta de sistema de gestão que visse a contribuir na tomada decisória nos empreendimentos rurais 79

Figura 45 - Percentual de empreendimentos rurais com acesso à internet .80

Figura 46 - Tipos de conexões para o acesso à internet nos empreendimentos rurais ....81

Figura 47 - Tipos de conexões à internet e as velocidades de download das conexões dos empreendimentos rurais. .82

Figura 48 - Recursos tecnológicos (hardware) utilizados para acesso à internet nos empreendimentos rurais .83

Figura 49 - Percentual dos recursos tecnológicos (hardware) utilizados para acessar à internet por nível de escolaridade de quem faz a gestão no empreendimento rural..... 84

Figura 50 - Percentual de conhecimento do sistema Nav Agro Brasil por quem faz a gestão nos empreendimentos rurais.

Figura 51 - Percentual de interesse em receber informações detalhadas sobre o sistema Nav Agro Brasil por quem faz a gestão nos empreendimentos rurais 85 
Figura 52 - Visualização da relação de dependência entre as variáveis: recursos tecnológicos e tipos de controle através dos dados gerados pela análise por correspondência simples.

Figura 53 - Uso de tecnologias para controle financeiro em empreendimentos rurais......87

Figura 54 - Visualização da relação de dependência entre as variáveis: recursos tecnológicos e nível de escolaridade através dos dados gerados pela análise por correspondência simples.

Figura 55 - Uso de tecnologias para controle financeiro e o nível de escolaridade de quem faz a gestão.

Figura 56 - Visualização da relação de dependência entre as variáveis: tipos de controles e nível de escolaridade através dos dados gerados pela análise por correspondência simples.

Figura 57 - Uso de controles financeiro e o nível de escolaridade de quem faz a gestão.

Figura 58 - Visualização da relação de dependência entre as variáveis: tipos de controles e nível de escolaridade através dos dados gerados pela análise por correspondência simples.

Figura 59 - Uso de índice de gestão e tipos de controles utilizados por quem faz a gestão. .93

Figura 60 - Visualização da relação de dependência entre as variáveis: conexões e velocidades de download através dos dados gerados pela análise por correspondência simples. 


\section{LISTA DE QUADROS}

Quadro 1 - Estudos e conclusões sobre a utilização da tecnologia da informação em empreendimentos rurais. .23

Quadro 2 - O mercado nacional de tecnologia da informação - 2018 (US\$ Milhões).......25 Quadro 3 - Receita total de software de CRM, por fornecedor, no Mundo em 2018 (em Dólares). .26

Quadro 4 - Segmentação dos principais mercados Brasileiro de software. .26

Quadro 5 - Segmentação dos principais mercados usuários de software. .27

Quadro 6 - A adoção de TIC ainda é um problema e o financiamento público para os Serviços Agrícolas de TIC justifica? (\% de respostas "Sim"). .29

Quadro 7 - Quais são os fatores que limitam o uso de TIC pelos agricultores (\% de respostas "Sim").

Quadro 8 - Centros de pesquisas e algumas das soluções de TICs no agronegócio brasileiro.

Quadro 9 - Soluções tecnológicas aplicadas ao agronegócio brasileiro - Programa GIIA. 32

Quadro 10 - Ferramentas de gestão combinadas ou não ao uso de software em empreendimentos rurais. .33

Quadro 11 - Resumo dos principais indicadores de desempenhos atrelado ao uso de software. 


\section{LISTA DE TABELAS}

Tabela 1 - PIB do agronegócio - variação do ramo agrícola nos últimos dez anos.........17

Tabela 2 - Concentração da produção agrícola por regiões no Brasil...............................17

Tabela 3 - PIB do agronegócio - variação anual do ramo pecuário nos últimos dez

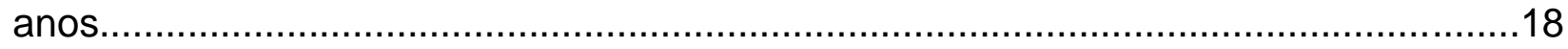

Tabela 4 - Percentual de software rural ofertado, por categoria (2011) .........................27

Tabela 5 - Softwares ofertados para o agronegócio, por áreas de aplicação na categoria

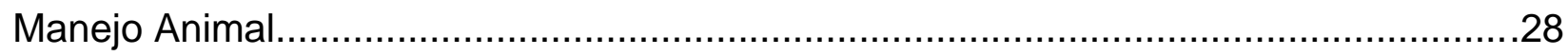

Tabela 6 - Estabelecimentos agropecuários por região (com e sem acesso à internet)....36

Tabela 7 - Tipos de conexão à internet nos estabelecimentos agropecuários...................37

Tabela 8 - Meios alternativos de comunicação e coleta de informações aos agentes entrevistados. 


\section{LISTA DE SIGLAS E ABREVIATURAS}

ABDI

ABES

ANATEL

ATM

BNDES

CEPEA

CETIC

$\mathrm{CPqD}$

CRM

EMBRAPA

EMBRAPII

FINEP

FTTx,

FUNTTEL

GPS

IBGE

INCRA

INTERNETLAB
Agência Brasileira de Desenvolvimento Industrial

Associação Brasileira das Empresas de Softwares

Agência Nacional de Telecomunicações

Asynchronous Transfer Mode

Banco Nacional de Desenvolvimento Econômico e Social

Centro de Estudos Avançados em Economia Aplicada

Centro Regional de Estudos para o Desenvolvimento da Sociedade da Informação

Centro de Pesquisa e Desenvolvimento em Telecomunicações

Customer, Relationship Manager

Empresa Brasileira de Pesquisa Agropecuária

Empresa Brasileira de Pesquisa e Inovação Industrial

Fundo de Financiamentos de Estudos de Projetos e Programas

Fiber Drop Cable

Fundo para o Desenvolvimento Tecnológico das Telecomunicações

Global Positioning System

Instituto Brasileiro de Geografia e Estatística

Instituto Nacional de Colonização e Reforma Agrária

Centro de Pesquisa Interdisciplinar em Direito da Tecnologia 
ISA Indicadores de Sustentabilidade em Agroecossistemas

LABEX Laboratórios Virtuais no Exterior

MAPA Ministério da Agricultura, Pecuária e Abastecimento

PIB Produto Interno Bruto

PRONAF Programa Nacional de Fortalecimento da Agricultura Familiar

TICs Tecnologias de informação e comunicação

Usad United States Department of Agriculture

xDSL Digital Subscriber Line 


\section{SUMÁRIO}

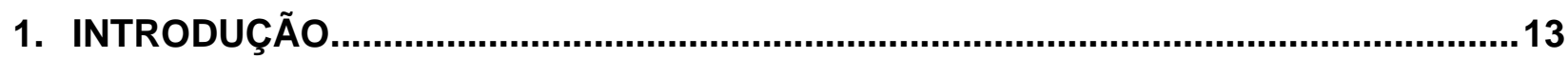

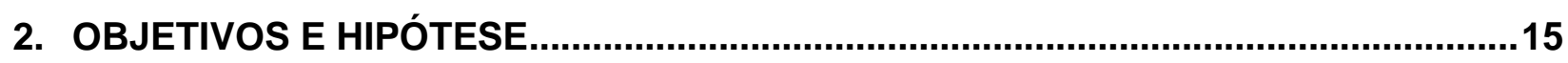

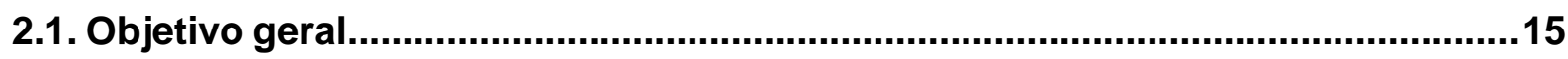

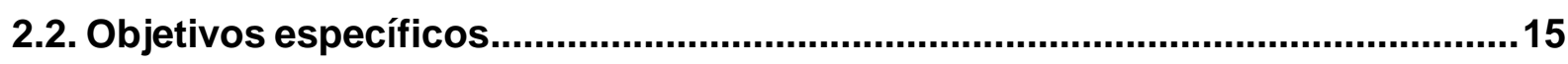

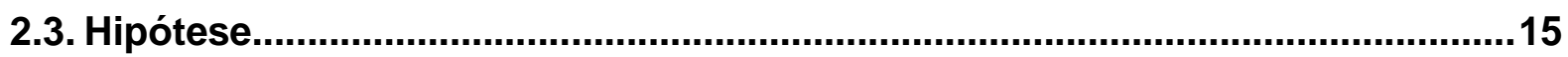

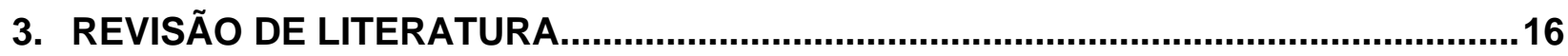

3.1. Contexto e importância do agronegócio brasileiro na última década.................16

3.2. A importância da tecnologia da informação para a profissionalização dos

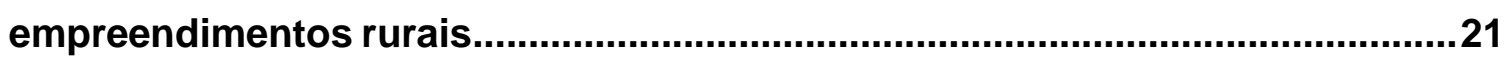

3.3. Ferramentas de gestão e acesso à rede de computadores para

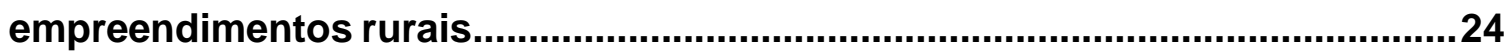

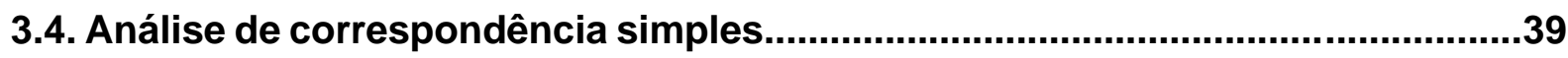

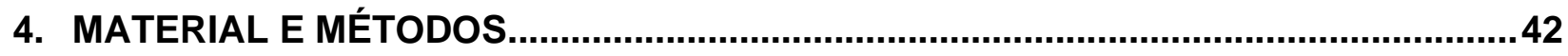

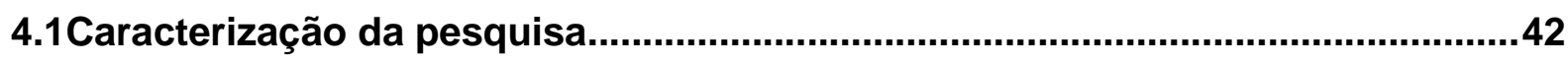

4.2 Dados qualitativos e aspectos éticos da pesquisa..................................................43

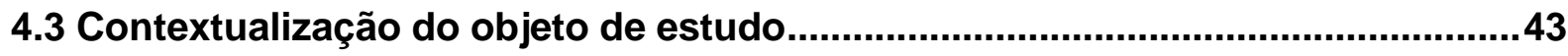

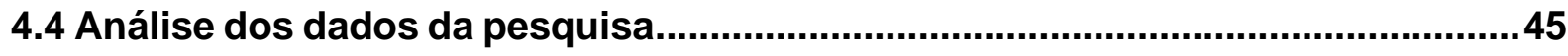

4.5 Oportunização do software Nav Agro Brasil.......................................................46

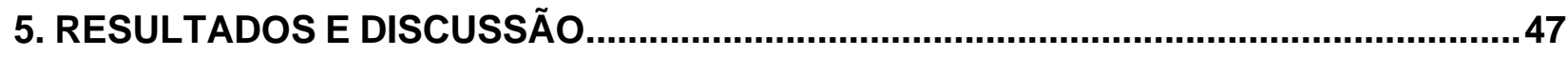

5.1 Linhas de financiamentos adquiridos pelos empreendimentos rurais................48

5.2 Ramo(s) de atividade(s), produto(s) ou serviço(s) comercializado(s) pelo empreendimento rural e suas respectivas localidades.

5.3 Perfil dos gestores e composição empresária dos empreendimentos rurais.....53 5.4 Tamanho (em hectares) dos empreendimentos rurais e a estrutura operacional de funcionários ou membros familiares empregados nas atividades comerciais....57 5.5 Controles de custos produtivos nos empreendimentos rurais e suas prerrogativas quanto à existência, gestão, tipos, nível de escolaridade dos usuários

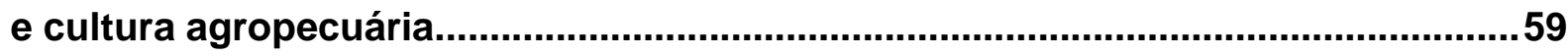
5.6 Tipos e formas de controle e registro das movimentações financeiras nos empreendimentos rurais. 
5.7 Regimes tributários praticados na comercialização dos produtos ou serviços nos empreendimentos rurais.

5.8 Principais informações ou índices levados em consideração no auxílio à tomada de decisão na comercialização dos produtos ou serviços nos empreendimentos rurais.

5.9 Nível de percepção quanto ao resultado (lucro) dos empreendimentos rurais nos últimos 5 anos e principais variáveis influenciáveis.

5.10 Nível de carência por serviço de gestão nos empreendimentos rurais e predisposição em conhecer novas ferramentas de apoio à gestão . .77

5.11 Acesso à rede de computadores no Brasil pelos gestores dos empreendimentos rurais.

5.12 Percepção dos gestores quanto ao conhecimento do sistema (Nav Agro Brasil) a ser proposto como ferramenta de gestão para controle e organização das informações financeiras nos empreendimentos rurais.

5.13 Aplicação da análise multivariada por correspondência. .86

5.13.1 Conjunto de variáveis categóricas de análise por correspondência: recursos tecnológicos e tipos de controles. 86

5.13.2 Conjunto de variáveis categóricas de análise por correspondência: recursos tecnológicos e nível de escolaridade.

5.13.3 Conjunto de variáveis categóricas de análise por correspondência: tipos de controles e nível de escolaridade.

5.13.4 Conjunto de variáveis categóricas de análise por correspondência: índices de gestão e tipos de controles.

5.13.5 Conjunto de variáveis categóricas de análise por correspondência: conexões e velocidades de download.

6. CONSIDERAÇÕES FINAIS.

7. REFERÊNCIAS

APÊNDICE 1 - QUESTIONÁRIO DA PESQUISA 107

APÊNDICE 2 - ESTRUTURA FUNCIONAL DO SOFTWARE NAV AGRO BRASIL.....112 ANEXO 1 - CERTIFICADO DE REGISTRO DO PROGRAMA DE COMPUTADOR.....113 


\section{INTRODUÇÃO}

Uma boa gestão é um fator crucial para o sucesso de qualquer negócio, e os estabelecimentos agropecuários, não são uma exceção. Para ter o sucesso, os gestores de hoje precisam passar mais tempo tomando decisões e desenvolvendo habilidades que seus pais ou avós precisavam (KAY et al. 2014). Assim, administrar um empreendimento rural requer, além do domínio técnico da agricultura ou pecuária, um conjunto de habilidades, incluindo uso das tecnologias de informação (TICs), como forma contínua por busca de informações, em tempo real e atualizadas, para a boa conduta dos processos decisórios e dos resultados.

Desta forma, os gestores de empreendimentos rurais necessitam constantemente por uso de informações, a partir da coleta de dados dos insumos produtivos, tendências de mercado, relacionamento e oferta do produto ao cliente, entre outras, através da rede mundial de computadores. Contudo, de acordo com o Censo do IBGE (2017), há uma parcela que ainda é privada ao acesso à rede de computadores no Brasil, com maior relevância nas regiões Norte, Nordeste e Centro-Oeste, o que dificulta a profissionalização do segmento, bem como, o comprometimento futuro do negócio.

Partindo desta realidade, torna-se necessário que os produtores, normalmente defasados tecnologicamente, a priori, tenham acesso a ferramentas que permitam tornar o empreendimento mais competitivo (MACHADO; NANTES, 2011). Neste contexto, políticas governamentais de acesso à tecnologia da informação (TI) se apresentam como um facilitador deste processo, possibilitando aos mais vulneráveis e menos capitalizados, o acesso às tecnologias que reúnem uma gama de elementos fundamentais para o apoio à gestão administrativa.

Essas tecnologias podem ser entendidas como tudo o que envolva hardware (parte física): computadores, smartphones, aparelhos GPS, maquinários computadorizados, etc.; e software (parte lógica): programas de computador, aplicativos mobile, sistemas de informações, etc. (FERRAZ; PINTO, 2017). A adoção dessas tecnologias também possibilita a execução de um grande volume de operações 
numéricas em alta velocidade, a comunicação ágil e segura, o armazenamento de grande volume de informações em pouco espaço e com rápido acesso (BORGES, 2015).

De um lado há de se ressaltar que o nível de instrução do produtor rural e, portanto, parte de sua habilidade em manusear essa tecnologia, combinada com a falta de infraestrutura de telecomunicações em muitos empreendimentos rurais, tendem a ser entraves e precisariam ser alvos de políticas públicas e privadas para a melhoria das ferramentas de gestão disponíveis, incluindo a ampliação do acesso à rede de computadores em áreas com limitação de uso. Por outro lado, o agronegócio tem um peso significativo no PIB do Brasil e carece de soluções tecnológicas contributivas para parte da profissionalização na gestão financeira de seu empresariado como fator de sobrevivência.

Partindo dessas premissas, este trabalho objetiva realizar um levantamento, de natureza qualitativa e quantitativa, sobre o potencial de utilização de ferramentas computadorizadas para a gestão das empresas rurais no país. Para isso, foi realizado levamento de referencial teórico acerca do contexto e importância do agronegócio brasileiro na última década, ressaltando assim, aspectos produtivos e de relevância para o desenvolvimento econômico do País. Também, uma abordagem da importância da tecnologia da informação para a profissionalização dos empreendimentos rurais evidenciando a necessidade pelo uso de ferramentas tecnológicas, bem como, seus reflexos na gestão dos negócios. Adiante, os cenários brasileiro e mundial do mercado de ferramentas de gestão e fatores determinantes, apontando algumas ferramentas e indicadores de custos existentes, bem como, um panorama dos estabelecimentos rurais com acesso à rede de computadores segundo IBGE (2017). A seguir, buscou-se trazer informações da ferramenta informatizada denominada Nav Agro Brasil - um software com proposta no auxílio de controle e gestão das informações financeiras das propriedades que possuem acesso à rede, face à demanda identificada junto aos agentes entrevistados. Por fim, um diagnóstico dos principais fatores determinantes que reforçam a hipótese de que há potencial do uso de ferramentas remotas de gestão para controle e auxílio às tomadas de decisão na área financeira/contábil em empreendimentos rurais, vis-à-vis o acesso à rede de computadores. 


\section{OBJETIVOS E HIPÓTESE}

\subsection{Objetivo geral}

Buscou-se detectar o potencial do uso de ferramentas de gestão para controle e auxílio às tomadas de decisão dentro das propriedades rurais vis-à-vis o acesso à rede de computadores no Brasil.

\subsection{Objetivos específicos}

a) Analisar, qualitativa e quantitivamente, o potencial da utilização das tecnologias de informação e comunicação na gestão dos empreendimentos rurais, demarcando-se as zonas de maior demanda por serviços especializados;

b) Verificar a demanda de informações para a melhoria da gestão nos empreendimentos rurais, através de pesquisa qualitativa e quantitativa junto aos atores e os principais fatores determinantes da limitação ao uso ou acesso à rede de computadores no Brasil;

c) Desenvolver um levantamento do potencial de se propor o uso de ferramenta remota de gestão para organização e controle das informações financeiras/contábeis, por meio do software denominado Nav Agro Brasil.

\subsection{Hipótese}

A hipótese a ser confirmada na atual pesquisa, parte do pressuposto que existe potencial do uso de ferramentas remotas de gestão para controle e auxílio às tomadas de decisão na área financeira/contábil em empreendimentos rurais, vis-à-vis o acesso à rede de computadores. 


\section{REVISÃO DE LITERATURA}

\subsection{Contexto e importância do agronegócio brasileiro na última década}

Nos últimos dez anos, o Produto Interno Bruno (PIB) do agronegócio brasileiro apresentou um crescimento expressivo de 70,36\% segundo (CEPEA, 2019). Em 2018, foram 1.432.770 trilhões correntes em movimento nas cadeias produtivas: insumos para a agropecuária, produção agropecuária básica, ou primária, agroindústria (processamento) e agro serviços. Verifica-se, no estudo, que o segmento agrícola (setor vegetal) se destaca de forma significativa com $72,92 \%$ do PIB Agropecuário, resultando o segmento pecuário (setor animal) com $27,08 \%$ do montante movimentado em 2018 . De um lado, nos últimos dez anos, o segmento agrícola (vegetal) teve alguns períodos de baixa (de 2012 a 2014) e, por outro, um expressivo crescimento em 2016 quando comparado a 2015, na ordem de 10,62\% e 4,6\% em 2018 comparado a 2017, como observado na Tabela 1.

O Censo Agropecuário (IBGE, 2017), apurou que o segmento agrícola, representado pelas atividades de: extração vegetal, horticultura, floricultura, lavoura temporária e permanente, sementes e mudas certificadas e silvicultura, movimentaram cerca de 9.969.852 estabelecimentos com atividades produtivas simultâneas, divididos pelas regiões Nordeste 47,26\%, Sul 23,71\%, Sudeste 15,97\%, Norte 10,37\% e CentroOeste $2,68 \%$. Juntos, estes estabelecimentos produziram o equivalente a 965.190 .915 em quantidade de produtos agrícolas (Tabela 2), assim distribuídos pelas seguintes regiões: 
Tabela 1 - PIB do agronegócio - variação do ramo agrícola nos últimos dez anos.

\begin{tabular}{|c|c|c|c|c|c|c|c|c|c|c|}
\hline Período & (A) & $\begin{array}{c}\text { Var. } \\
\text { ano } x \\
\text { ano }\end{array}$ & (B) & $\begin{array}{l}\text { Var. } \\
\text { ano } x \\
\text { ano }\end{array}$ & (C) & $\begin{array}{c}\text { Var. } \\
\text { ano } x \\
\text { ano }\end{array}$ & (D) & $\begin{array}{c}\text { Var. } \\
\text { ano } x \\
\text { ano }\end{array}$ & $(\mathrm{A}+\mathrm{B}$ & $\begin{array}{c}\text { Var. } \\
\text { ano } x \\
\text { ano }\end{array}$ \\
\hline 2009 & 40.337 & - & 177.364 & - & 345.210 & - & 388.240 & - & 951.151 & - \\
\hline 2010 & 41.202 & $2,15 \%$ & 221.806 & $25,06 \%$ & 352.221 & $2,03 \%$ & 410.155 & $5,64 \%$ & 1.025 .385 & $7,80 \%$ \\
\hline 2011 & 43.357 & $5,23 \%$ & 270.082 & $21,77 \%$ & 341.187 & $-3,13 \%$ & 412.669 & $0,61 \%$ & 294 & $4,09 \%$ \\
\hline 2012 & 45.5 & $5,02 \%$ & 245.061 & $-9,26 \%$ & 335 & $-1,71 \%$ & 398 & $-3,50 \%$ & 03 & $-4,04 \%$ \\
\hline 2013 & 48.333 & $6,15 \%$ & 227.260 & $-7,26 \%$ & 325. & $-2,84 \%$ & 383 & $-3,65 \%$ & 19 & $-3,82 \%$ \\
\hline 2014 & 46 & $-4,42 \%$ & 21 & $-7,53 \%$ & 315 & $-3,06 \%$ & 368 & $-4,03 \%$ & 29 & $-4,54 \%$ \\
\hline 2015 & 44 & $-3,86 \%$ & 21 & $1,67 \%$ & 324 & $2,61 \%$ & 385 & 4,7 & 23 & $2,90 \%$ \\
\hline 2016 & 42.938 & $-3,32 \%$ & 254.584 & $19,16 \%$ & 344.726 & $6,36 \%$ & 428 & $11,09 \%$ & 542 & $10,62 \%$ \\
\hline 2017 & 41.143 & $-4,18 \%$ & 242.834 & $-4,62 \%$ & 328.412 & $-4,73 \%$ & 401.301 & $-6,30 \%$ & 1.013 .689 & $-5,31 \%$ \\
\hline 2018 & 47.873 & $16,36 \%$ & 242.577 & $-0,11 \%$ & 345.511 & $5,21 \%$ & 424.334 & $5,74 \%$ & 1.060 .295 & $4,60 \%$ \\
\hline
\end{tabular}

(A) Insumos; (B) Agropecuária; (C) Indústria; (D) Serviços; (A)+(B)+(C)+(D) Ramo Agrícola Fonte: CEPEA (2019)

Tabela 2 - Concentração da produção agrícola por regiões no Brasil.

\begin{tabular}{lcrrrr}
\hline Regiões & $\begin{array}{c}\text { Extração } \\
\text { Vegetal }\end{array}$ & Horticultura & $\begin{array}{c}\text { Cultura } \\
\text { Permanente }\end{array}$ & $\begin{array}{c}\text { Cultura } \\
\text { Temporária }\end{array}$ & Silvicultura \\
\hline Norte & 506.423 & 156.069 & 1.794 .798 & 13.160 .053 & 76.966 \\
Nordeste & 162.549 & 837.297 & 4.205 .105 & 64.684 .553 & 133.328 \\
Sudeste & 17.257 & 4.886 .410 & 19.807 .502 & 460.166 .122 & 655.760 \\
Sul & 141.163 & 1.756 .553 & 4.478 .357 & 135.255 .588 & 1.401 .150 \\
Centro-Oeste & 17.706 & 485.899 & 384.187 & 249.422 .474 & 597.644 \\
\hline Brasil & 845.099 & 8.122 .228 & 30.669 .949 & 922.688 .789 & 2.864 .850 \\
\hline
\end{tabular}

Fonte: IBGE - Censo Agropecuário (2017)

$\mathrm{Na}$ extração vegetal, a região Norte se destaca com a produção de açaí, representando $87 \%$ em relação ao volume total produzido; na horticultura a região Sudeste puxa a produção de mudas para plantio, na ordem de $22 \%$ do volume total; nas culturas permanente e temporária a região Sudeste impulsiona com a produção de laranja (fruta) em $71 \%$ do volume total e com $91 \%$ na produção de cana-de-açúcar, respectivamente; a região Sul se destaca em áreas colhidas de eucalipto o qual representa $84 \%$ do volume total colhido na região. 
Seguindo (CEPEA, 2019), a pecuária movimentou 27,08\% do Produto Interno Bruto (PIB) do agronegócio, numa escala menor que o segmento agrícola, mas de forma contributiva no destaque econômico. Nota-se que, nos últimos dez anos, a pecuária apresentou uma redução de $10,91 \%$ em 2018 , quando comparado a 2017 , e outros períodos de baixa, como $2011 \times 2010 ; 2012 \times 2011$; 2017 × 2016; dois períodos positivos de 19,51\% em 2013 × 2012 e 2014 × 2013. Percebe-se um constante declínio nos últimos 5 anos conforme a Tabela 3 .

Tabela 3 - PIB do agronegócio - variação anual do ramo pecuário nos últimos dez anos.

\begin{tabular}{rcccccccccc}
\hline Período & (A) & $\begin{array}{c}\text { Var. } \\
\text { ano } x \\
\text { ano }\end{array}$ & (B) & $\begin{array}{c}\text { Var. ano } \\
\text { xano }\end{array}$ & (C) & $\begin{array}{c}\text { Var. ano } \\
\text { xano }\end{array}$ & (D) & $\begin{array}{c}\text { Var. ano } \\
\text { xano }\end{array}$ & $\begin{array}{c}(\mathrm{A}+\mathrm{B}+\mathrm{C}+\mathrm{D}) \\
\text { Var. ano } \\
\text { xano }\end{array}$ \\
\hline 2009 & 19.618 & - & 84.388 & - & 84.305 & - & 167.447 & - & 355.758 & - \\
2010 & 19.602 & $-0,08 \%$ & 96.837 & $14,75 \%$ & 89.690 & $6,39 \%$ & 181.716 & $8,52 \%$ & 387.846 & $9,02 \%$ \\
2011 & 22.200 & $13,25 \%$ & 95.968 & $-0,90 \%$ & 80.687 & $-10,04 \%$ & 161.473 & $-11,14 \%$ & 360.329 & $-7,09 \%$ \\
2012 & 21.955 & $-1,10 \%$ & 80.835 & $-15,77 \%$ & 73.658 & $-8,71 \%$ & 142.490 & $-11,76 \%$ & 318.938 & $-11,49 \%$ \\
2013 & 21.597 & $-1,63 \%$ & 111.590 & $38,05 \%$ & 81.985 & $11,30 \%$ & 165.995 & $16,50 \%$ & 381.167 & $19,51 \%$ \\
2014 & 21.645 & $0,22 \%$ & 126.626 & $13,47 \%$ & 89.287 & $8,91 \%$ & 187.247 & $12,80 \%$ & 424.805 & $11,45 \%$ \\
2015 & 21.882 & $1,09 \%$ & 124.260 & $-1,87 \%$ & 96.772 & $8,38 \%$ & 208.428 & $11,31 \%$ & 451.342 & $6,25 \%$ \\
2016 & 24.341 & $11,24 \%$ & 126.856 & $2,09 \%$ & 96.231 & $-0,56 \%$ & 208.082 & $-0,17 \%$ & 455.510 & $0,92 \%$ \\
2017 & 21.948 & $-9,83 \%$ & 111.506 & $-12,10 \%$ & 94.317 & $-1,99 \%$ & 200.377 & $-3,70 \%$ & 428.149 & $-6,01 \%$ \\
2018 & 23.044 & $4,99 \%$ & 104.329 & $-6,44 \%$ & 84.228 & $-10,70 \%$ & 169.846 & $-15,24 \%$ & 381.447 & $-10,91 \%$ \\
\hline
\end{tabular}

(A) Insumos; (B) Agropecuária; (C) Indústria; (D) Serviços; (A)+(B)+(C)+(D) Ramo Agrícola Fonte: CEPEA (2019).

O Censo Agropecuário (IBGE, 2017), constatou ainda que há 4.006.656 estabelecimentos agropecuários concentrados na ordem de $45,22 \%$ na região Nordeste, $18,59 \%$ no Sudeste,17,45\% no Sul, $10,80 \%$ no Norte, e $7,94 \%$ no Centro-Oeste. Este efetivo da pecuária compreendem as seguintes espécies: bovinos; bubalinos; equinos; asininos; muares; caprinos; ovinos; suínos e aves (galinhas, galos, frangas, frangos e pintos); codornas, patos, gansos, marrecos, perdizes e faisões; perus; avestruzes e coelhos como pode-se observar na Figura 1. 
Figura 1 - Número de estabelecimentos agropecuários (unidades) com efetivos da pecuária.

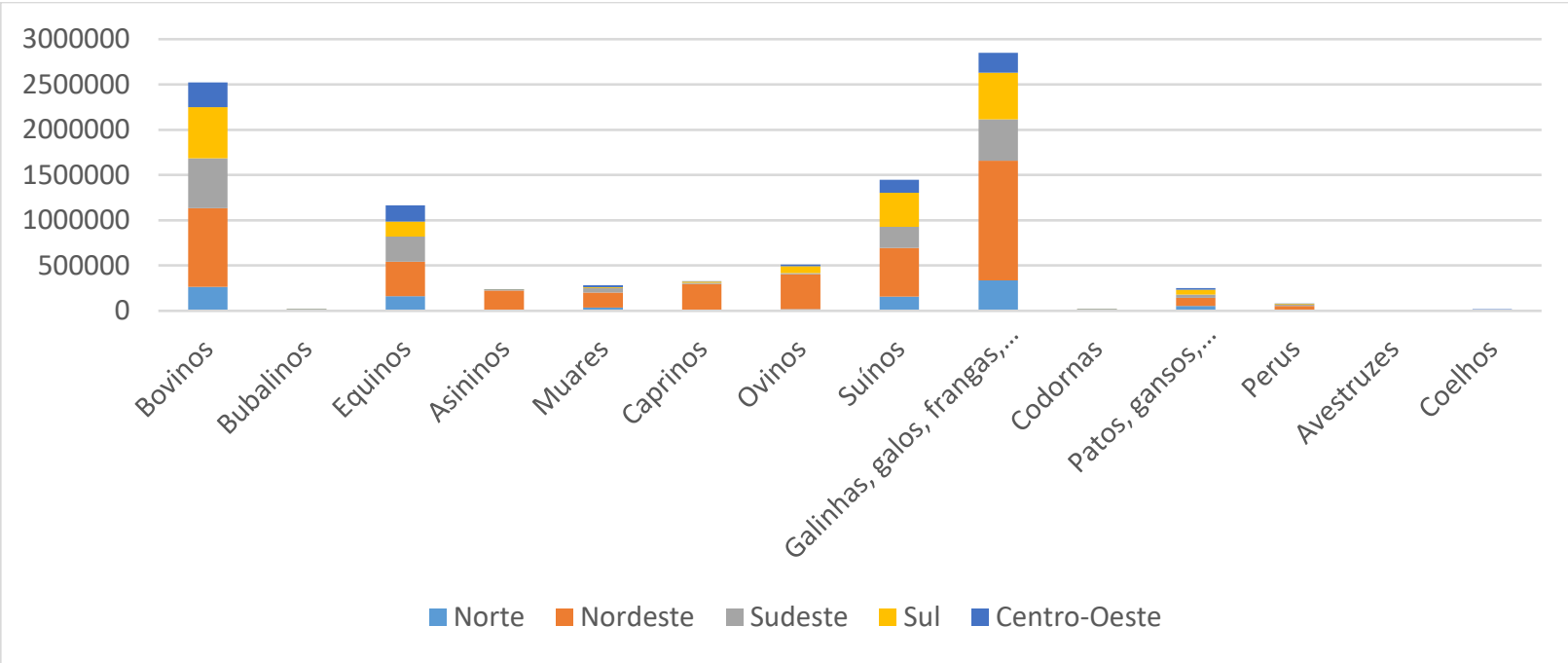

Fonte: IBGE - Censo Agropecuário (2017)

O estudo também constatou que o Brasil tem uma concentração de 1.637.459.361 de cabeças em espécies da pecuária, como demonstrado na Figura 2.

Figura 2 - Número de cabeças na pecuária e efetivos, por espécie.

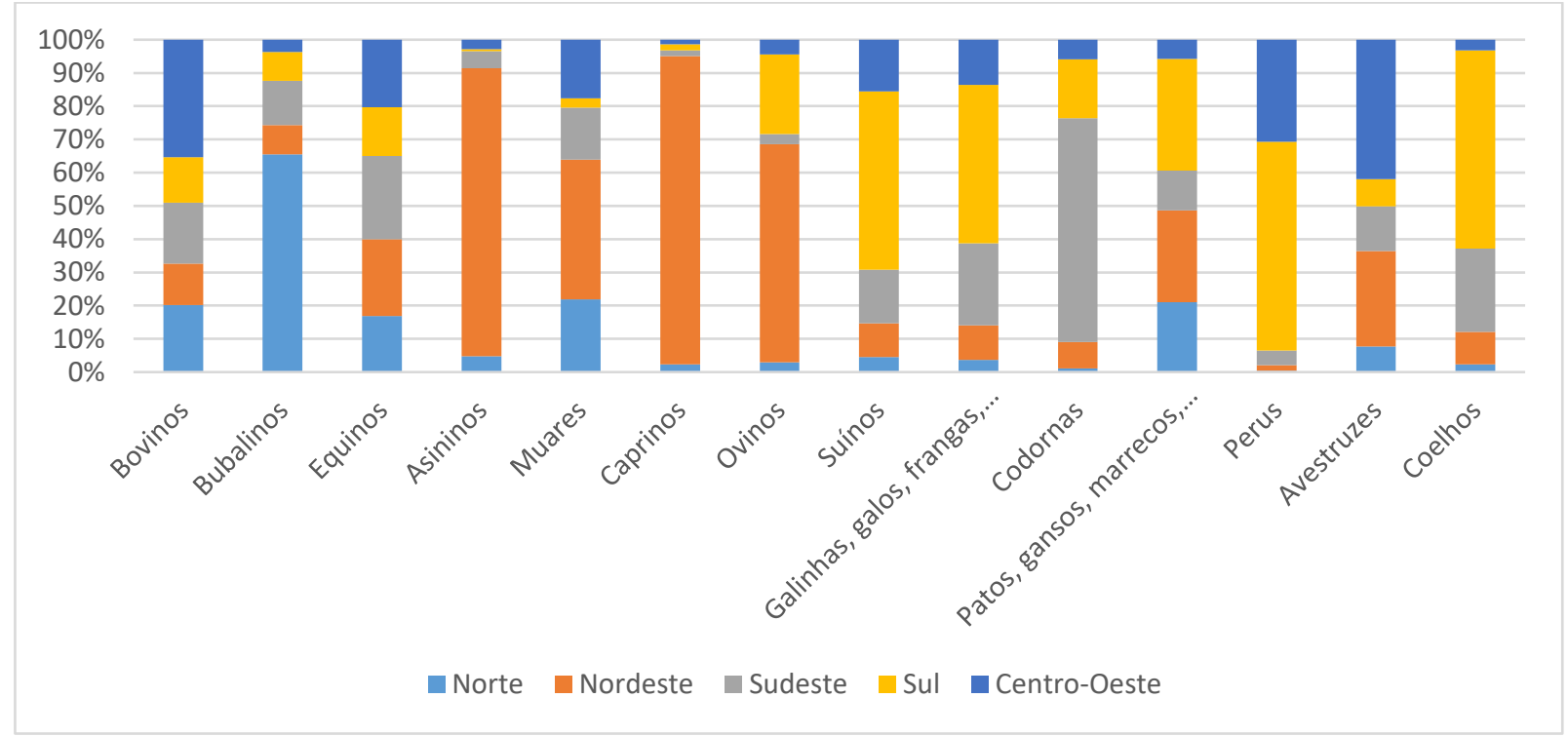

Fonte: IBGE - Censo Agropecuário (2017) 
Nota-se que, quando observadas em valores agregados de cabeças, a região Sul apresenta a maior concentração de rebanhos com $43,43 \%$ (alavancada pelo número maior de aves e suínos), seguido pela região Sudeste $23,68 \%$, região Centro-Oeste 15,90\%, Nordeste 11,48\% e Norte 5,51\%. Em termos de concentração por espécie, salvo exceção às aves, verifica-se que a região Centro-Oeste se destaca na concentração de bovinos. A região Norte se destaca com o número de bubalinos enquanto a região Sudeste com equinos. A região Nordeste se destaca no número de cabeças de asininos, muares, caprinos e ovinos. Por fim, a região Sul fica com a maior parte de suínos

Esse movimento da cadeia produtiva do agronegócio impacta, de forma representativa, no comportamento do Produto Interno Bruto (PIB) - Brasil, definido como a soma (em valores monetários) das atividades econômicas: agrícola, indústria e serviços. Nota-se que o agronegócio correspondeu a 21,1\% em 2018 do PIB - Brasil. Muito embora tenha um crescimento de 2,28\%, de 2018 em relação a 2017, e nos últimos dez anos de 99,74\%, o agronegócio quando comparado as atividades de indústria e serviços encontra-se estagnado no último triênio (2016 a 2018), como observado na Figura 3.

Figura 3 - Relação do PIB total no Brasil em relação ao PIB do agronegócio, no período de 2009 a 2018.

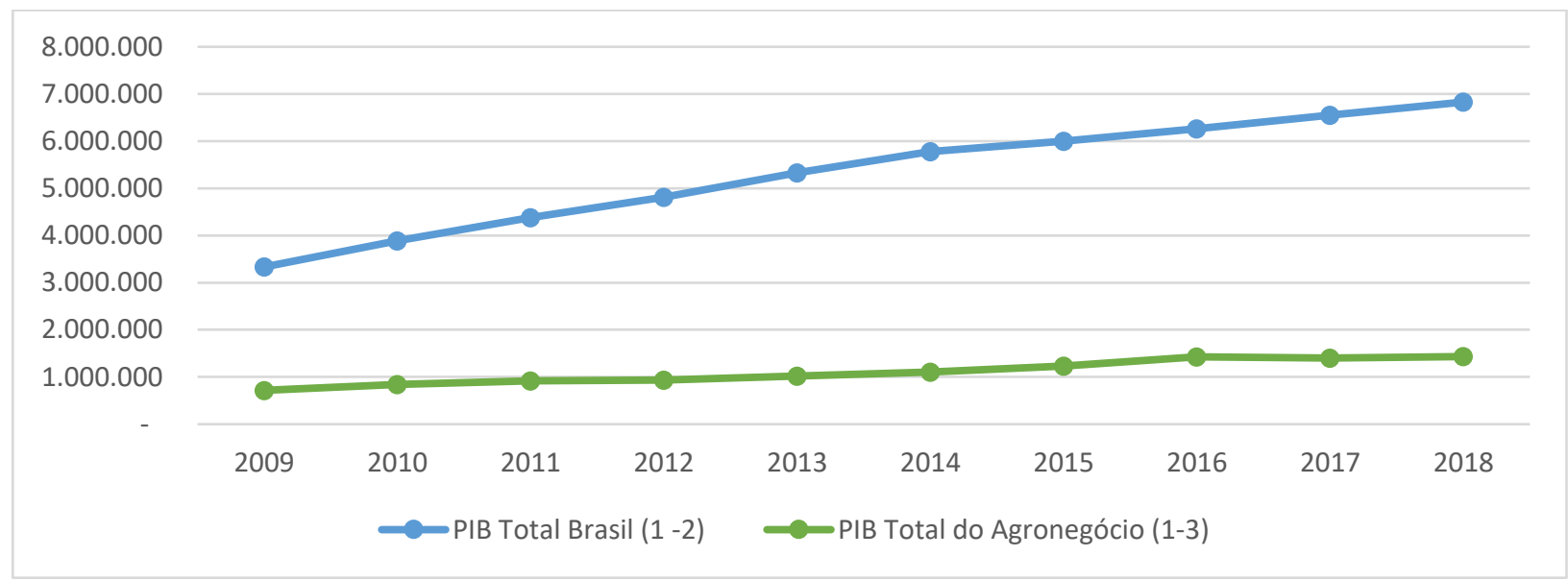

Fonte: CEPEA (2019)

(1) (a preços de mercado em $\mathrm{R} \$$ milhões correntes)

(2) atividades econômicas: agrícola, indústria e serviços

(3) somatório da cadeia produtiva: insumos, agropecuária, indústria e serviços. 
Parte dos motivos da estagnação do agronegócio em 2017 e 2018, segundo o MAPA (2018), foi reflexo da produção recorde de grãos (super safra) atrelada à queda dos preços internacionais com soja e derivados, carnes, café e outros. Não obstante, a paralização dos caminhoneiros, ocorrida ao longo de maio de 2018, também contribuiu para o desempenho melhor que 2016, segundo o PARANÁ PORTAL (2019). Neste sentido, o uso das TICs são fundamentais para o reposicionamento estratégico dos empreendimentos rurais em situações de mercados interno e externo, em que, na maioria das vezes, o gestor não tem domínio sobre preços e outras variáveis externas à sua unidade de produção, restando-lhe a possibilidade de se informar e definir prioridades na gestão de custos para a condução dos negócios.

\subsection{A importância da tecnologia da informação para a profissionalização dos empreendimentos rurais}

Cerca de 2,5 bilhões de pessoas no mundo estão inseridas diretamente na agricultura, num contingente de 500 milhões de pequenas propriedades rurais - dos quais $80 \%$ são geridos por pequenos agricultores (SACHS, 2019). Essa massa de produtores responde à uma parcela significativa do alimento consumido nos países desenvolvidos.

Nota-se que, mesmo havendo uma redução na representatividade do PIB agropecuário no PIB Nacional nos anos de 2012 a 2016 (IBGE, 2017), a cadeia produtiva do agronegócio é significativamente importante e essencial ao desenvolvimento econômico.

Para Araújo (2013), os agentes da cadeia do agronegócio, podem ser classificados como os setores: a) "antes da porteira": empresas fornecedoras de insumos ou serviços, como propósito produtivo nas atividades agropecuárias (fazendas), exemplo: máquinas e implementos, insumos, corretivos, defensivos, sementes, tecnologia, financiamento, entre outras; b) "dentro da porteira": é tido como a atividade agropecuária, assim entendida como um conjunto de atividades, na propriedade (as fazendas), de característica intrínseca de preparo e manejo de solos, irrigação, colheita, tratos culturais, criações, entre outras; e, c) "após a porteira": adjacente do produto da atividade 
agropecuária, preponderantemente decorrente de atividades de industrialização, armazenamento, distribuição, consumo de produtos alimentares, fibras e produtos energéticos - provenientes da biomassa.

Esses agentes da cadeia produtiva do agronegócio, possuem características empresariais, as quais, segundo Aguiar e Resende (2013), o produtor rural precisa assumir o compromisso de empreendedor, conhecer a atividade na qual está trabalhando e fazer uso de novas formas de gerenciamento da propriedade através das tecnologias da informação para que se tornem produtivas e rentáveis. O papel destas tecnologias é essencial ao desenvolvimento da agricultura, pois permite aos produtores acesso a diversos conteúdos, em diferentes níveis de conhecimento, o qual evita privações, como o próprio isolamento das comunidades rurais (SILVEIRA; SCHWARTZ, 2011).

Essas tecnologias podem servir também de alternativas ao produtor rural contribuindo com a disponibilização de informações de interesse direto para os atores desta cadeia produtiva, ora instruindo, ora reduzindo a assimetria de informações entre o produtor e o mercado (AFFONSO et al., 2015).

A introdução e utilização das tecnologias de informação nas propriedades rurais facilita a busca por soluções e a ampliação do conhecimento dos produtores, possibilitando resultados econômicos e sociais na propriedade (ARTUZO et al., 2016).

Assim sendo, a tecnologia da informação pode ser compreendida pelos produtores rurais como um recurso de apoio a gestão e comunicação dentro do setor rural como um fator importante na tomada de decisões, proporcionando um apoio concomitante no desenvolvimento sustentável da propriedade (BERNARDES et al., 2015).

Além disso, a tecnologia da informação possui potencial para auxiliar o produtor rural nas tomadas de decisão de seu negócio, com a mudança da concepção dos processos, a partir de sua informatização e geração de relatórios gerenciais (FERRAZ; PINTO, 2017).

Muito embora a tecnologia da informação seja uma ferramenta disponível para auxiliar na diversificação de informações, carece ainda de constante atualização 
tecnológica para que os produtores não dependam somente de dados históricos e assim possam realizar projeções futuras (LIZZONI et al., 2018).

Nos últimos anos, a utilização da tecnologia da informação tem mostrado resultados positivos, desafios a serem superados e quebra de paradigmas na gestão em empreendimentos rurais. Alguns estudos contribuem neste sentido, como observado no Quadro 1, a seguir descrito.

Quadro 1 - Estudos e conclusões sobre a utilização da tecnologia da informação em empreendimentos rurais.

\begin{tabular}{|c|c|c|}
\hline Estudos & Conclusão & Autores \\
\hline $\begin{array}{l}\text { Informação e gestão na agri- } \\
\text { cultura familiar da região Oeste } \\
\text { de Santa Catarina }\end{array}$ & $\begin{array}{l}\text { Identificou que as práticas de } \\
\text { gestão estão associadas positi- } \\
\text { vamente com as propriedades } \\
\text { que possuem maior receita mo- } \\
\text { netária das atividades agrícolas } \\
\text { e pecuárias com utilização das } \\
\text { TI. }\end{array}$ & $\begin{array}{l}\text { SIMIONI; } \quad \text { BINOTTO } \\
\text { BATTISTON (2015) }\end{array}$ \\
\hline $\begin{array}{l}\text { O uso das tecnologias de infor- } \\
\text { mação e comunicação na agri- } \\
\text { cultura familiar: um caminho } \\
\text { para a sustentabilidade }\end{array}$ & $\begin{array}{l}\text { Embora a TI não seja utilizada na } \\
\text { sua totalidade, } 54 \% \text { dos produz- } \\
\text { tores rurais que adotaram, com- } \\
\text { preendem a importância do seu } \\
\text { uso como recurso de apoio a } \\
\text { gestão e comunicação do setor } \\
\text { rural. }\end{array}$ & $\begin{array}{l}\text { BERNARDES; VIEIRA; BONFIM } \\
\text { e SANT'ANA (2015) }\end{array}$ \\
\hline $\begin{array}{l}\text { Utilização da tecnologia de infor- } \\
\text { mação em propriedades rurais: } \\
\text { um caso no município de Getúlio } \\
\text { Vargas (RS) }\end{array}$ & $\begin{array}{l}\text { O principal motivo das proprie- } \\
\text { dades (entre } 91 \text { a } 120 \text { ha) que } \\
\text { não utilizam a TI é a falta de in- } \\
\text { formação. Das propriedades } \\
\text { com área menor de } 30 \text { ha que } \\
\text { usam elencam como estímulo } \\
\text { para crescimento. }\end{array}$ & $\begin{array}{l}\text { ARTUZO; JANDREY; KALSING } \\
\text { da SILVA e da SILVA (2016) }\end{array}$ \\
\hline $\begin{array}{l}\text { Sistemas de informação como } \\
\text { ferramenta de apoio à diversi- } \\
\text { ficação rural }\end{array}$ & $\begin{array}{l}\text { Os produtores utilizam a internet } \\
\text { para notícias da área rural, bus- } \\
\text { ca de preços, compras e vendas } \\
\text { online, mas destacam dificul- } \\
\text { dades no planejamento finan- } \\
\text { ceiro. Os que utilizam sistema de } \\
\text { informação relatam carência na } \\
\text { atualização do software (obso- } \\
\text { leto). }\end{array}$ & $\begin{array}{l}\text { LIZZONI; FEIDEN e FEIDEN } \\
(2018)\end{array}$ \\
\hline
\end{tabular}

Fonte: Elaborado pelo autor. 


\subsection{Ferramentas de gestão e acesso à rede de computadores para empreendimentos rurais}

Estudo realizados por (ABES, 2019) sinalizou uma tendência crescente no mercado Brasileiro de tecnologia da informação, incluindo hardware, software, serviços e exportações de tecnologias da informação, o qual movimentou 46,6 bilhões de dólares em 2018, colocando o País em posição de destaque na América do Sul - Figura 4.

Figura 4 - Mercado Brasileiro de Software - Panorama e Tendências - 2019 (América do Sul)

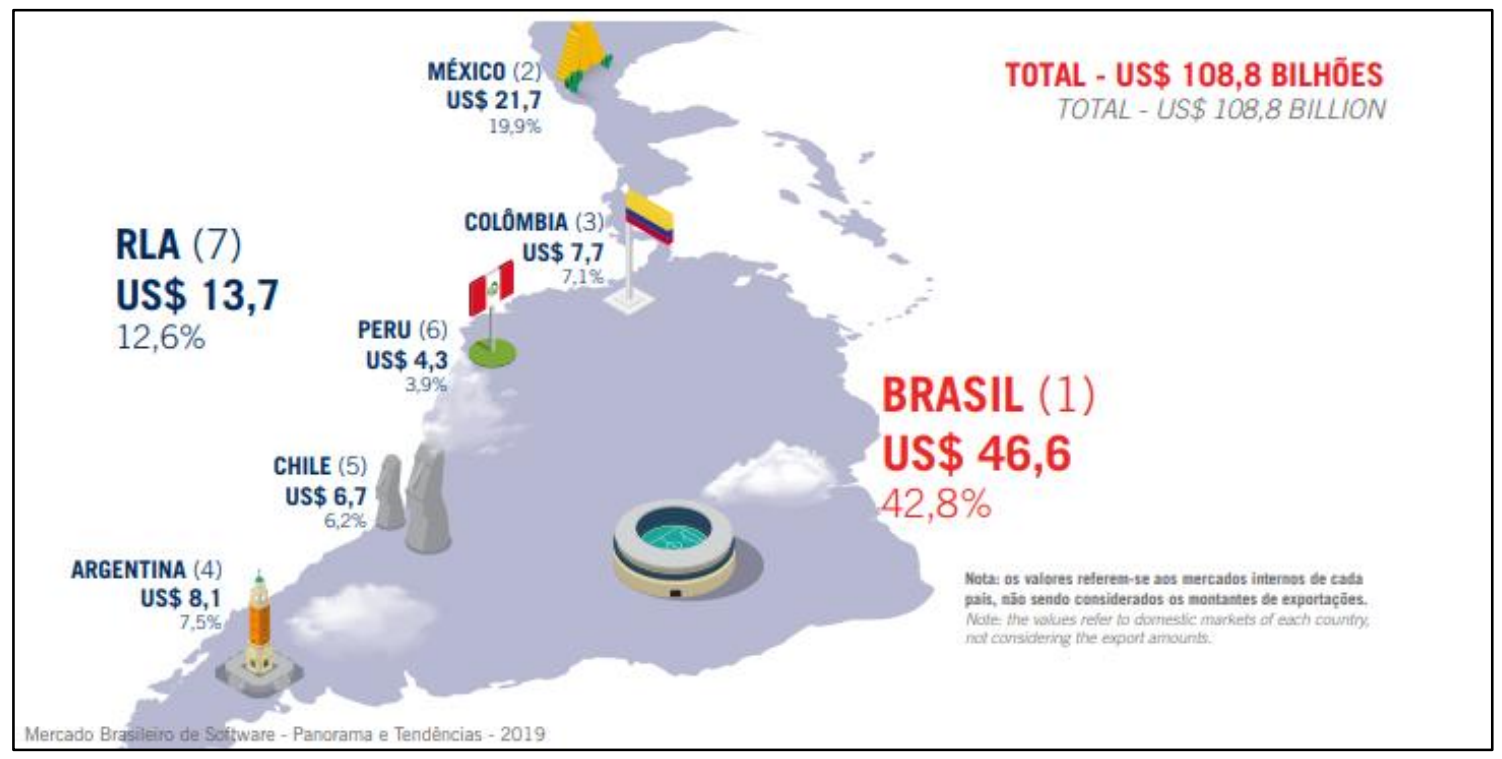

Fonte: ABES, 2019.

Considerando cenário mundial de US\$2.234 bilhões em movimento no segmento de tecnologia da informação, o Brasil ocupa a 9a posição, com liderança dos USA, seguido pela China e Japão, como observado na Figura 5. 
Figura 5 - Mercado Brasileiro de Software - Panorama e Tendências - 2019 (Cenário Global)

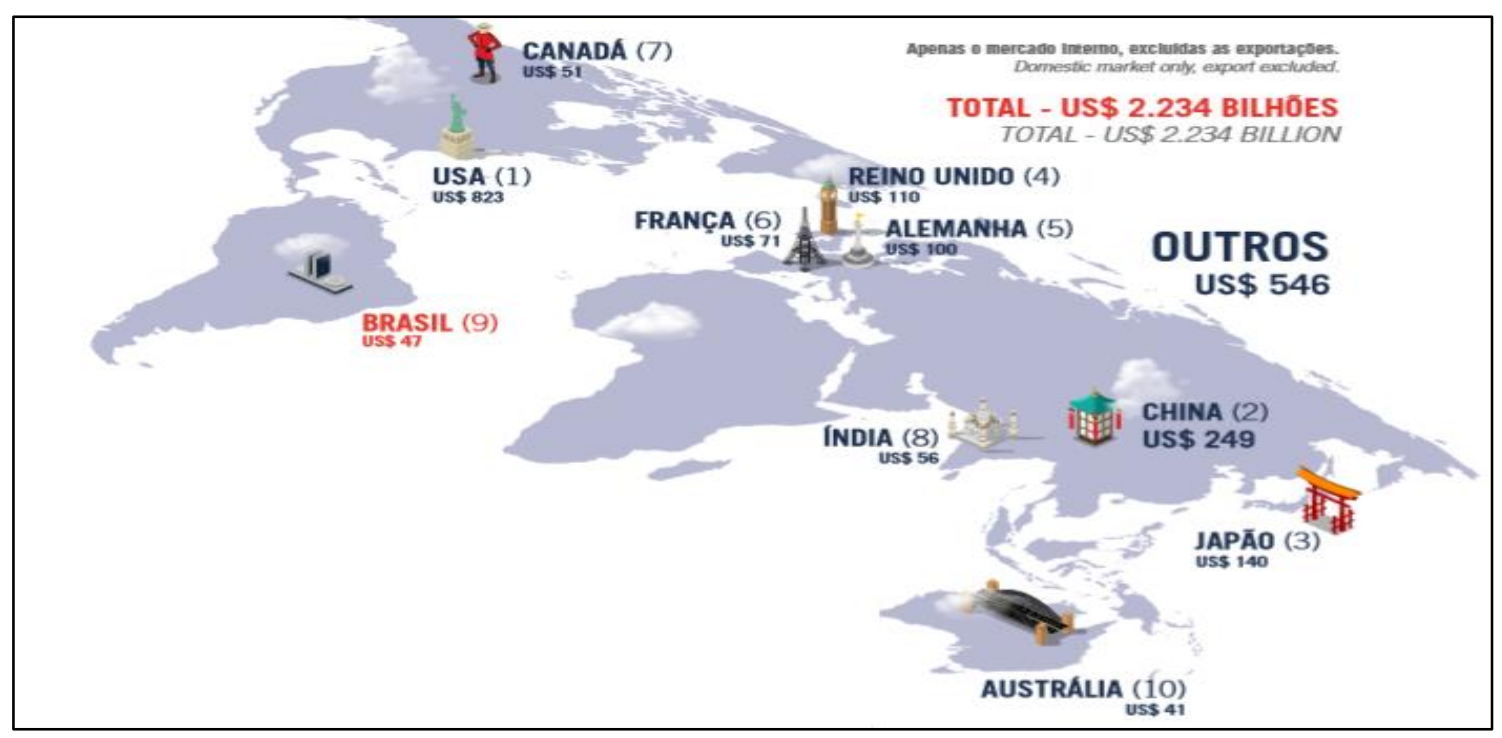

Fonte: ABES, 2019.

Especificamente, no que tange ao montante movimentado no mercado Brasileiro de software - US\$10.479 milhões, serviços - US\$12.262 milhões e hardwares - US\$ 23.896 milhões, há uma forte concentração na região Sudeste que detém cerca de 60,4\% do mercado, seguido pela região Sul 13,3\%, Centro-Oeste $11,7 \%$, Nordeste 10,2\% e Norte com 4,4\%, como se observa no Quadro 2.

Quadro 2 - O mercado nacional de tecnologia da informação - 2018 (US\$ Milhões)

\begin{tabular}{|c|c|c|c|c|}
\hline Região & Software & Serviços & Hardware & Total \\
\hline Norte & $2,80 \%$ & $3 \%$ & $5,90 \%$ & $4,40 \%$ \\
\hline Nordeste & $7,50 \%$ & $8,30 \%$ & $12,40 \%$ & $10,20 \%$ \\
\hline Centro-Oeste & $11,90 \%$ & $15,70 \%$ & $9,50 \%$ & $11,70 \%$ \\
\hline Sul & $13,20 \%$ & $12,90 \%$ & $13,60 \%$ & $13,30 \%$ \\
\hline Sudeste & $64,60 \%$ & $60,10 \%$ & $58,60 \%$ & $60,40 \%$ \\
\hline
\end{tabular}

Fonte: ABES, 2019.

No mercado de software no contexto mundial, verifica-se uma receita de aplicações corporativas totalizando mais de US\$193,6 bilhões em 2018. O CRM - segmento software de gestão de clientes, cresceu 15,6\%, movimentando US $\$ 48,2$ bilhões em 2018 (CRYPTO 
ID, 2019). Este segmento de softwares de gestão de relacionamento de clientes tem forte presença de grandes players, como observado no Quadro 3.

Quadro 3 - Receita total de software de CRM, por fornecedor, no Mundo em 2018 (em Dólares)

\begin{tabular}{|c|c|c|c|c|}
\hline Companhia & Vendas - 2018 & $\begin{array}{c}\text { Participação de } \\
\text { Mercado - 2018 } \\
(\%)\end{array}$ & Vendas - 2017 & $\begin{array}{c}\text { Participação de } \\
\text { Mercado - 2017 } \\
(\%)\end{array}$ \\
\hline Salesforce & US\$ 9,4 bilhões & $19,60 \%$ & US\$ 7,6 bilhões & $18,30 \%$ \\
\hline SAP & US\$ 4,0 bilhões & $8,30 \%$ & US\$ 3,4 bilhões & $8,30 \%$ \\
\hline Oracle & US\$ 2,6 bilhões & $5,50 \%$ & US\$ 2,4 bilhões & $6,00 \%$ \\
\hline Adobe & US\$ 2,4 bilhões & $5,10 \%$ & US\$ 2,0 bilhões & $4,80 \%$ \\
\hline Microsoft & US\$ 1,3 bilhões & $2,70 \%$ & US\$ 1,1 bilhões & $2,70 \%$ \\
\hline Outras & US\$ 28,3 bilhões & $58,80 \%$ & US\$ 24,9 bilhões & $59,90 \%$ \\
\hline Total & US\$ 48,2 bilhões & $100 \%$ & US\$ 41,7 bilhões & $100 \%$ \\
\hline
\end{tabular}

Fonte: CRYPTO ID, 2019.

Na segmentação dos principais mercados Brasileiros de software, os aplicativos e infraestrutura e segurança apresentaram um crescimento na ordem de $16,8 \%$ entre os períodos de 2017/2018, seguido de ambientes de desenvolvimento $12,7 \%$ e produção local para exportação de $3,1 \%$, perfazendo um crescimento médio anual de $14,7 \%$ entre 2017/2018, como se observa no Quadro 4.

Quadro 4 - Segmentação dos principais mercados Brasileiro de software

\begin{tabular}{|c|c|c|c|}
\hline Segmento & Volume & Participação & $2018 / 2017$ \\
\hline Aplicativos & 3.426 & $32,10 \%$ & $+16,8 \%$ \\
\hline Ambientes de Desenvolvimento & 4.801 & $44,90 \%$ & $+12,7 \%$ \\
\hline Insfraestrutura e Segurança & 2.252 & $21,10 \%$ & $+16,8 \%$ \\
\hline Produção Local para Exportação & 200 & $1,90 \%$ & $+3,1 \%$ \\
\hline Subtotal Software & 10.679 & $100 \%$ & $+14,7 \%$ \\
\hline
\end{tabular}

Fonte: ABES, 2019.

Aponta ainda (ABES, 2019) um mercado promissor e ainda com forte potencial de crescimento por usuários de software, principalmente no segmento da agroindústria, que apresenta uma tímida participação de 1,7\% em relação ao demais segmentos o que 
representa cerca de 201 usuários frente a 11.677 dos demais segmentos - período de 2017/2018, como se observa no Quadro 5.

Quadro 5 - Segmentação dos principais mercados usuários de software $\left(^{*}\right)$

\begin{tabular}{|c|c|c|c|}
\hline Segmento & Volume & Participação & $2018 / 2017$ \\
\hline Finanças & 2.899 & $30,70 \%$ & $+9,4 \%$ \\
\hline Serviços e Temecom & 2.882 & $24,10 \%$ & $+0,3 \%$ \\
\hline Indústria & 2.345 & $19,10 \%$ & $-0,3 \%$ \\
\hline Comércio & 1.652 & $11,90 \%$ & $+1,2 \%$ \\
\hline Governo & 504 & $3,70 \%$ & $-0,9 \%$ \\
\hline Óleo e Gás & 403 & $3,30 \%$ & $0 \%$ \\
\hline Agroindústria & 201 & $1,70 \%$ & $0 \%$ \\
\hline Outros & 791 & $5,50 \%$ & $+0,6 \%$ \\
\hline Total & 11.677 & $100 \%$ & $+2,9 \%$ \\
\hline
\end{tabular}

$\left(^{*}\right)$ Nota: nesta tabela estão considerados os valores relativos ao software de produção local, desenvolvido no exterior e sob encomenda.

Fonte: ABES, 2019.

MENDES et al. (2011) evidenciaram, em pesquisa realizada com 162 empresas desenvolvedoras e ofertantes de software, que há preponderância na oferta de software rural para a área animal (Tabela 4) e, quando desagregada por área de aplicação, destacam-se os segmentos bovinos de corte e leite (Tabela 5).

Tabela 4 - Percentual de software rural ofertado, por categoria (2011).

\begin{tabular}{lcc}
\hline Categoria & Número de indicações & \% do total de respostas \\
\hline Administração/Gerenciamento & 467 & 40,9 \\
Manejo animal & 235 & 20,6 \\
Cultivo vegetal & 155 & 13,6 \\
Controle de processo e/ou de & 286 & 25,0 \\
atividades rurais & 1143 & 100 \\
\hline Total & & \\
\hline
\end{tabular}

${ }_{1}^{1}$ Permite respostas múltiplas.

Fonte: MENDES et al. (2011). 
Tabela 5 - Softwares ofertados para o agronegócio, por áreas de aplicação na categoria Manejo Animal.

\begin{tabular}{lcc}
\hline Área de aplicação & Número de indicações $^{1}$ & \% da área de aplicação \\
\hline Bovinos de corte & 53 & 22,6 \\
Bovinos de leite & 45 & 19,2 \\
Suínos & 31 & 13,2 \\
Aves & 19 & 8,1 \\
Ovinos & 19 & 8,1 \\
Bubalinos & 18 & 7,7 \\
Caprinos & 18 & 7,7 \\
Equídeos & 15 & 6,4 \\
Peixes & 9 & 3,8 \\
Frutos do mar & 6 & 2,6 \\
Abelhas & 2 & 0,9 \\
\hline Total & 235 & 100 \\
\hline
\end{tabular}

${ }_{1}^{1}$ Permite respostas múltiplas.

Fonte: MENDES et al. (2011).

Fazendo um paralelo de outro País com o contexto brasileiro, verifica-se através do Departamento de Agricultura dos Estados Unidos - USAD (2019), que há 2.050.240 propriedades rurais nos Estados Unidos, sendo que $71 \%$ possuem acesso à internet, $73 \%$ possuem acesso a computadores e $47 \%$ o utilizam para fazer negócios.

Neste sentido, a aplicação das TIC's nos países da Europa e nos Estados Unidos, nos períodos de 1999 à 2013, tornou-se motivo de pesquisa para $\operatorname{GELB}(2012,2013)$ que reuniu diversos estudos através de aplicação de um questionário junto a especialistas em agroinformática - participantes dos Congressos bienais da European Federation Information Technologies in Agriculture, Food and Environment - EFITA. A pesquisa revela que a produção agrícola é de suma importância e as TIC's podem ajudar em inovação, mas ambas carecem de financiamento público, práticas de treinamento entre outros gargalos de utilização. No Quadro 6, é possível verificar que a adoção da tecnologia da informação como um problema permanente e reconhecido na Europa. Os problemas reconhecidos e aceitos tornam-se evidentes no Quadro 7: inabilidade em usar TIC, aspectos de infraestrutura, custo e falta de treinamento. 
Quadro 6 - A adoção de TIC ainda é um problema e o financiamento público para os Serviços Agrícolas de TIC justifica? (\% de respostas "Sim").

\begin{tabular}{|c|c|c|c|c|c|c|c|}
\hline & $\begin{array}{c}\text { Montpellier } \\
\text { (França) } \\
2001\end{array}$ & $\begin{array}{c}\text { Debrecen } \\
\text { (Hungria) } \\
2003\end{array}$ & $\begin{array}{c}\text { Villa Real } \\
\text { (Portugal) } \\
2005\end{array}$ & $\begin{array}{c}\text { Glasgow } \\
\text { (Escócia) } \\
2007\end{array}$ & $\begin{array}{c}\text { Wageningen } \\
\text { (Países Baixos) } \\
2009\end{array}$ & $\begin{array}{c}\text { Praga } \\
\text { (Rep. Tcheca) } \\
2011\end{array}$ & $\begin{array}{c}\text { Torino } \\
\text { (Itália) } \\
2013\end{array}$ \\
\hline 1 & 72.0 & 72.5 & 96.7 & 94.4 & 90.3 & 90.0 & 78.9 \\
\hline 2 & 67.8 & 84.2 & 88.1 & 88.2 & 77.4 & $>90.0$ & 80.7 \\
\hline
\end{tabular}

1- Existem problemas com a absorção de TIC na agricultura?

2- O financiamento público para serviços de TIC para agricultura é justificado?

Fonte: GELB (2012, 2013).

Quadro 7 - Quais são os fatores que limitam o uso de TIC pelos agricultores (\% de respostas "Sim").

\begin{tabular}{|c|c|c|c|c|c|c|c|}
\hline & $\begin{array}{c}\text { Montpellier } \\
\text { (França) } \\
2001\end{array}$ & $\begin{array}{c}\text { Debrecen } \\
\text { (Hungria) } \\
2003\end{array}$ & $\begin{array}{c}\text { Villa Real } \\
\text { (Portugal) } \\
2005\end{array}$ & $\begin{array}{c}\text { Glasgow } \\
\text { (Escócia) } \\
2007\end{array}$ & $\begin{array}{c}\text { Wageningen } \\
\text { (Países Baixos) } \\
2009\end{array}$ & $\begin{array}{c}\text { Praga } \\
\text { (Rep. Tcheca) } \\
2011\end{array}$ & $\begin{array}{c}\text { Torino } \\
\text { (Itália) } \\
2013\end{array}$ \\
\hline 1 & 29.3 & 5.9 & 45.0 & 12.5 & 45.2 & $<45.0$ & 56.1 \\
\hline 2 & - & 19.6 & 35.0 & 28.6 & 23.8 & 0.0 & 21.0 \\
\hline 3 & 32.3 & 39.2 & 23.0 & 42.2 & 29.0 & $<25.0$ & 19.3 \\
\hline 4 & 16.9 & 35.3 & 16.7 & 17.9 & 58.0 & $>65.0$ & 54.3 \\
\hline
\end{tabular}

1-incapacidade de usar as TICs; 2-problemas de infraestrutura; 3-custos; 4-falta de treinamento.

Fonte: GELB $(2012,2013)$.

Verifica-se, que a referida pesquisa, em comparação aos períodos anteriores, há preponderância nos problemas com a adoção das TICs pela falta de treinamento e ou incapacidade de usar. Por outro, os problemas de infraestrutura e de custos parecem resolvidos. Para Far e Moghaddam (2018), tecnologia da informação na agricultura, denominadas como de precisão, proporcionam um desenvolvimento sustentável, de baixo insumo e alto rendimento agricultura. Assim, seus impactos técnicos proporcionam aumento de produtividade, qualidade dos produtos e melhorias nas condições operacionais de propriedades agrícolas. Neste sentido, muitos países têm utilizado a agricultura de precisão como uma opção altamente imprescindível para planejamento e enfrentamento de pragas, onde o uso de técnicas e sistemas agrícolas modernos conseguem detectar e prevenir que safras sejam afetadas por diferentes doenças (BHANGE; HINGOLIWALA, 2015). 
Esse movimento tem proporcionado o uso da tecnologia da informação na área de sensores inteligentes, como a exemplo, o uso de drones na agricultura, como forma de rastreamento para detectar crimes florestais e ou melhor qualidade da colheita (PURI et al., 2017). Se a adoção das tecnologias da agricultura de precisão se tornarem mais fáceis de implementar, elas podem aumentar os lucros para os produtores e com benefícios ambientais. Neste sentido, diversos estudos têm contribuído aos produtores de milho dos EUA em adaptar ao uso destas tecnologias, de forma a ajudar, também, numa futura política agrícola para o segmento (SCHIMMELPFENNIG, 2016). Para que as tecnologias possam ter utilidade na agricultura de precisão há necessidade de investimentos. No contexto brasileiro há previsibilidade de diversas linhas de crédito para investimentos em melhorias e ampliação das TICs, na ordem de $R \$ 40,0$ bilhões: Moderfrota, Programa ABC, Programa PCA, Inovagro, Pronamp, Moderinfra, Modeagro e Prodeccop (MAPA, 2018), contudo, constata-se a ausência em investimentos de acesso à rede de computadores para empreendimentos rurais por parte do Governo.

Segundo a ANATEL (2018), a legislação Brasileira prevê cobertura de internet em um raio de 30 quilômetros dos limites da sede municipal mais próxima, o que faz com as áreas rurais tenham como primeira e, na maioria das situações, a telefonia fixa como uma das únicas soluções de comunicação. Para a ABDI (2018), há muitos gargalos de internet no Brasil, em especial, na agricultura que tem sido carro-chefe na retomada do crescimento econômico nacional. A associação afirma ainda que para utilizar o potencial no campo, alguns centros de pesquisas estão apostando em inovação em TICs, como pode se observar no Quadro 8.

Com o intuito de levar a conectividade de banda larga para áreas rurais e remotas, - CPqD desenvolveu aplicações de TICs para a agricultura e outros segmentos da economia, sobretudo através da tecnologia LTE (tecnologia desenvolvida pelo centro) que viabiliza aplicações de loT (internet das coisas) e promove o desenvolvimento sustentável (CPqD, 2018). 
Quadro 8 - Centros de pesquisas e algumas das soluções de TICs no agronegócio brasileiro.

\begin{tabular}{|c|l|l|l|l|}
\hline $\begin{array}{c}\text { Centros } \\
\text { de } \\
\text { Pesquisa }\end{array}$ & Soluções Tecnológicas & $\begin{array}{c}\text { Segmentos } \\
\text { do } \\
\text { Agronegócio }\end{array}$ & \multicolumn{1}{c|}{$\begin{array}{c}\text { Comunicações e } \\
\text { Conectividades }\end{array}$} & $\begin{array}{c}\text { Parceiros } \\
\text { Incentivo ou } \\
\text { Apoio }\end{array}$ \\
\hline CPqD & $\begin{array}{l}\text { Sensoriamento e rastrea- } \\
\text { bilidade, georreferencia- } \\
\text { mento, processamento de } \\
\text { fala, segurança, sistemas } \\
\text { de energia entre outras. }\end{array}$ & $\begin{array}{l}\text { Sucroenergéti } \\
\text { co, grãos, flo- } \\
\text { resta e pecuá- } \\
\text { ria. }\end{array}$ & $\begin{array}{l}\text { Rádio Base (eNode B) - } \\
\text { LTE, terminais veiculares, } \\
\text { serviço limitado privado } \\
\text { (LSP) com uso do 4G, fi- } \\
\text { bra óptica e outras redes } \\
\text { móveis. }\end{array}$ & $\begin{array}{l}\text { BNDES, } \\
\text { FUNTTEL, } \\
\text { EMBRAPII }\end{array}$ \\
\hline EMBRAPA & $\begin{array}{l}\text { Observatório de tendên- } \\
\text { cias, análise de estudos, } \\
\text { estratégias para plano de } \\
\text { ação }\end{array}$ & $\begin{array}{l}\text { Agrícola e pe- } \\
\text { cuária }\end{array}$ & & $\begin{array}{l}\text { LABEX, Minis- } \\
\text { térios das Câ- } \\
\text { maras Setori- } \\
\text { ais e equipe in- } \\
\text { terna }\end{array}$ \\
\hline
\end{tabular}

Fonte: Adaptado de CPqD (2018, 2019); EMBRAPA (2019).

Em contexto similar, a EMBRAPA criou o sistema denominado Agropensa, que em suma, tem o objetivo de produzir e difundir conhecimentos aplicados a atividade rural. Este projeto conta com uma equipe de 9.713 empregados, 7 áreas administrativas, 42 unidades descentralizadas em todas as regiões do Brasil, 4 laboratórios virtuais no Exterior (LABEX) e 3 escritórios na América Latina e África.

Ambos os centros de pesquisa (CPqD e EMBRAPA) apontam para a necessidade do uso das TICs, seja para comunicação, acesso a base de informações ou na melhoria da gestão produtiva.

Outras instituições de ensino e pesquisa, como a exemplo Universidade de São Paulo - USP, através da Faculdade de Zootecnia e Engenharia de Alimentos - FZEA, através do Programa de Pós-Graduação em Gestão e Inovação na Indústria Animal (GIIA) têm se empenhado em propor soluções tecnológicas ao agronegócio brasileiro (Quadro 9). 
Quadro 9 - Soluções tecnológicas aplicadas ao agronegócio brasileiro - Programa GIIA

\begin{tabular}{|l|l|l|}
\hline \multicolumn{1}{|c|}{ Proposta Tecnológica } & \multicolumn{1}{|c|}{ Objetivo da pesquisa } & Autores \\
\hline $\begin{array}{l}\text { Veículo aéreo não tripulado de asa } \\
\text { fixa no monitoramento e coleta de } \\
\text { imagem de animais e ambientes em } \\
\text { propriedades rurais }\end{array}$ & $\begin{array}{l}\text { Apontar possíveis viabilidades } \\
\text { financeiras e operacionais, com a } \\
\text { finalidade de monitorar propriedades } \\
\text { rurais, animais e área de plantio, } \\
\text { permitindo auxiliar os gestores nas } \\
\text { tomadas de decisões. }\end{array}$ & TEIXEIRA (2016) \\
\hline $\begin{array}{l}\text { Desenvolvimento de sistema } \\
\text { automatizado de monitoramento de } \\
\text { ambientes de produção animal, } \\
\text { utilizando uma rede de sensores } \\
\text { sem fio }\end{array}$ & $\begin{array}{l}\text { Implementar e testar uma rede de } \\
\text { sensores ZigBee® para monitoração } \\
\text { de umbiente experimental de } \\
\text { produção de frangos de corte. }\end{array}$ & OLIVEIRA (2016) \\
\hline $\begin{array}{l}\text { Uso de sensor efeito Hall para } \\
\text { medição da vazão de fluidos no } \\
\text { processo de produção de } \\
\text { palatabilizantes à base de proteína } \\
\text { animal em escala piloto }\end{array}$ & $\begin{array}{l}\text { Propor uma solução ao problema de } \\
\text { medir a vazão em tempo real e à falta } \\
\text { de medidores de vazão com } \\
\text { capacidade de atender necessidades } \\
\text { na indústria }\end{array}$ & HORIGOSHI (2016) \\
\hline
\end{tabular}

Fonte: Elaborado pelo autor.

Assim, as inovações tecnológicas, principalmente na área da informática, ampliam as oportunidades de se empreender nesse mercado, por oferecerem uma maior interação e possibilidade de adoção de recursos tecnológicos pelos agricultores (LAMPERT et al., 2015). Essa interação permite utilizar ferramentas de apoio a gestão nos empreendimentos rurais, assim entendidos como sistema de informação, cujo foco é de flexibilizar informações não estruturadas (PADOVEZE, 2011).

Essa tendência, pode ser viabilizada pela aplicação de simples planilhas de controle, com alimentação de dados manual, que são indispensáveis para a tomada de decisão (AGUIAR; RESENDE, 2013). Assim, para os gestores, não basta apenas saber o que aconteceu no passado, mas gerir seu negócio em tempo real, pois as decisões visam gerenciar principalmente aquilo que está por acontecer (VIEIRA et al., 2015). 
Não obstante, torna-se imprescindível o uso de software, o qual irá alicerçar as decisões vividas pelos gestores nos empreendimentos rurais (O'BRIEN, 2011) nas modalidades de: a) Aplicativo: executa tarefas de processamento de informações para usuários finais; ou b) Software: gerencia e apoia operações de sistemas de redes de computadores.

Neste sentido, a coleta de dados, gestão e análise das informações, tomada de decisão, monitoramento e controle das decisões norteiam o processo de gestão nos empreendimentos rurais, os quais diminuem incertezas (LEMOS, 2015).

Quadro 10 - Ferramentas de gestão combinadas ou não ao uso de software em empreendimentos rurais.

\begin{tabular}{|c|c|c|c|}
\hline Ferramentas de gestão & $\begin{array}{l}\text { Resumo dos resultados } \\
\text { obtidos ou observados }\end{array}$ & $\begin{array}{l}\text { Atividade e } \\
\text { Localidade }\end{array}$ & Autores \\
\hline $\begin{array}{l}\text { Matriz GUT, brainstorming, } \\
\text { Diagrama de Ishikawa, Ciclo } \\
\text { PDCA, 5W2H }\end{array}$ & $\begin{array}{l}\text { Medicamentos vencidos, bebe- } \\
\text { douros sujos, presença de do- } \\
\text { ença de casco, ausência de } \\
\text { calendário sanitário dentre } \\
\text { outras. }\end{array}$ & $\begin{array}{l}\text { Atividade: Leiteira } \\
\text { Localidade: Sul de } \\
\text { Minas Gerais }\end{array}$ & $\begin{array}{l}\text { LOPES et al. } \\
(2016)\end{array}$ \\
\hline $\begin{array}{l}\text { Contabilidade de Custos: } \\
\text { capitais físicos postos à dis- } \\
\text { posição, animais vivos, custo } \\
\text { médio de venda do leite, valo- } \\
\text { res médios de alimentação } \\
\text { animal, cálculo médio de } \\
\text { produção e demonstração de } \\
\text { lucro ou prejuízo }\end{array}$ & $\begin{array}{l}\text { Descontinuidade dos controles } \\
\text { manuais de nascimento, perío- } \\
\text { do de gestação das matrizes e } \\
\text { quantidade de leite vendidos } \\
\text { ora realizado antes do óbito do } \\
\text { patriarca. Herdeiros identifica- } \\
\text { ram a realidade financeira da } \\
\text { propriedade (prejuízo) }\end{array}$ & $\begin{array}{l}\text { Atividade: Leiteira } \\
\text { Localidade: } \\
\text { Banabuiú - CE }\end{array}$ & $\begin{array}{l}\text { SILVA e } \\
\text { ANDRADE } \\
\text { (2016) }\end{array}$ \\
\hline $\begin{array}{l}60 \% \text { utilização controles ma- } \\
\text { nuais, } 12 \% \text { planilhas finan- } \\
\text { ceiras, } 8 \% \text { software de ges- } \\
\text { tão e controle e } 20 \% \text { ausên- } \\
\text { cia de ferramentas }\end{array}$ & $\begin{array}{l}\text { Baixa escolaridade dos gesto- } \\
\text { res, ausência de registros de } \\
\text { entradas e saídas de produtos e } \\
16 \% \text { ausência de investi- } \\
\text { mentos }\end{array}$ & $\begin{array}{l}\text { Atividade: Aves, leite, } \\
\text { gado bovino, leite in } \\
\text { natura, milho, soja e } \\
\text { outros } \\
\text { Localidade: Meio- } \\
\text { Oeste de Santa } \\
\text { Catarina }\end{array}$ & $\begin{array}{l}\text { FERNANDES } \\
\text { et al. (2018) }\end{array}$ \\
\hline
\end{tabular}

Fonte: Elaborado pelo autor. 
Desta forma, alguns autores relataram em suas pesquisas, ferramentas ora empregadas em diversos segmentos do agronegócio, por exemplo, como opções de necessidade ou possível interação com as tecnologias da informação com reflexos positivos na gestão dos empreendimentos rurais: controle de medicamentos vencidos, descontinuidade de controles paralelos ou manuais, possibilidade de mensuração do valor econômico ou financeiro para sucessores das propriedades, entre outros como observa-se no Quadro 10.

Observa-se, no trabalho de FONSECA et al. (2017), que em termos de ferramentas de gestão é possível gerenciar e analisar por meio de Indicadores de Sustentabilidade em Agroecossistemas - modelo ISA, o qual possibilita o balanço econômico e social, qualidade da água, manejo dos sistemas de produção, entre outras. Essa interatividade pode ocorrer por ferramentas denominadas WEB, o qual o software coleta, armazena, formata, valida e padroniza informações em banco de dados (O'BRIEN, 2011). Além de possibilitar gerenciar diversas propriedades ao mesmo tempo, ao gestor rural permite mensurar resultados através de indicadores de desempenho como observado no Quadro 11.

Quadro 11 - Resumo dos principais indicadores de desempenho atrelados ao uso de software.

\begin{tabular}{|l|l|}
\hline Indicadores de desempenho financeiros & Indicadores de desempenho não financeiros \\
\hline Prazo médio de estocagem, recebimento e paga- & Número de fornecedores x número de produtos \\
mento & $\begin{array}{l}\text { Volume de vendas x participação de mercado } \\
\text { Capacidade produtiva x tempo de fabricação de } \\
\text { Giro dos estoques e do ativo }\end{array}$ \\
Margem Operacional e Líquida & $\begin{array}{l}\text { umoduto. } \\
\text { Rentabilidade do Ativo e do Patrimônio. }\end{array}$ \\
Custo Operacional, direto e indireto. & pedido \\
\hline
\end{tabular}

Fonte: PADOVEZE, 2011.

Entre os indicadores citados no Quadro 12, ressalta-se o controle dos custos por meio do uso de software. Todo empreendimento rural possui gastos relativos as culturas desenvolvidas na propriedade com por exemplo: insumos, máquinas, equipamentos, 
animais, benfeitorias, tributos entre outras (AGUIAR; RESENDE, 2013). Esses custos podem ser explícitos ou implícitos, os quais representam os fatores utilizados para produzir determinado bem que devem ser remunerados, compreendendo-se entre eles: terra, capital e empresário (MATSUNAGA et al., p. 126, 1976).

Nesta vertente os custos podem ser entendidos e utilizados como uma ferramenta de apoio imprescindível nos empreendimentos rurais com conotação financeira e econômica. São divididos em: a) Custo Operacional Efetivo - COE: constituem dispêndios em dinheiro relativos aos insumos, operação mecânica, mão de obra, transportes, tributos, despesas financeiras, serviços de terceiros e despesas gerais empregados diretamente na atividade rural; b) Custo Operacional Total - COT: representa o total do custo operacional efetivo (COE) acrescidos pro labore e depreciações de equipamentos e infraestrutura e, c) Custo Total - CT: constitui a soma do custo operacional Efetivo (COE) + custo operacional total (COT) acrescido o custo oportunidade do capital e ou da terra. (MATSUNAGA et al., p. 126, 1976)

Feitas tais considerações e sendo, reconhecidamente, o agronegócio uma atividade fundamental para a economia no Brasil, a presente pesquisa pretende mostrar que todo empreendimento rural pode ser melhorado com a presença da tecnologia da informação.

Embora a rede mundial de computadores ainda não seja uma realidade para uma parcela das propriedades rurais produtoras brasileiras, carecendo-se de investimentos públicos que proporcionem a infraestrutura e treinamento aos usuários, é possivelmente através dela que a tecnologia pode oferecer diagnósticos para uma gestão administrativa menos empírica nas empresas rurais.

É preciso que se ressalte que as tecnologias da informação e comunicação vêm se destacando como uma ferramenta de coleta, armazenamento, análise e controle de dados com ampla utilização na área da gestão e controle de empresas. Contudo, sem conectividade ou com limitação na transmissão de dados é como "um barco à deriva do sabor dos ventos", não há como usufruir de seus benefícios. De acordo com o Censo do IBGE (2017) há uma parcela privada ao acesso à rede de computadores no Brasil, cerca 
de $28,19 \%$ dos estabelecimentos agropecuários possuem acesso à internet e estão distribuídos da seguinte forma (Tabela 6):

Tabela 6 - Estabelecimentos agropecuários por região (com e sem acesso à internet)

\begin{tabular}{lrcc}
\hline Regiões & \multicolumn{1}{c}{ Total } & Com acesso à internet & Sem acesso à internet \\
\hline Norte & 580.613 & 91.080 & 489.533 \\
Nordeste & 2.322 .719 & 505.726 & 1.816 .993 \\
Sudeste & 969.415 & 358.211 & 611.204 \\
Sul & 853.314 & 374.555 & 478.759 \\
Centro-Oeste & 347.263 & 100.584 & 246.679 \\
\hline Brasil & 5.073 .324 & 1.430 .156 & 3.643 .168 \\
\hline
\end{tabular}

Fonte: IBGE - Censo Agropecuário (2017).

Quando se compara a relação do número de estabelecimentos agropecuários com acesso à internet, por região, verifica-se que a região Sul possui mais de $43,89 \%$ de estabelecimentos com acesso à internet, seguido pelo Sudeste com $36,95 \%$, CentroOeste com $28,96 \%$, Nordeste com $21,77 \%$ e Norte com $15,69 \%$, perfazendo assim, um montante de 1.430.156 de estabelecimentos agropecuários com conectividade. Mesmo representando quase um terço do contingente, ainda há uma forte concentração de estabelecimentos sem acesso à internet na ordem de 3.643.168, com destaque na região Norte onde $84,31 \%$ estão privados ou com restrições ao acesso à rede de computadores no Brasil.

Além das premissas de estabelecimentos agropecuários com conectividade, outro aspecto muito importante é o tipo de velocidade praticada, que poderá impactar na lentidão ou rapidez no processamento das informações. Muito embora a pesquisa não tenha apontado aspectos de velocidade de upload e download pode-se observar as tecnologias usadas para conexão na Tabela 7. 
Tabela 7 - Tipos de conexão à internet nos estabelecimentos agropecuários

\begin{tabular}{lrrrrr}
\hline \multirow{2}{*}{ Tipo de conexão } & \multicolumn{5}{c}{ Região } \\
\cline { 2 - 6 } & \multicolumn{1}{c}{ Norte } & Nordeste & Sudeste & \multicolumn{1}{c}{ Sul } & Centro-Oeste \\
\hline Banda larga & 30.896 & 231.324 & 124.665 & 224.154 & 48.728 \\
Discagem por linha & 1.450 & 5.506 & 4.392 & 6.709 & 1.475 \\
Internet móvel & 63.357 & 313.138 & 278.490 & 193.547 & 60.849 \\
\hline Total & 95.703 & 549.968 & 407.547 & 424.410 & 111.052 \\
\hline
\end{tabular}

Fonte: IBGE - Censo Agropecuário (2017)

Verifica-se uma preponderância em todas as regiões pelo tipo de conexão internet móvel, salvo exceção a região Sul, onde o tipo de conexão com banda larga prevalece. Segundo FERREIRA et al. (2016), o dispositivo móvel representa grande oportunidade de negócios, além da grande variedade de serviços, como e-mails, acesso ao sistema bancário, jogos, dentre outros. Sua tecnologia é ofertada nas modalidades $3 G, 4 G$ e recentemente $5 \mathrm{G}$, os quais permitem diversas possibilidades de velocidades na transmissão de dados.

Em um grau de relevância não muito distante da internet móvel, verifica-se o uso da banda larga pelos estabelecimentos agropecuários. De acordo com LIMA (2017), a conexão de banda larga pode ter várias conotações técnicas e tratativas de uso e ou incentivo através de políticas públicas como o Programa Nacional de Banda Larga (PNBL), com objetivo de popularizar o acesso em todos os municípios do País, podendo sua velocidade variar entre $1 \mathrm{Mbps}$ à $350 \mathrm{Mbps}$, de acordo com as operadoras ofertantes deste serviço, bem como, sua relação preço versus velocidade. Este tipo de conexão pode ser distribuído aos domicílios e seus respectivos acessos por diversos tipos de tecnologias, como exemplo: xDSL, Cable Modem, FTTx, ATM, SATELITE entre outros, associados às estratégias de atuação e presença geográfica dos principais grupos que atuam no segmento de banda larga e telefonia fixa (LEANDRO, 2017).

Não menos relevante, a conexão de discagem por linha, vem gradativamente perdendo seu espaço por outras opções ofertadas pelas operadoras e essa tendência não é diferente nos estabelecimentos agropecuários como observado no Quadro 13. De acordo com TECHTUDO (2020), a conexão discada ou conexão dial-up era a mais 
utilizada entre os períodos de 1990 à 2000, antes da chegada da conexão de banda larga, o qual apresentava demora e quedas frequentes na conexão, lentidão no processamento de dados e custo elevado no pulso da linha telefônica. Esses tipos de conexões contribuem diretamente na velocidade de transmissão dos dados. De acordo com o CETIC (2018), tanto nos domicílios urbanos ou rurais, verifica-se conexões com velocidades que podem variar de 256 Kbps até 51 Mbps ou mais (Figura 6).

Figura 6 - Domicílios com acesso à internet, por velocidade e conexão

\begin{tabular}{|c|c|c|}
\hline \multicolumn{3}{|c|}{ - Urbana Rural } \\
\hline 51 MBPS OU MAIS & 1.658 .771 & 26.986 \\
\hline DE 21 MBPS A 50 MBPS & 2.719.707 & 41.103 \\
\hline DE 11 MBPS A 20 MBPS & 3.291 .201 & 70.357 \\
\hline DE 9 MBPS A 10 MBPS & 4.149 .524 & 144.674 \\
\hline DE 5 MBPS A 8 MBPS & 3.568 .603 & 225.862 \\
\hline DE 3 MBPS A 4 MBPS & 2.819 .666 & 281.767 \\
\hline $2 \mathrm{MBPS}$ & 2.828 .565 & 391.847 \\
\hline $1 \mathrm{MBPS}$ & 1.735 .756 & 395.880 \\
\hline DE 257 KBPS A 999 KBPS & 103.016 & 834 \\
\hline ATÉ 256 KBPS & 357.547 & 63.034 \\
\hline
\end{tabular}

Fonte: CETIC (2018)

Dos 1.678.344 domicílios rurais pesquisados, e que responderam a este quesito, $52,88 \%$ possuem conexão de baixa velocidade, sendo 5,95\% entre $256 \mathrm{Kbps}$ à $999 \mathrm{Kbps}$ e 46,93\% entre $1 \mathrm{Mbps}$ e $2 \mathrm{Mbps}$, um contraste, quando comparado aos domicílios urbanos que representa $21,63 \%$ do contingente. Para INTERNETLAB (2020), no que tange a política de banda larga, o Tribunal de Contas da União (TCU), através de análises sobre as ações governamentais, concluiu que um dos obstáculos a ser rompido é à inclusão digital - onde há existência de políticas públicas desconexas entre diferentes poderes, de níveis federativos, gera redundância na prestação de serviços digitais, falta de isonomia e desperdícios de recursos públicos, desprovendo o acesso aos mais necessitados. Ainda no âmbito rural, o JORNAL O ESTADÃO (2020) reforça que o 
desafio da conectividade no agro é a conexão nas zonas rurais, onde empresas tem um grande desafio em driblar a falta de internet no campo atrelado ao aumento de produtividade. Ressalta ainda, que $21 \%$ dos produtores rurais não acessam à rede por causa da indisponibilidade de sinal, como solução para esse problema: políticas públicas de incentivo as empresas de telefonia, linhas de créditos para o produtor financiar sua conectividade e parcerias público-privadas. Além dessas prerrogativas, outros fatorem contribuem para o baixo acesso à rede (Figura 7 ).

Figura 7 - Domicílios rurais sem acesso à internet, por principal motivo para a falta de internet

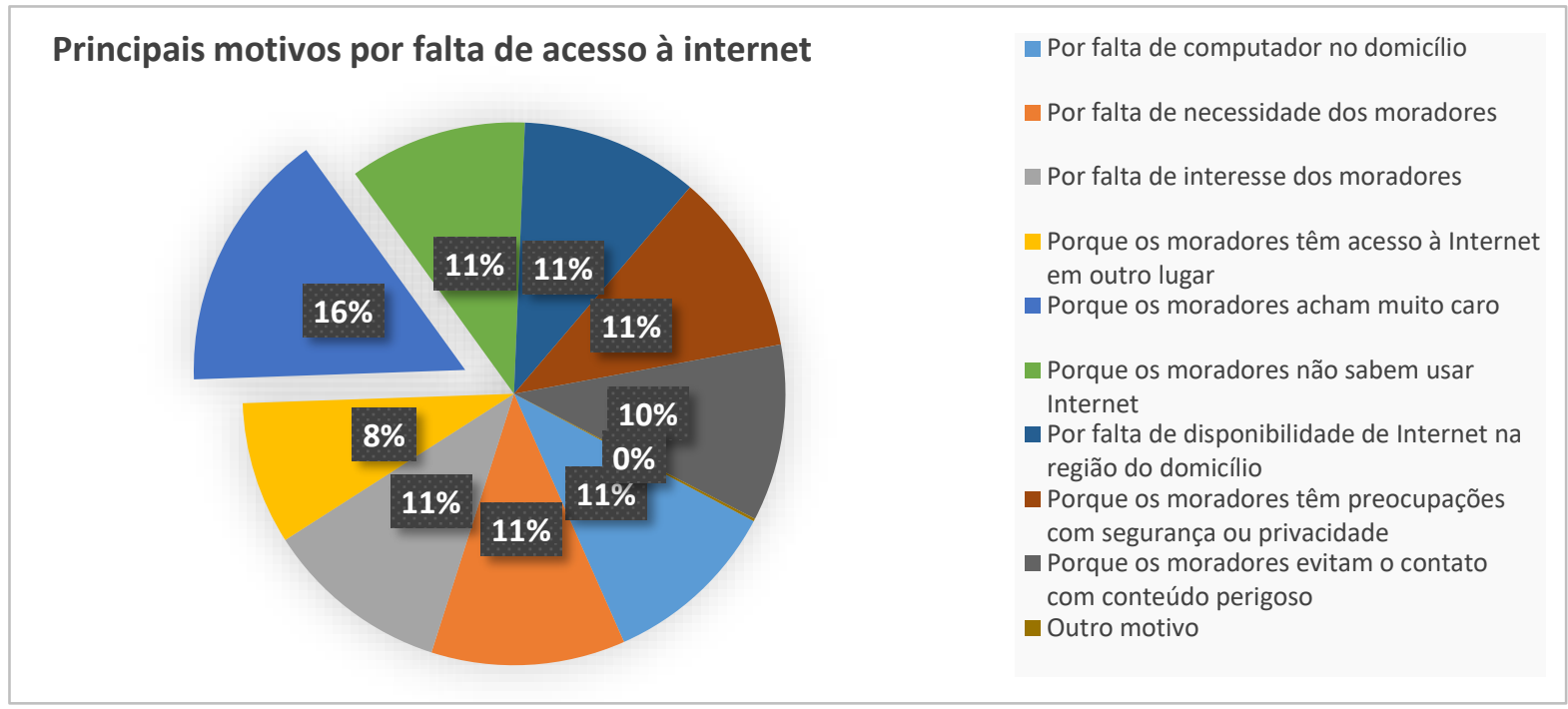

Fonte: CETIC (2018)

Aponta ainda CETIC (2018), que os principais motivos por falta de acesso à internet se concentram em: preço muito caro, falta de computador no domicílio, não sabem usar a internet, preocupações com segurança ou privacidade entre outras.

\subsection{Análise de correspondência simples}

Segundo HAIR et.al., (2005) a análise multivariada tem suas raízes das técnicas das análises univariadas e bivariadas e os métodos multivariados são escolhidos de acordo com os objetivos da pesquisa. Embora, às vezes, possa ser utilizada para confirmação dos eventos, sabe-se que a análise multivariada é uma análise exploratória 
de dados, prestando-se a gerar hipóteses e não tecer confirmações a respeito dos mesmos, o que seria uma técnica confirmatória, como nos testes de hipótese, nos quais se tem uma afirmação a respeito da amostra em estudo.

Dentre as inúmeras técnicas multivariadas disponíveis para o estudo simultâneo de variáveis numéricas, a Análise de Correspondência Simples (ACS) é uma técnica de análise voltada para o estudo de variáveis categóricas. Visa à determinação de um sistema de associação entre os elementos das linhas e colunas de uma tabela de contingência, buscando explicar uma possível estrutura de associação entre elas. A técnica foi formalizada por Benzécri (1973) para o estudo de tabelas de contingência em linguística, mas tem aplicabilidade em diversas áreas do conhecimento, como nas áreas de medicina, saúde e administração.

Para Hair et al. (2009, p. 507), a análise por correspondência apresenta três características interessantes que a distinguem de outras técnicas:

i. É uma técnica composicional e não decomposicional, porque o mapa perceptual é baseado em associação entre objetos e um conjunto de características descritivas ou atributos especificados pelo pesquisador.

ii. Sua aplicação mais direta é na retratação da correspondência de categorias de variáveis, particularmente aquelas categorias medidas em escalas nominais. Tal correspondência é, desse modo, a base para o desenvolvimento de mapas perceptuais.

iii. Os únicos benefícios da ACS residem em sua habilidade para representar a relação entre linhas e colunas, por exemplo, marcas e atributos, em um único espaço.

De acordo com GODOY (1995), a pesquisa que acrescenta informações qualitativas trata melhor a compreensão de um determinado fenômeno, no contexto em que ocorre e do qual é parte. Para tanto, o pesquisador deve ir a campo captar tal fenômeno, a partir da perspectiva das pessoas envolvidas, considerando os diferentes pontos de vistas, neste caso, vários tipos de dados são coletados e analisados para que se entenda a dinâmica deste fenômeno. 
Neste contexto, as entrevistas são fundamentais quando se deseja mapear práticas, crenças, valores e sistemas classificatórios de universos sociais específicos, mais ou menos bem delimitados, em que os conflitos e contradições não estejam claramente explicitados. Elas permitem ao pesquisador fazer uma espécie de mergulho em profundidade, coletando indícios dos modos como cada um daqueles sujeitos percebe e significa sua realidade e levantando informações consistentes que permitem descrever e compreender a lógica que preside as relações que se estabelecem no interior daquele grupo, o que, em geral, é mais difícil obter com outros instrumentos de coleta de dados (DUARTE, 2004).

Segundo ROSA e ARNOLDI (2006), em relação às outras técnicas de questionários, formulários, leitura documentada e observação participativa, as entrevistas apresentam vantagens que podem aqui ser evidenciadas:

- Permitem a obtenção de grande riqueza informativa - intensiva, holística e contextualizada - por serem dotadas de um estilo especialmente aberto, já que se utilizam de questionamentos semiestruturados;

- Proporcionam ao entrevistador uma oportunidade de esclarecimentos, junto aos segmentos momentâneos de perguntas e respostas, possibilitando a inclusão de roteiros não previstos, sendo esse um marco de interação mais direta, personalizada, flexível e espontânea;

- Cumprem um papel estratégico na previsão de erros, por ser uma técnica flexível, dirigida e econômica que prevê, antecipadamente, os enfoques, as hipóteses e outras orientações úteis para as reais circunstâncias da investigação, de acordo com a demanda do entrevistado, propiciando tempo para a preparação de outros instrumentos técnicos necessários para a realização, a contento, da entrevista.

Para MANZINI (1990), a entrevista semiestruturada está focalizada em um assunto sobre o qual se confecciona um roteiro com perguntas principais, complementadas por outras questões inerentes às circunstâncias momentâneas à entrevista. Para 0 autor, esse tipo de entrevista pode fazer emergir informações de forma mais livre e as respostas não estão condicionadas a uma padronização de alternativas. 


\section{MATERIAL E MÉTODOS}

Seguem os procedimentos metodológicos utilizados na pesquisa em questão.

\subsection{Caracterização da pesquisa}

De acordo com KIRSCH e LEMES (2019), esta pesquisa caracteriza-se como: a) Pela natureza: como pesquisa aplicada, com o objetivo de gerar conhecimentos para aplicação prática na solução de problemas relacionados à gestão informatizada de propriedades rurais; b) Quanto aos objetivos: pesquisa exploratória e pesquisa ação, pois envolve o levantamento de demanda e conhecimento das questões que envolvem o acesso dos produtores à rede internacional de computadores, cujos resultados induziram correções de rumo no desenvolvimento do software Nav Agro Brasil; c) Quanto à abordagem do problema: pesquisa qualitativa e quantitativa, ao buscar reconhecer as necessidades do público alvo bem como das condições para uma possível digitalização da gestão; d) Quanto aos procedimentos técnicos: foram utilizados referencial bibliográfico e pesquisa com dados primários junto aos produtores respondentes via survey no Google Form; e) Como Instrumento e coleta de dados: a pesquisa utilizou-se de dados de mercado, dados primários e técnicas estatísticas; e, f) Para a análise de dados foi utilizada uma estatística descritiva e de análise multivariada, a fim de estruturar e analisar os dados referentes aos problemas investigados.

Portanto, utilizou-se uma pesquisa exploratória/ação qualitativa e quantitativa. Uma das bases de dados de dados utilizadas partiu de amostragem do Censo Agropecuário (IBGE, 2017). A amostra trouxe dados relevantes dos empreendimentos rurais dos últimos dez anos, como base a identificar o perfil, possíveis pontos de atenção e oportunidades de profissionalização.

No levantamento bibliográfico foi considerado obras relativas ao agronegócio, tecnologias da informação, ferramentas de gestão e controle. Assim, do ponto de vista do objetivo, a pesquisa teve características exploratória, que visa proporcionar maior familiaridade com o problema e com intuito de torná-lo explícito (GIL, 2009). 


\subsection{Dados qualitativos e aspectos éticos da pesquisa}

Para atingir os objetivos desta pesquisa, entre outras estratégias, foi criada uma planilha com as respostas da survey junto aos respondentes para caracterizar as 70 respostas obtidas, no período de 4 meses, cuja planilha foi utilizada como base da análise qualitativa e quantitativa para o estudo em questão.

Os respondentes tiveram acesso aos formulários online, divulgados pela coordenação do projeto de pesquisa, apoiando-se em comunicação clara e transparente dos objetivos a serem alcançados e com absoluta garantia de que os dados preenchidos, de forma voluntária, são de natureza sigilosa e a preservar os direitos daqueles que entenderem importante fazer seus depoimentos e entrevistas.

Para cada avaliador, foi solicitado evidência de aceitação do Termo de Consentimento Livre e Esclarecido (TCLE), que se encontra em sua estrutura original do questionário no APÊNDICE, para pesquisas online que estabeleceu diretrizes para: a) Riscos e Benefícios; b) Sigilo e Privacidade; c) Autonomia; d) Ressarcimento e Indenização; e) Contatos; f) Comitê de ética; g) Declaração e h) Uso de imagem. Por respeito à privacidade dos respondentes, o nome ou qualquer dado ou elemento que possa, de qualquer forma, identificá-lo foi mantido em sigilo.

\subsection{Contextualização do objeto de estudo}

A fim caracterizar o potencial de desenvolvimento de um software para a aplicação em empreendimentos rurais, a metodologia utilizada foi baseada em pesquisa qualitativa e quantitativa com arrendatários, produtores rurais e gestores de propriedades rurais, através de um questionário com respostas abertas e fechadas (APÊNDICE) aplicado online via Google formulários para potenciais usuários do software a ser proposto e entrevistas com especialistas e formadores de opinião na área de gestão. Esse instrumento de coleta de dados, constituído por uma série ordenada de perguntas, devem ser respondidas por escrito e sem a presença do entrevistador (MARCONI; LAKATOS, 2003). Além disso, é normalmente utilizado não só na pesquisa qualitativa, mas também para identificar os pontos relevantes a serem levantados e analisados nas entrevistas 
selecionadas. Tratou-se de uma conversação dirigida a um propósito definido que não é a satisfação da conversação em si, pois esta última é mantida pelo próprio prazer de estabelecer contato sem ter o objetivo final de trocar informações, ou seja, diminuir as incertezas acerca do que o interlocutor diz (HAGUETE, 2001; LODI, 1991).

Segundo YIN (2001), a escolha dos objetos de estudo deve obedecer a critérios de proximidade com o autor da pesquisa, caso contrário, corre-se o risco de inviabilizála financeiramente ou em termos de visibilidade.

$\mathrm{Na}$ aplicação de um questionário online, fomenta-se uma maior probabilidade de recusa por parte do respondente, por diversas variáveis, entre elas: fechamento da janela do navegador e assim, a descontinuidade no preenchimento e endereços de e-mail desatualizados ou incompletos. Desta forma, dependendo do tamanho da amostra que se pretende construir, é necessária uma listagem bastante extensa de contatos (ALONSO e MIRANDA, 2016).

Tabela 8 - Meios alternativos de comunicação e coleta de informações aos agentes entrevistados

\begin{tabular}{ccccc}
\hline $\begin{array}{c}\text { Meios de } \\
\text { comunicação }\end{array}$ & $\begin{array}{c}\text { Quantidade de } \\
\text { indivíduos }^{(1)}\end{array}$ & $\begin{array}{c}\text { Quantidade de } \\
\text { contatos } \\
\text { efetuados }^{(2)}\end{array}$ & $\begin{array}{c}\text { Quantidade de } \\
\text { respostas }\end{array}$ & $\begin{array}{c}\text { Taxa de } \\
\text { resposta positiva } \\
(4)\end{array}$ \\
\hline E-mail & 350 & 1.400 & 8 & $2,29 \%$ \\
Facebook & 4 & 5 & 2 & $50,00 \%$ \\
Whatsapp & 48 & 55 & 25 & $52,08 \%$ \\
Contato pessoal & 35 & 45 & 35 & $100,00 \%$ \\
\hline
\end{tabular}

(1) Quantidade de indivíduos: número de respondentes contatado.

Quantidade de contatos efetuados: volume de vezes que um mesmo individuo foi contatado.

Quantidade de respostas: quantas respostas positivas obteve da quantidade de indivíduos contatado.

(4) Taxa de resposta positiva: percentual (\%) obtido entre a variável volume de respostas versus quantidade de indivíduos.

Fonte: Elaborado pelo autor.

Ressalvadas as devidas considerações, foi utilizado algumas estratégias na aplicação e coleta das informações do questionário online, visando minimizar o efeito negativo da baixa taxa de resposta. Para isso, procurou-se quadro meios de comunicação como formas alternativas de contato com os respondentes: e-mail; facebook; whatsapp; e contato pessoal (Tabela 8). 
O meio de comunicação pessoal ocorreu através de entrevistas presenciais junto aos produtores rurais ou gestores de propriedades rurais, em meio ao agendamento realizado, por telefone, sem o respectivo cancelamento ou rejeição por parte dos entrevistados - os quais aceitaram prontamente o convite. Esta alternativa sinalizou melhor taxa de retorno com $100 \%$ de representatividade frente aos indivíduos e possibilitou um aprendizado construtivo junto ao entrevistador - o qual teve a possibilidade de vivenciar a realidade dentro do estabelecimento rural.

Os meios de comunicação por whatsapp e facebook também se comportaram como estratégias positivas na obtenção das respostas. Dos 52 indivíduos contatados, alguns se mostraram resistentes ou inseguros em colaborar com a pesquisa. $O$ fator que determinou uma melhor eficiência nas respostas foi o texto redigido de forma simples, clara e objetiva, sem exaurir o entrevistado e com informação do indicante. Outro aspecto observado foi a confiança do respondente em saber que seu contato foi indicado, e a menção do indicante no texto, foi determinante na obtenção da resposta, uma vez que a maioria dos contatos não faziam parte do networking do entrevistador. No geral, o tempo de resposta foi em média de 1 a 7 dias.

Por final, a principal dificuldade foi obter contatos de e-mail de produtores rurais ou gestores de propriedades rurais para conduzir a pesquisa. Assim, realizou-se uma pesquisa pela internet dos principais sindicatos rurais, por região, como forma de acesso ou divulgação da pesquisa junto aos produtores rurais. Dos 350 sindicatos contatos, apenas 1 retornou e cogitou a possibilidade de divulgar a pesquisa junto aos sindicalizados. Alguns dos e-mails constatados na base de dados dos sindicatos rurais eram de produtores rurais - representantes de sindicatos que colaboraram prontamente com a pesquisa. Muito embora o texto utilizado contenha informações acerca da pesquisa, inclusive com o termo de confidencialidade, a taxa de retorno foi baixa. Nesta modalidade o tempo médio de resposta foi entre 1 a 3 meses, dos respondentes.

\subsection{Análise dos dados da pesquisa}

Os dados coletados do questionário fechado foram tabulados e analisados por meio de técnica de análise estatística multivariada. 
Visando buscar relação de dependência entre variáveis categóricas que possam ajudar a identificar se existe potencial do uso de ferramentas remotas de gestão para controle e auxílio às tomadas de decisão na área financeira/contábil em empreendimentos rurais, vis-à-vis o acesso à rede de computadores, optou-se pelo uso da Análise de Correspondência Simples no estudo da relação entre cinco conjuntos de variáveis: recursos tecnológicos e tipos de controles, recursos tecnológicos e nível de escolaridade, tipos de controles e nível de escolaridade, índices de gestão e tipos de controles e, finalmente, conexões e velocidades de download.

Para a aplicação da técnica de Análise de Correspondência utilizou-se o software estatístico Minitab Inc Versão 18.

Paralelamente à análise estatística dos dados que compõem essa pesquisa, foram aproveitados depoimentos realizados por atores que possuem atividade dentro do universo de empresas rurais com potencial de uso do software, de forma a complementar as informações qualitativas e quantitativas trabalhadas.

\subsection{Oportunização do software Nav Agro Brasil}

Levando em consideração a possibilidade de uma demanda por uso de ferramenta remota de gestão para organização e controle das informações financeiras/contábeis, procurou-se a construção de uma opção de ferramenta que pudesse, futuramente, auxiliar o produtor, arrendatário ou gestor de propriedade rural no registro, organização e geração de informações financeiras, com vistas substituir possíveis uso de controles manuais (papel ou caderneta de anotações), bem como, fichas eletrônicas, contribuindo ao usuário, independentemente do nível de escolaridade, o armazenamento e geração de informações sem complicações e assim, auxiliar o processo decisório a qualquer momento e local, desde que tenha acesso à rede de computadores.

O referido software denominado Nav Agro Brasil, foi registrado no instituto nacional de propriedade industrial (INPI) sob o número de processo BR5120200019170, expedido em: 22/09/2020, cujo documento encontra-se no Anexo 1, bem como, sua apresentação estrutural no Apêndice 2 desta dissertação. 


\section{RESULTADOS E DISCUSSÃO}

Foram realizados pré-testes no questionário, uma vez que foi submetido à avaliação de três especialistas e à resposta de dezenas de pesquisas antes de seu amadurecimento final, contribuindo positivamente para isso as opiniões de melhorias da composição final junto à sindicatos, cooperativas e produtores rurais, os quais foram diferenciais para que não houvessem dificuldades pelos respondentes. Muito embora, o objetivo inicial seria uma amostra maior, buscou por conveniência, utilizar as informações dos empreendimentos rurais respondentes distribuídos pelas regiões (Figura 8).

Figura 8 - Número de respondentes por região.

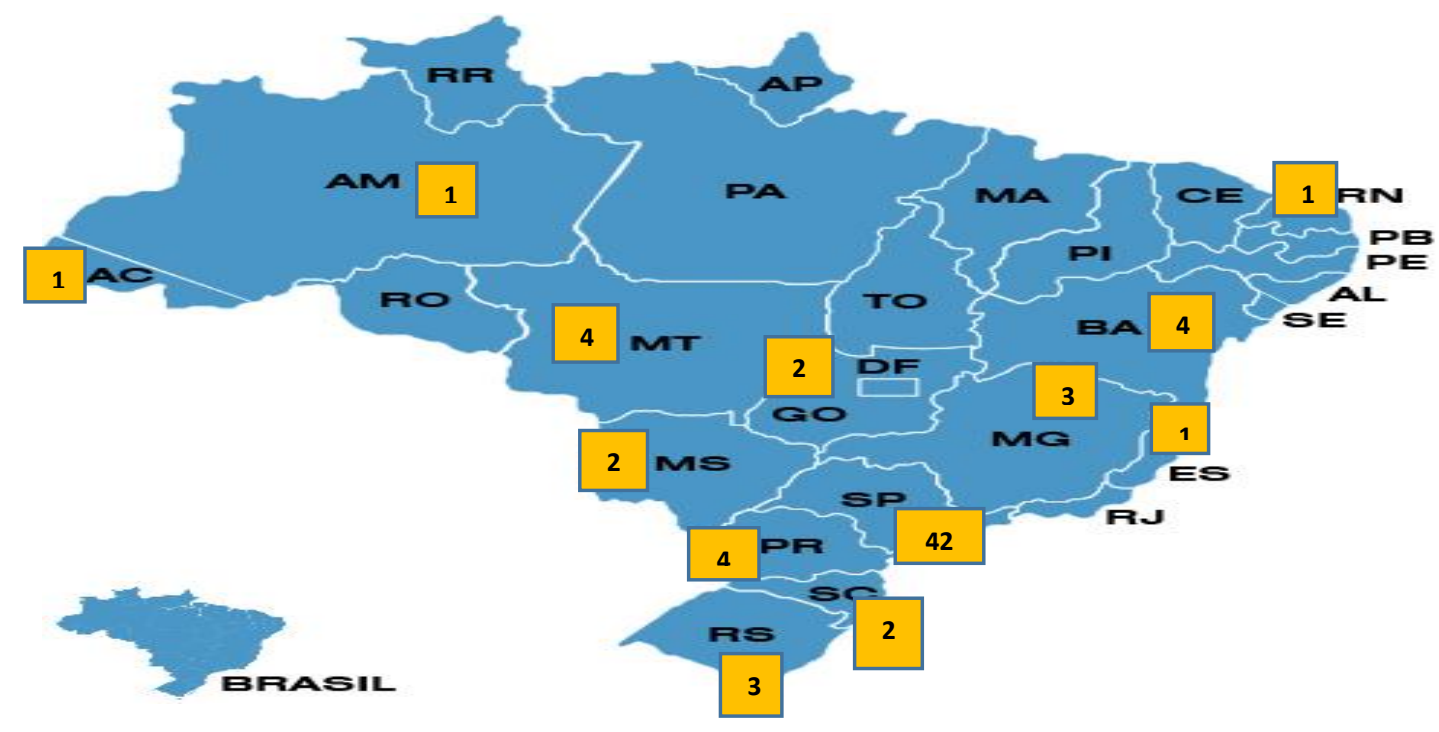

Fonte: Elaborado pelo autor.

O foco da pesquisa foi levantar o potencial de empreendimentos rurais que demandem por um processo de gestão com o uso de ferramenta digital, levando-se em consideração aspectos de localização, segmentação, tipos de culturas, tipos de controles produtivos, formas de gestão, nível de escolaridade, composição empresária, endividamento, entre outras. 
Além disso, a pesquisa também buscou retratar a realidade no uso dos recursos da tecnologia da informação - hardware (parte física): computadores, smartphones, tablets e celulares; e software (parte lógica): programas de computador, aplicativos mobile, sistemas de informações, bem como, sua conexão à rede de computadores no Brasil, de modo a identificar futuros consumidores para o modelo de ferramenta tecnológica para auxílio na gestão financeira dos empreendimentos rurais no Brasil denominado Nav Agro Brasil. A seguir, o diagnóstico apontando para uma demanda positiva por uso de ferramentas eletrônicas.

\subsection{Linhas de financiamentos adquiridos pelos empreendimentos rurais}

Dos respondentes, $60 \%$ relataram que possuem linhas de crédito, sendo mais comum a linha conhecida como PRONAF. De acordo com o BNDES (2019) esta modalidade tem por finalidade financiar o custeio e investimentos em implantação, ampliação e modernização da estrutura de produção, beneficiamento, industrialização e de serviços no estabelecimento rural ou em áreas comunitárias rurais próximas, visando a geração de renda e à melhoria do uso da mão de obra familiar.

Das 42 propriedades rurais, $50 \%$ adquiriram esta modalidade de financiamento. Segundo o Banco do Brasil (2019), cada produtor pode financiar até $R \$ 250$ mil por ano agrícola, com algumas particularidades nas taxas de juros, que podem variar entre 3,0\% a.a. e $4,6 \%$ a.a. e período para amortização decorrentes da cultura praticada na propriedade, que podem variar entre 1 a 3 anos com foco na agricultura familiar. As demais propriedades adquiriram outras linhas de financiamento rural: PRONAF, Pronamp, Cédula de Crédito Rural, Crédito Pessoal, FEAP Investimentos, Finame, FCO/CPR entre outras (Figura 9). 
Figura 9 - Linhas de financiamento rural adquirido pelos estabelecimentos rurais

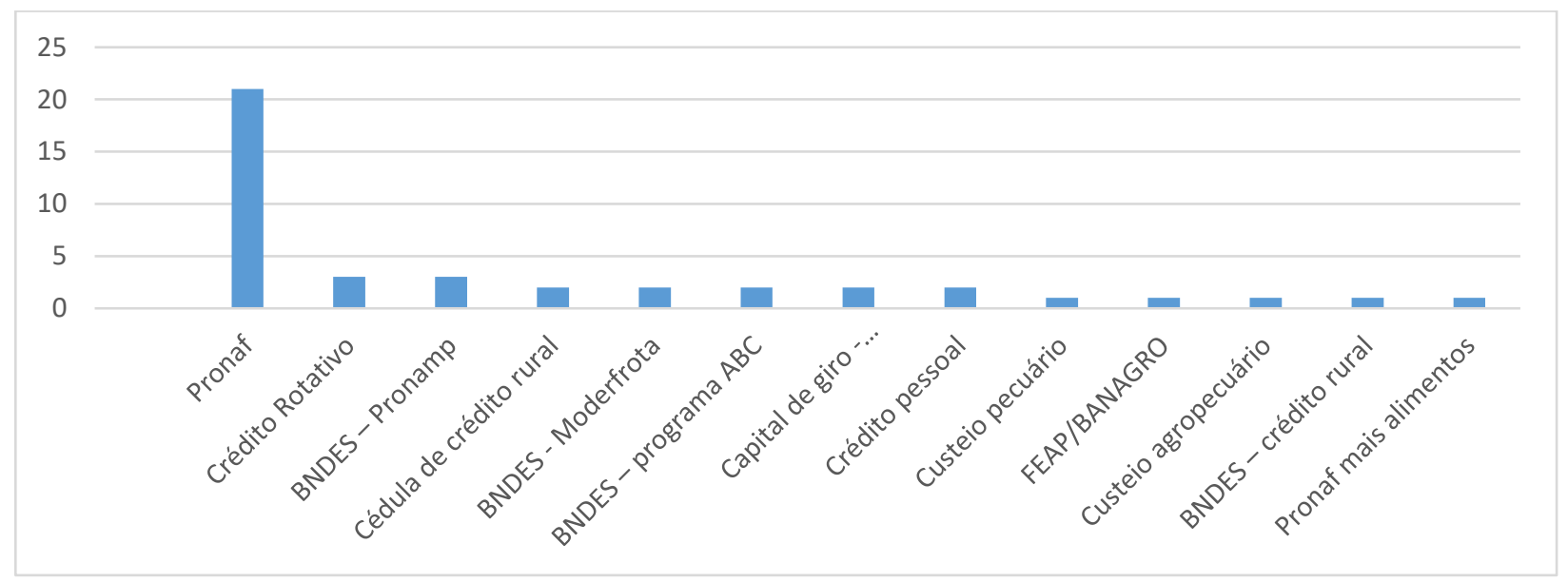

Fonte: Elaborado pelo autor.

Embora a amostra não represente a realidade do País, mas apenas de uma parcela contributiva da pesquisa, a predominância pela linha PRONAF vem ao encontro da pesquisa apontada pelo Censo Agropecuário IBGE (2017), o qual ressalta que 320.922 estabelecimentos agropecuários possuem a linha de financiamento denominada PRONAF como forma de alavancagem das suas operacionalidades.

\subsection{Ramo(s) de atividade(s), produto(s) ou serviço(s) comercializado(s) pelo empreendimento rural e suas respectivas localidades}

O estudo apontou que $58 \%$ dos estabelecimentos rurais possuem uma única atividade, assim compreendida, como a prática de uma única cultura, seja pecuária ou agrícola. Deste contingente, se destacam as propriedades com localização nos Estados: AC, AM, MG, MT, RS, RN e SP. Os demais Estados possuem diversificação na atividade rural, ou seja, a prática comercial entre duas culturas diferentes ou produtos e serviços diferentes dentro de uma mesma cultura, representando, assim $43 \%$ da amostra, com destaque para os Estados: ES e PR (Figura 10). 
Figura 10 - Percentual de estabelecimentos rurais com atividades: única e diversificadas (1).

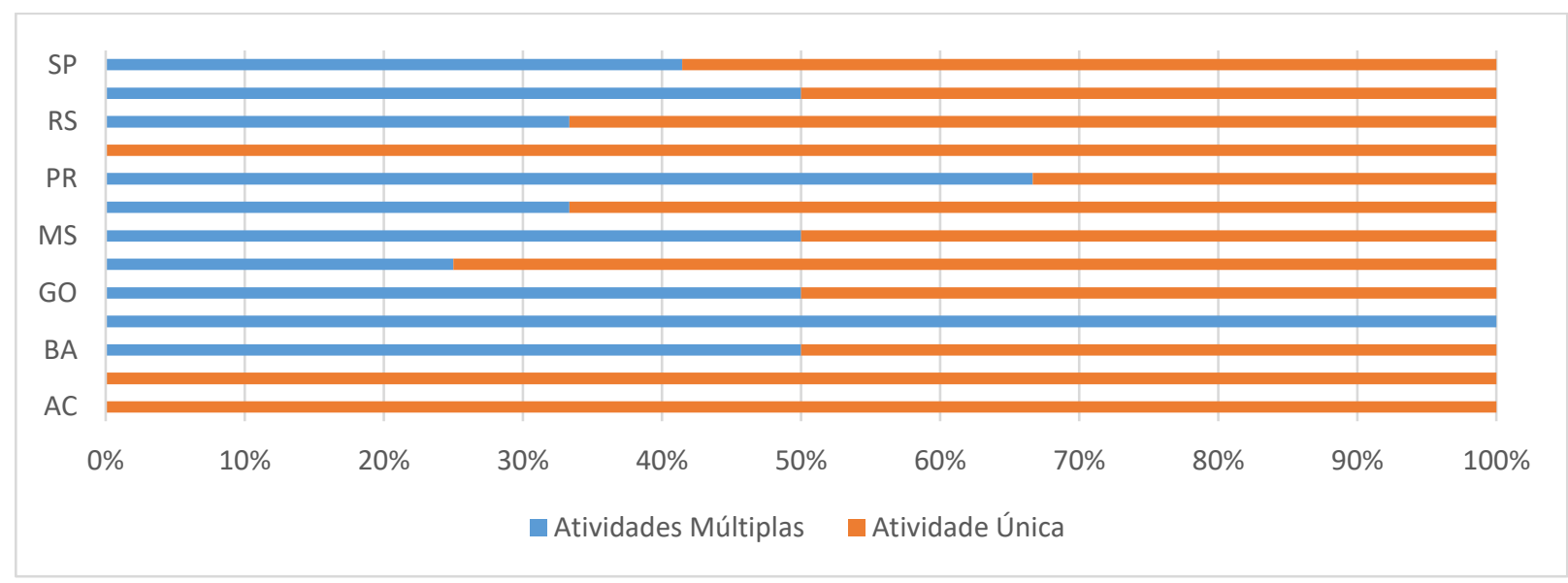

(1) Permitem respostas múltiplas

Fonte: Elaborado pelo autor.

Quando analisa-se a representatividade das atividades, produtos ou serviços comercializados por tipo de cultura, levando em consideração a quantidade de atividades por propriedade rural entre agrícola e pecuária, verifica-se que há maior preponderância para a prática da agricultura, assim compreendida pela extração, vegetal, floricultura, horticultura, cultura permanente, cultura temporária e silvicultura, com representatividade de $56 \%$ da amostra.

Os estabelecimentos rurais com localização nos Estados: AM, BA, ES, PR, SC e SP apontaram maior prática na comercialização agrícola, os demais Estados: AC, GO, MG, MS, MT e RN na Pecuária: bovinos, aves, abelhas, equinos, muares e ovinos (Figura 11). 
Figura 11 - Percentual de atividades, produtos ou serviços comercializados por Estado

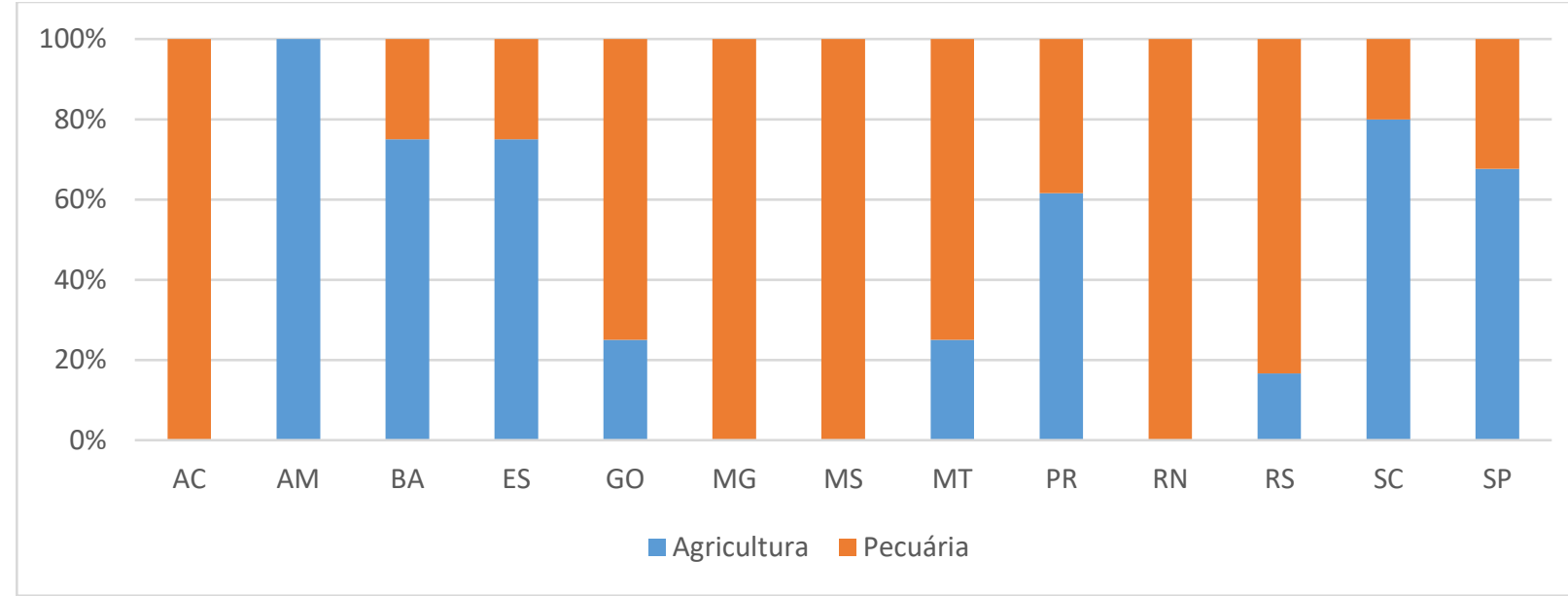

(1) Permitem respostas múltiplas

Fonte: Elaborado pelo autor.

Esta relação de representatividade entre as atividades agrícola e pecuária, quando comparadas ao PIB Agropecuário Brasileiro - que é uma metodologia desenvolvida pelo Centro de Estudos Avançados em Economia Aplicada (ESALQ/USP), verifica-se que o segmento agrícola (setor vegetal) se destaca de forma significativa com $72,92 \%$ do PIB Agropecuário, resultando o segmento pecuário (setor animal) com 27,08\% do montante movimentado em 2018. Essa representatividade, numa escala percentual um pouco menor também foi observada na presente pesquisa junto as atividades comerciais praticadas pelos estabelecimentos rurais.

$\mathrm{Na}$ atividade agrícola, a cultura temporária representa $51 \%$ das atividades comercializadas nos estabelecimentos rurais quando comparada com as demais atividades agrícolas. A cana de açúcar se destaca como a principal, seguido pelo milho e soja nos Estados: BA, MT, PR, SC e SP. A silvicultura tem destaque nos Estados de AM e MS, a horticultura no Estado de SP e as culturas permanente nos Estados de MG, ES e RS. Os estabelecimentos agropecuários não apresentação comercialização de produtos agrícolas nos Estados de GO e RN (Figura 12). 
Figura 12 - Percentual de atividades comercializadas por Estado na agricultura

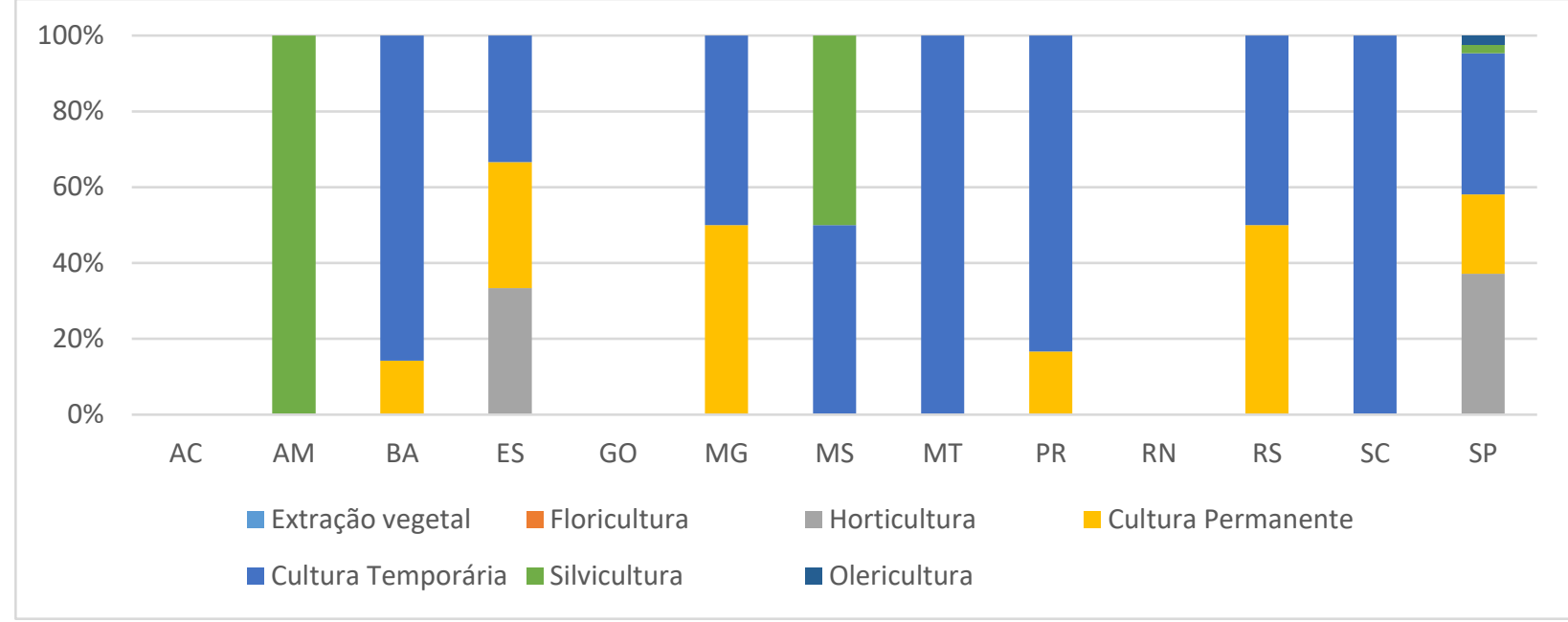

(1) Permitem respostas múltiplas

Fonte: Elaborado pelo autor.

A pesquisa apontou que o Estado de São Paulo possui forte concentração nas atividades de comercialização de cana de açúcar, evidenciando a mesma constatação apontado no Censo Agropecuário IBGE (2017), onde o Estado produziu 54\% do volume Nacional de cana de açúcar, seguido pelos Estados de Goiás, Minas Gerais, Mato Grosso do Sul e Paraná.

Dos estabelecimentos rurais que atuam na atividade pecuária (Figura 13), 82\% praticam comercialização de bovinos, assim compreendidos na pesquisa: pecuária de corte e leite, com destaque na maioria dos Estados, em especial as regiões de: GO, MG, MS, MT, PR e SP. A região de RN se destaca na comercialização de muares. 
Figura 13 - Percentual de atividades comercializadas por Estado na pecuária

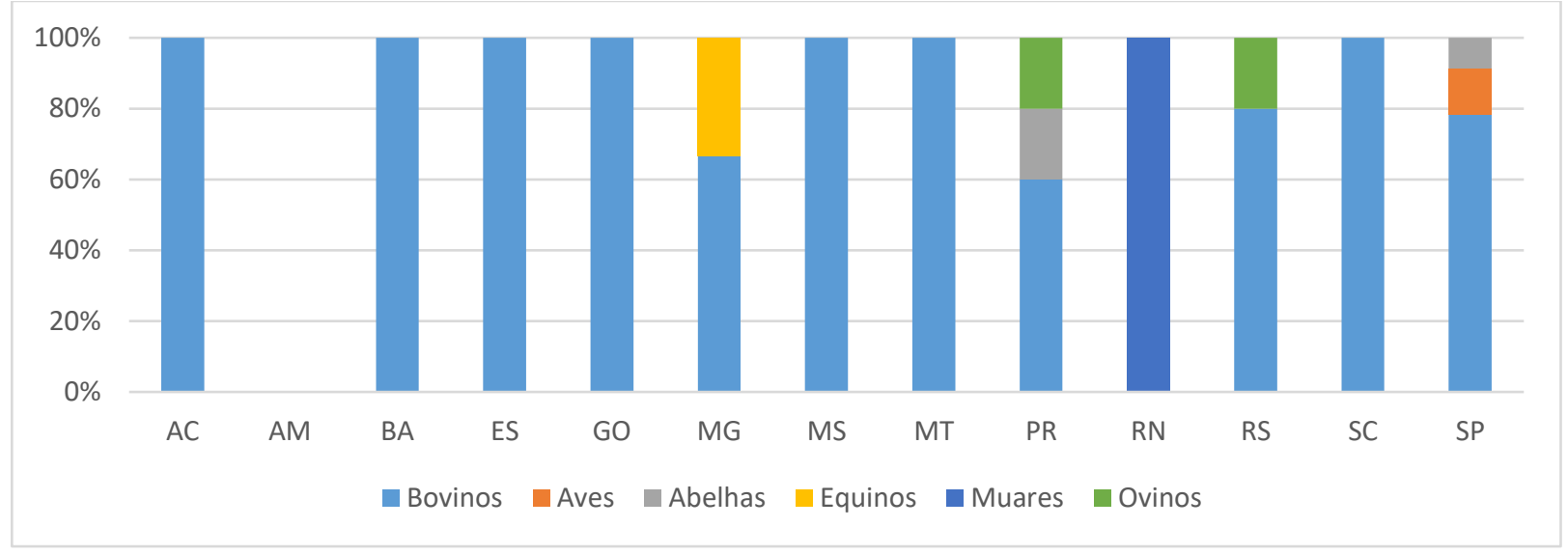

(1) Permitem respostas múltiplas

Fonte: Elaborado pelo autor.

Segundo Censo Agropecuário IBGE (2017), nota-se que, quando observadas em valores agregados de cabeças o rebando de bovinos tem forte concentração nos Estados: MT, MG, MS, GO e PR, representando 55\% do efetivo de 172.719 .164 cabeças, é o mesmo comportamento observado na pesquisa quando comparado a variável percentual de atividades comercializadas, salvo exceção no Estado de SP que na pesquisa apresentou mais preponderância a esta atividade. Também, quando comparado em termos de concentração por espécie, o Censo Agropecuário IBGE (2017) e a pesquisa apresentada, salvo exceção às aves, verifica-se que a região Centro-Oeste e Sudeste se destacam na concentração de bovinos e a região Nordeste se destaca no número de cabeças de asininos, muares, caprinos e ovinos.

\subsection{Perfil dos gestores e composição empresária dos empreendimentos rurais}

O objetivo principal destes quesitos foi identificar se o respondente se posiciona como arrendatário, proprietário, gestor ou outra forma de atuação na condução das atividades na propriedade. Além disso, identificar o modelo de composição societária, se de forma capitalista, familiar ou arrendamento, quem faz a gestão da propriedade, sua faixa etária e nível de escolaridade. Dos dados apurados, 14\% das propriedades estão 
estruturadas em composição empresária na forma de arrendamento, $7 \%$ se identificam como sistema capitalista, $1 \%$ não se identificou com as alternativas e a maioria dos respondentes, cerca de $78 \%$ como familiar (Figura 14).

Figura 14 - Resumo da composição empresária nas propriedades rurais

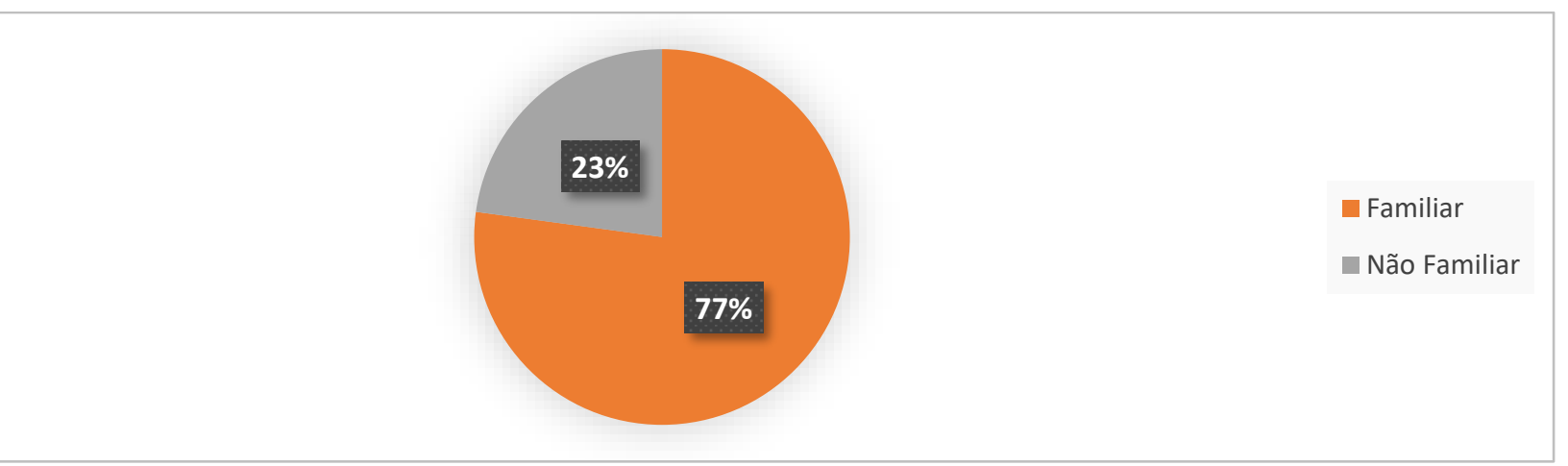

Fonte: Elaborado pelo autor.

Embora a amostra não represente a realidade do País, vem ao encontro com o levantamento do Censo Agropecuário do IBGE (2017), que constatou uma preponderância pelo modelo de composição empresária familiar na ordem de 77,0\%, perfazendo 3,9 milhões de estabelecimentos rurais.

A pesquisa também apontou que uma parcela das propriedades, são geridas por produtores, arrendatários ou gestores profissionais com nível de educação elementar, fundamental ou médio, superior, quando comparado aos de nível superior (Figura 15). 
Figura 15 - Quantidade de estabelecimentos rurais por nível de escolaridade de quem faz a gestão.

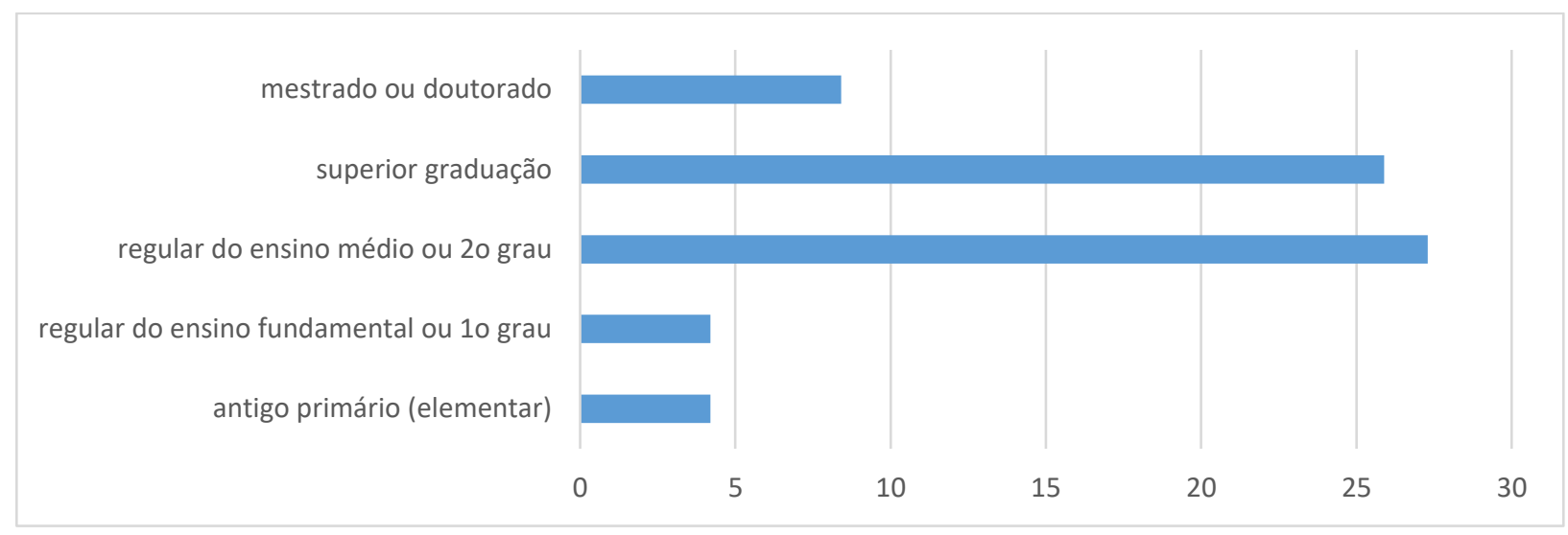

Fonte: Elaborado pelo autor.

Não obstante, quando analisado o nível de educação por tipo de gestão, verificase uma concentração maior de proprietários com baixo nível de escolaridade quando comparado com gestor profissional, onde há maior concentração de nível de escolaridade (Figura 16).

Figura 16 - Níveis de escolaridade de quem faz a gestão na propriedade.

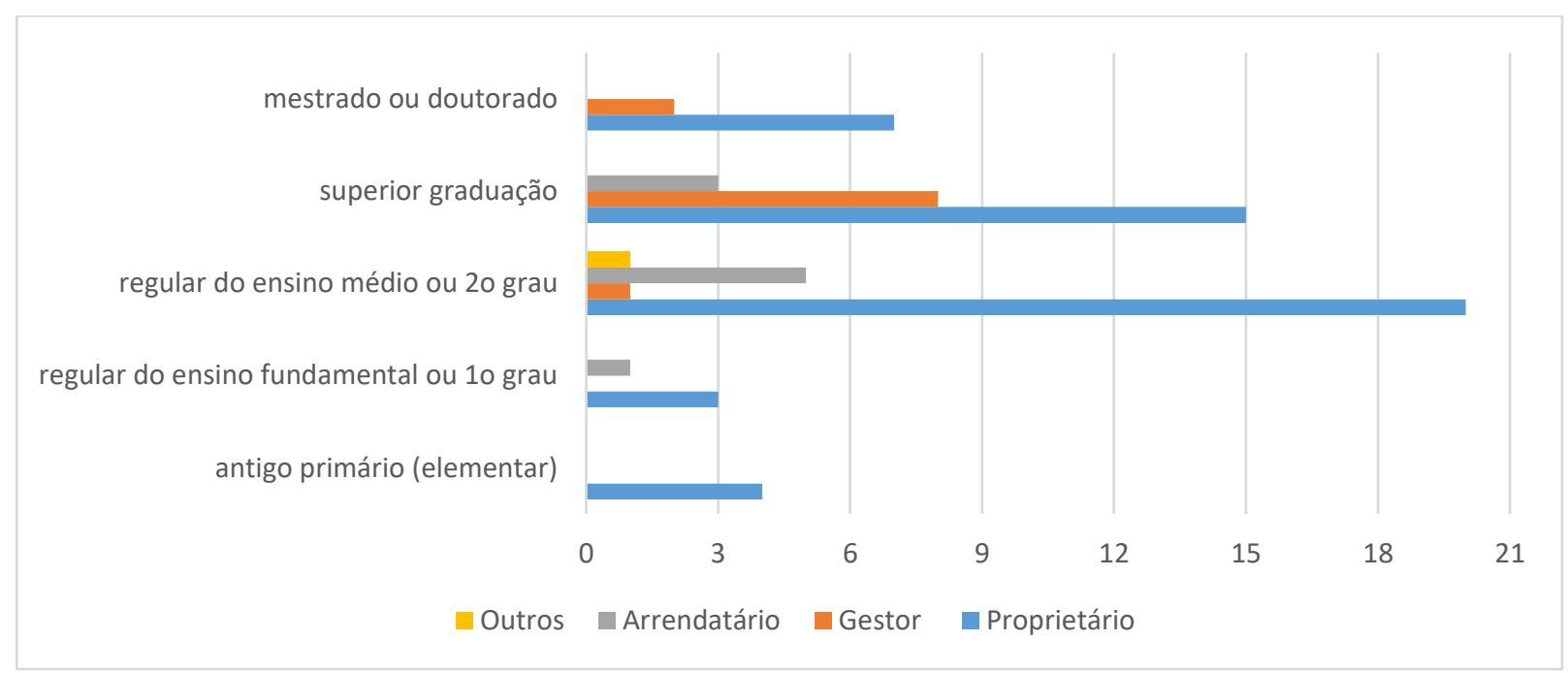

Fonte: Elaborado pelo autor. 
Mesmo havendo uma considerável parcela de gestores com nível de graduação, mestrado ou doutorado, ainda há preponderância para os de menor nível de escolaridade como constata o Censo Agropecuário do IBGE (2017), onde 24\% possuem o antigo primário (elementar), 19\% regular do ensino fundamental ou $1^{\circ}$ grau e $13 \%$ regular do ensino médio ou $2^{\circ}$ grau. Nesta vertente, SEBRAE (2018) aponta que $70 \%$ dos produtores rurais apresentam baixo nível de escolaridade, com um singelo aumento de 5 pontos percentuais entre os trimestres de 2015 e o primeiro de 2018 (de $75 \%$ para $70 \%$ ).

Segundo Breitenbach (2014), o Brasil tem se destacado como um importante produtor e exportador de derivados do Agronegócio, mas ainda há baixa escolaridade dos agricultores, o seu despreparo para a gestão rural, de custos entre outras. Para Callado e Callado (2002), o baixo nível de escolaridade nas propriedades rurais impede a utilização de métodos mais sofisticados no processo de tomada de decisão, provocando, por exemplo, a falta de precisão nos custos que poderá comprometer a qualidade das decisões tomadas.

Por final, o estudo apontou que $50 \%$ de quem faz a gestão nas propriedades é o proprietário, que possui idade entre 45 a 64 anos e numa escala menor até 24 anos. A faixa etária do gestor profissional se comporta entre 35 a 44 anos, o arrendatário entre 25 a 34 anos e 55 a 64 anos (Figura 17). Essa tendência também é observada no Censo Agropecuário IBGE (2017) onde há uma forte concentração na faixa etária entre 45 e 74 anos, e numa escala menor abaixo de 24 anos. 
Figura 17 - Faixa etária de quem faz a gestão nas propriedades.

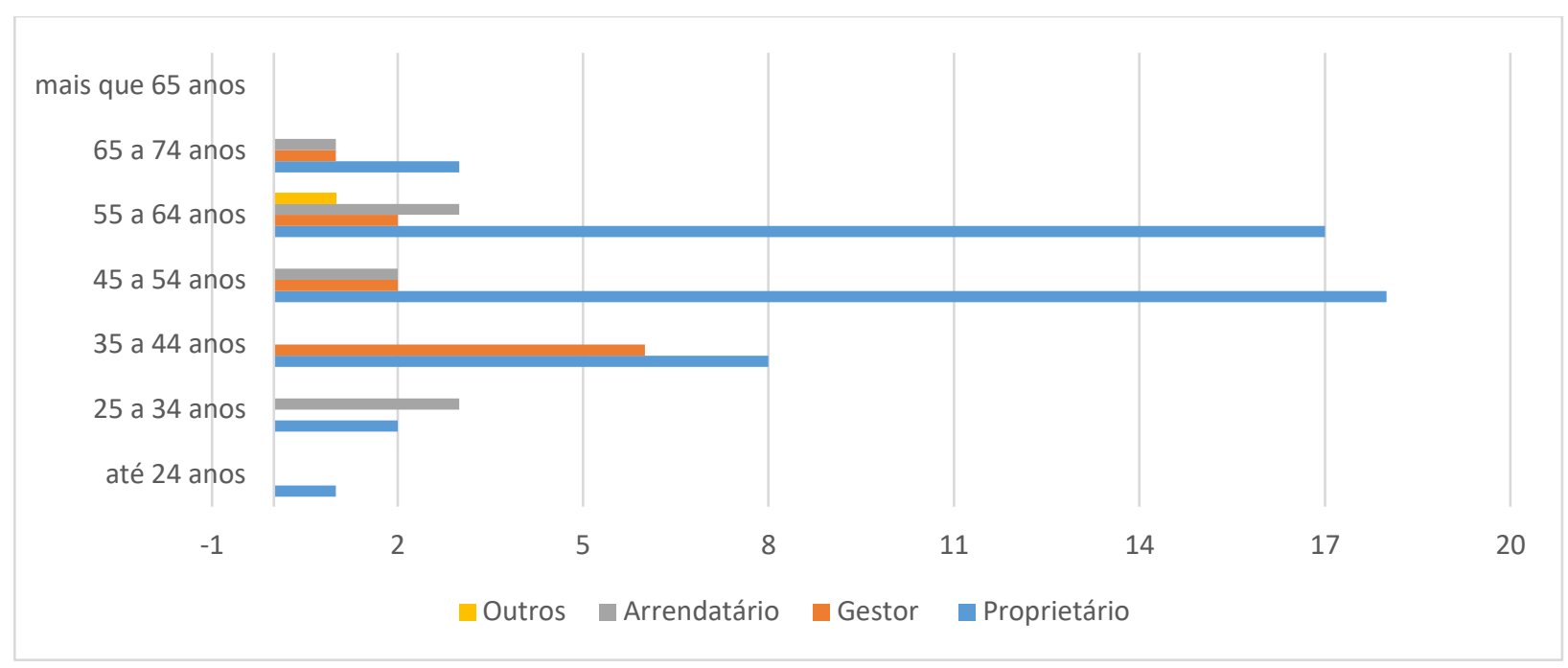

Fonte: Elaborado pelo autor.

\subsection{Tamanho (em hectares) dos empreendimentos rurais e a estrutura} operacional de funcionários ou membros familiares empregados nas atividades comerciais

Segundo o INCRA (2020), o conhecimento da estrutura fundiária de cada nação é imprescindível para auxiliar na análise e tomada de decisões a respeito de atividades que contribuam para o desenvolvimento rural e de apoio à agricultura familiar e empresarial, entre outras. Neste sentido, a pesquisa apontou que $43 \%$ dos empreendimentos rurais possuem mais de 50 hectares, 24\% possuem menos que 5 hectares, $17 \%$ de 21 a 50 hectares e $16 \%$ de 6 a 20 hectares (Figura 18). 
Figura 18 - Empreendimentos rurais por tamanho em hectares

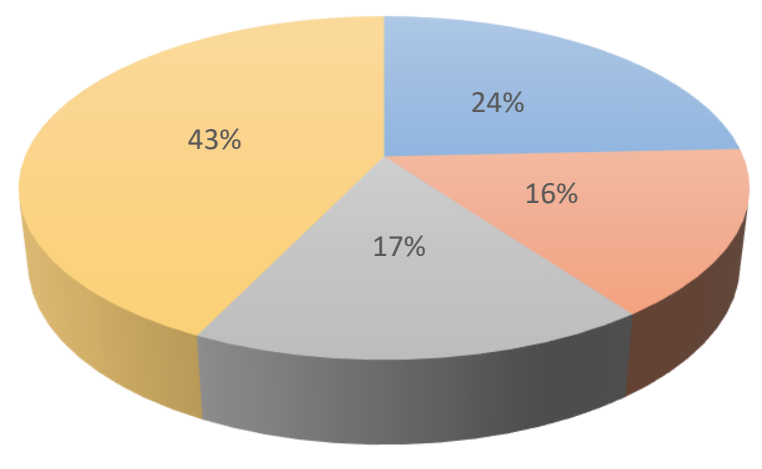

Fonte: Elaborado pelo autor.

A pesquisa também apontou que, independentemente do tamanho do empreendimento rural, 74\% empregam menos do que 5 funcionários em suas atividades comerciais ou produtivas e com uma preponderância maior para os empreendimentos com mais de 50 hectares, o qual concentra 16\% com mais de 5 funcionários (Figura 19).

Figura 19 - Quantidade de funcionários ou membros familiares por tamanho de propriedade

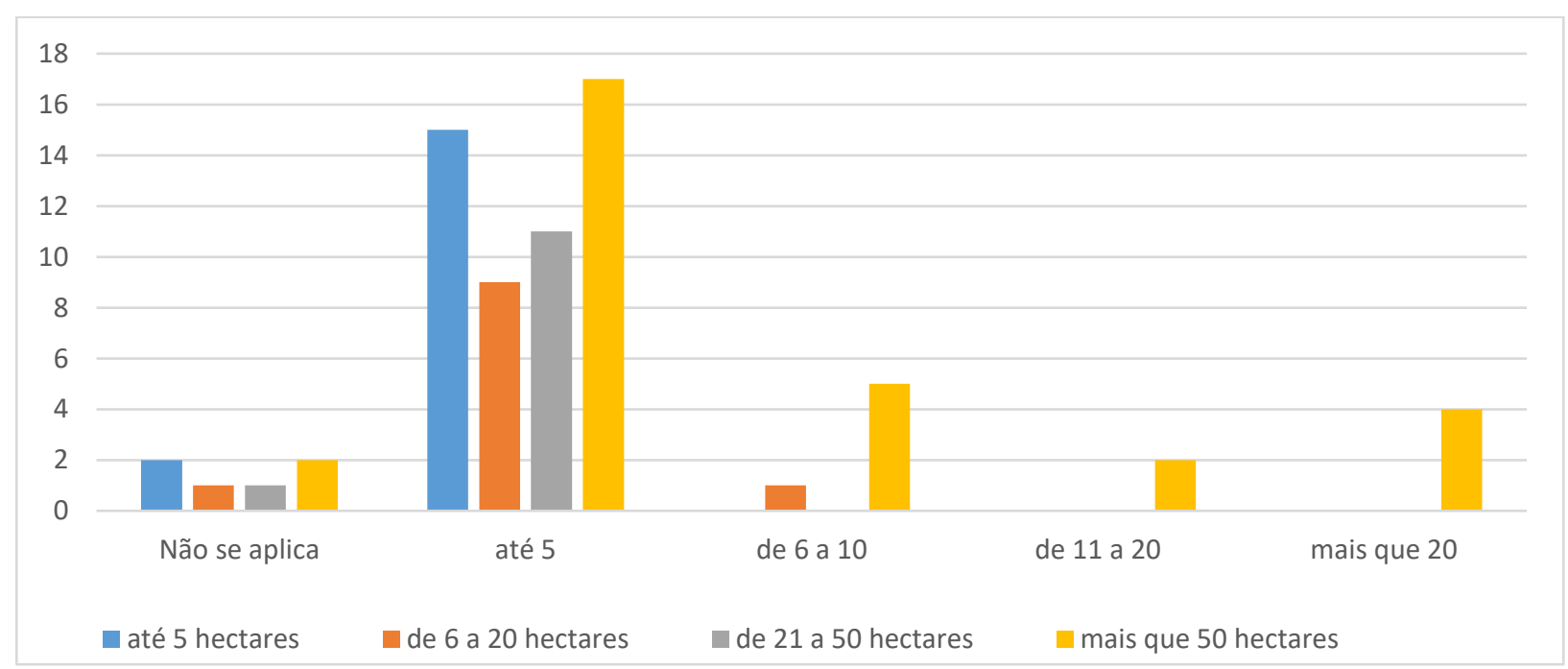

Fonte: Elaborado pelo autor. 


\subsection{Controles de custos produtivos nos empreendimentos rurais e suas prerrogativas quanto à existência, gestão, tipos, nível de escolaridade dos usuários e cultura agropecuária}

Independentemente do tipo de controle de custos e sua finalidade, diversos autores (citados na pesquisa acima) apontam a necessidade e profissionalização do segmento rural por meio de práticas de gestão empresária atrelado uso de técnicas ou controles como apoio ao processo decisório. Essas denominações foram classificadas em 3 categorias: manejo animal, cultivo vegetal e financeiro (Figura 20).

A pesquisa sinalizou, ainda, que $69 \%$ dos empreendimentos rurais possuem algum tipo de controle de custos como forma de gerir suas atividades, com maior representatividade nas propriedades com mais de 50 hectares (Figuras 21 e 22).

Por outro lado, $31 \%$ dos empreendimentos rurais não possuem controles de custos, com maior concentração em propriedades com menos de 50 hectares, o que corresponde a $82 \%$ desta variável (Figura 21).

Figura 20 - Percentual da atividade comerciais com controles de custos produtivos em empreendimentos rurais por definição de quem faz a gestão.

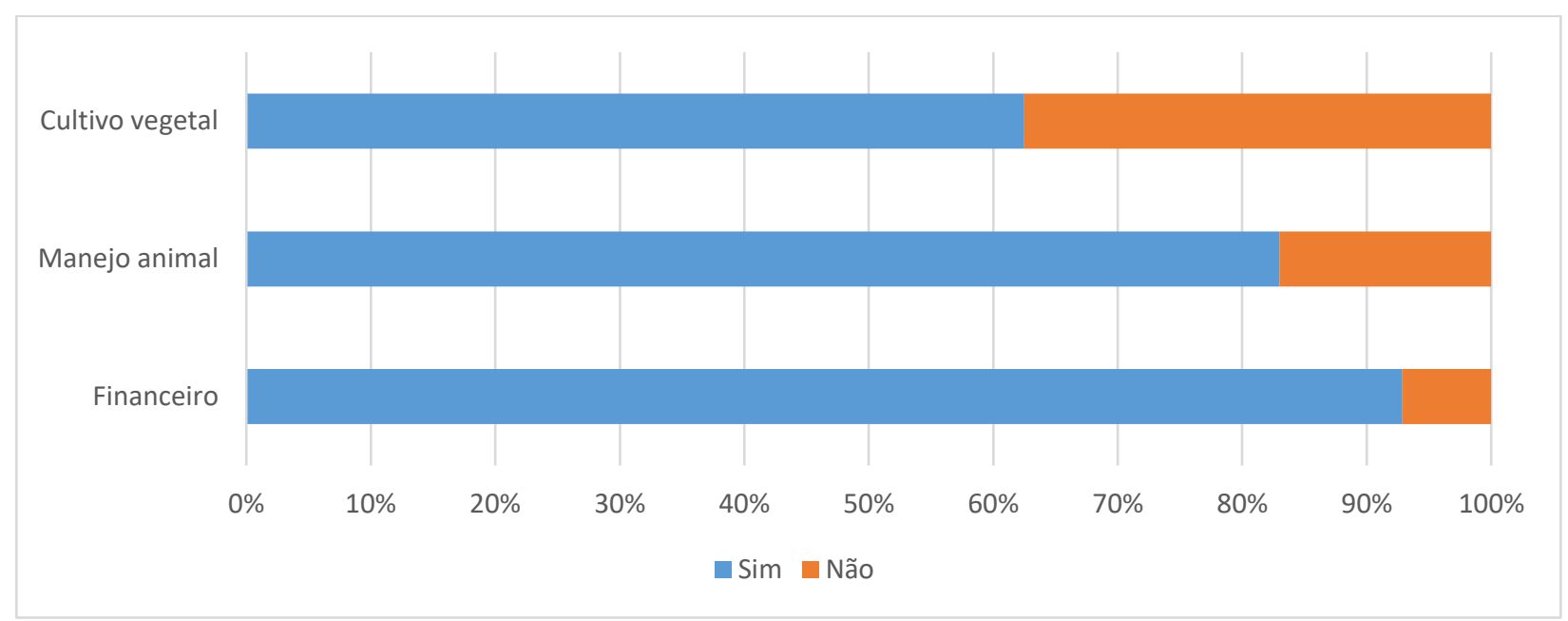

(1) Podem ter múltiplas respostas

Fonte: Elaborado pelo autor. 
Figura 21 - Percentual de existência de controles de custos produtivos nos empreendimentos rurais.

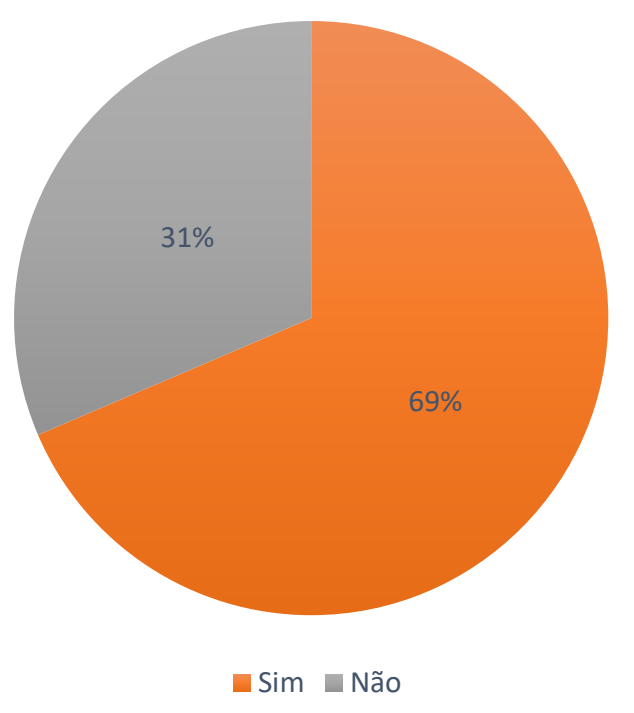

Fonte: Elaborado pelo autor.

Figura 22 - Percentual de controles de custos produtivos nos empreendimentos rurais por tamanho em hectares.

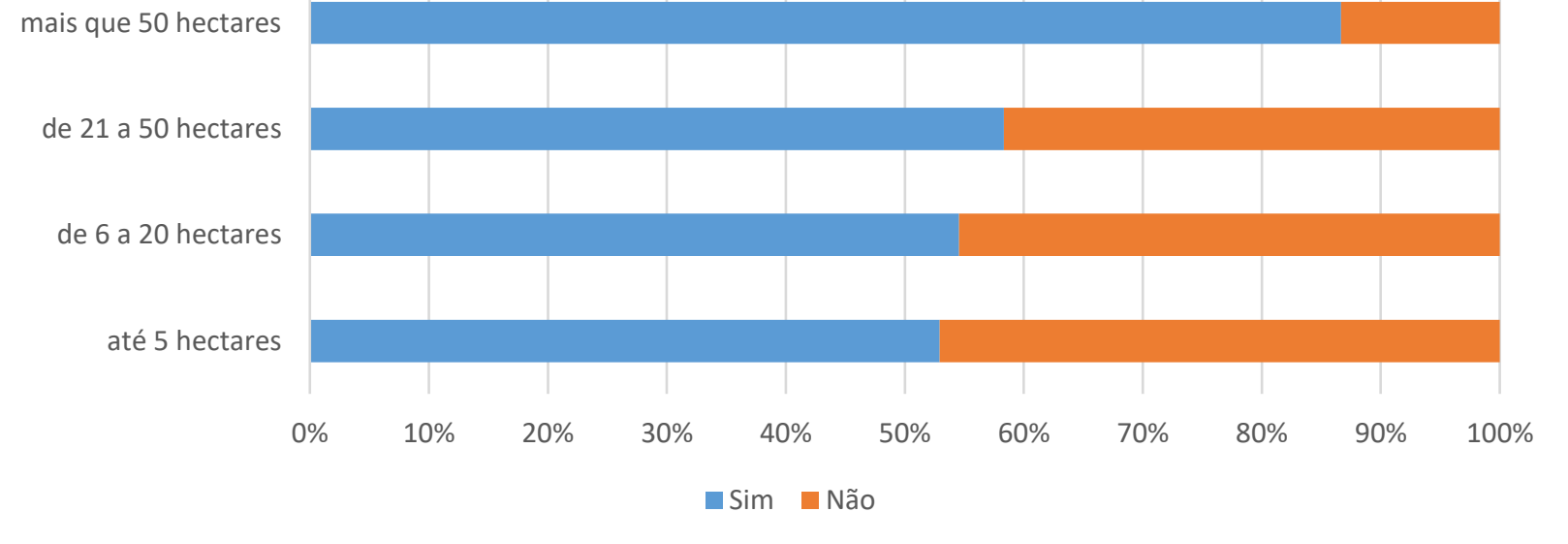

Fonte: Elaborado pelo autor.

Os tipos de controles de custos apontados são inerentes à cultura praticada e ao nível de escolaridade de quem faz a gestão, mas tidos como essenciais para gerir a propriedade. Entre eles, se destacam: compra de insumos produtivos; entrada, saída e 
estoque de animais; custo operacional fixo e variável; volume de produção (cultura vegetal); custos com IATF (veterinário, protocolo, sêmen, nitrogênio...), entre outros. Diversas foram as denominações apontadas pelos gestores quanto ao tipo de custo produtivo e finalidade.

Verificou-se também que o nível de escolaridade de quem faz a gestão nos empreendimentos rurais contribui para a ausência de práticas em controles de custos produtivos. Gestores com níveis de escolaridade superior: graduação, mestrado ou doutorado apresentaram maior preponderância ao uso de controles de custos representando $63 \%$ do que usam. Gestores com níveis de escolaridade antigo primário (elementar), regular do ensino fundamental $1^{\circ}$ grau e regular do ensino médio ou $2^{\circ} \mathrm{grau}$, apresentaram menos predisposição ao uso de controles de custos com representatividade de $73 \%$ dos que não usam (Figura 23 ).

Figura 23 - Percentual de controles de custos produtivos nos empreendimentos rurais por nível de escolaridade de quem faz a gestão.

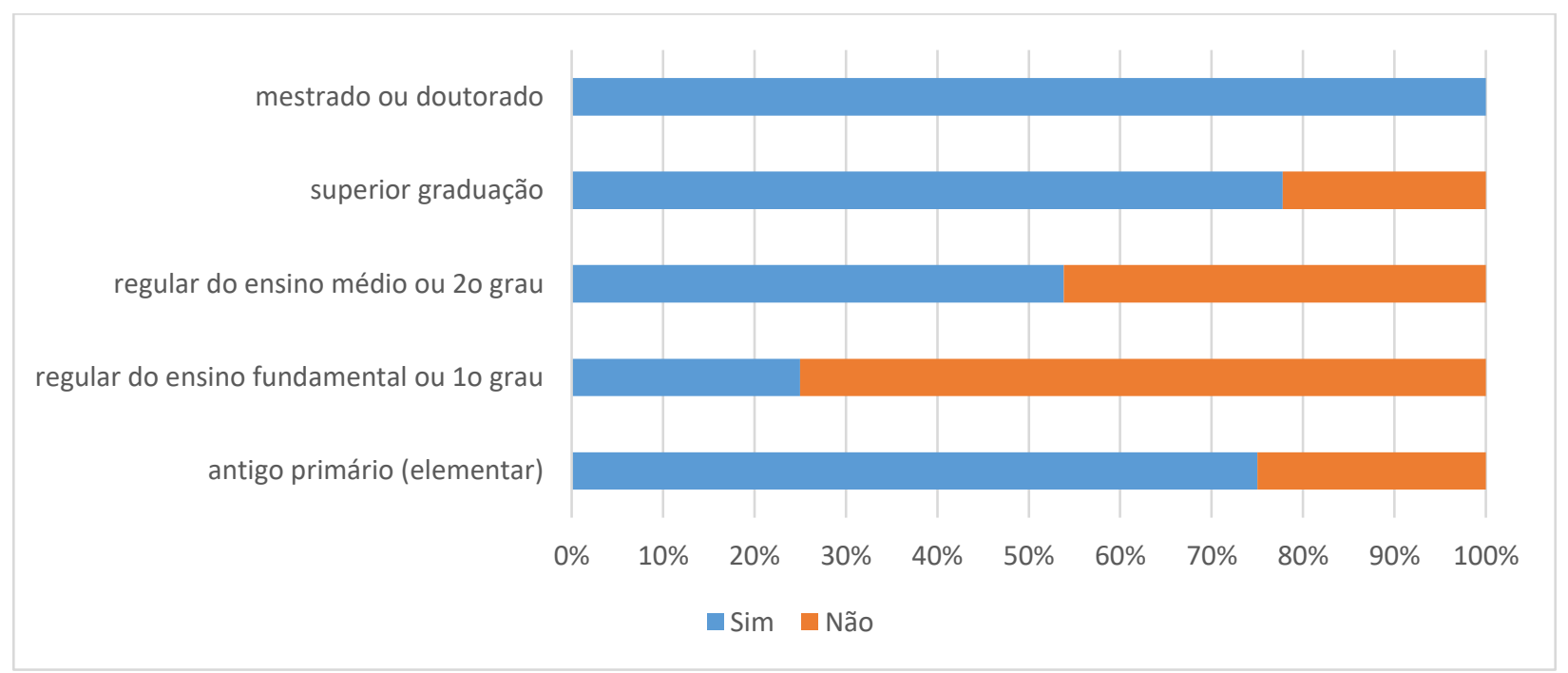

Fonte: Elaborado pelo autor.

A pesquisa também mostrou que quando analisado por categoria (proprietário, gestor profissional, arrendatário ou outro) ao uso de controles por quem faz a gestão, o 
gestor profissional apresentou maior preponderância com $82 \%$ e o arrendatário menor com 33\% (Figura 24).

Figura 24 - Percentual de controles de custos produtivos nos empreendimentos rurais por quem faz a gestão.

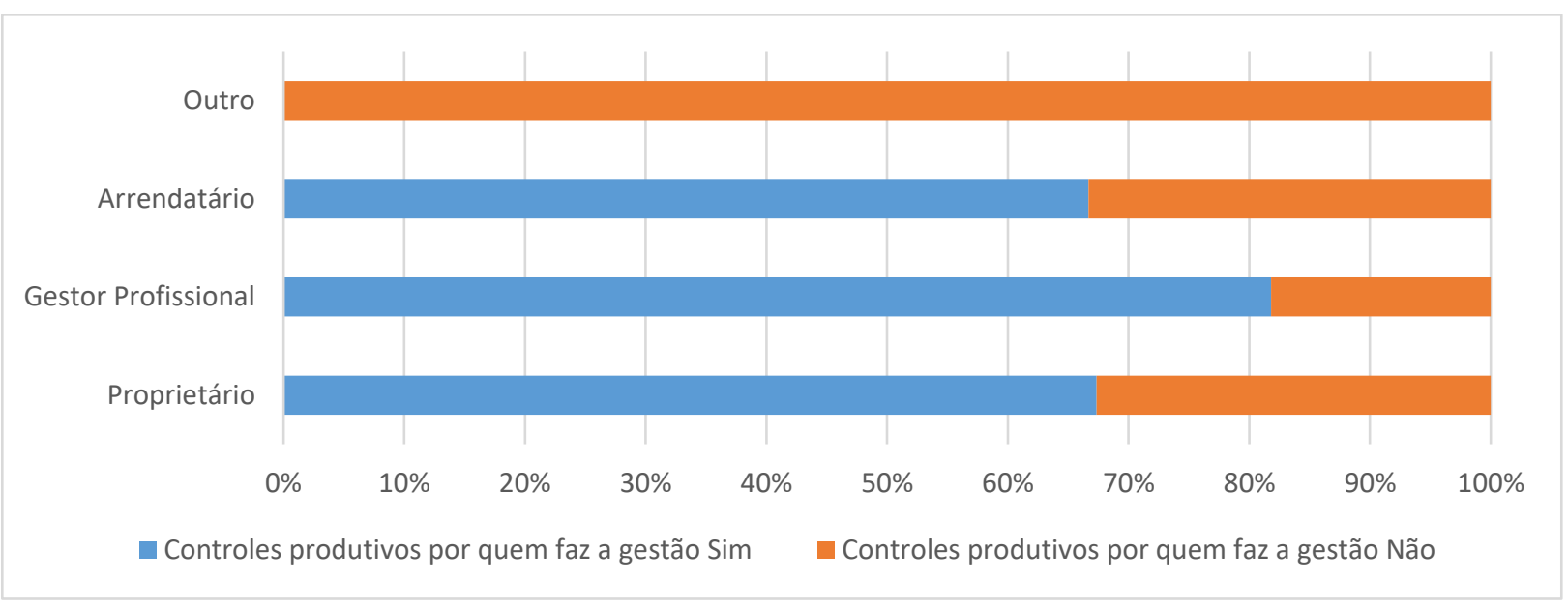

Fonte: Elaborado pelo autor.

Ao final, ao analisar o uso de controles por tipo de cultura agropecuária (pecuária ou agricultura), há uma maior preponderância na pecuária na ordem de 52\% (Figura 25). Figura 25 - Percentual da atividade comerciais com controles de custos produtivos por tipo de cultura agropecuária ${ }^{(1)}$.

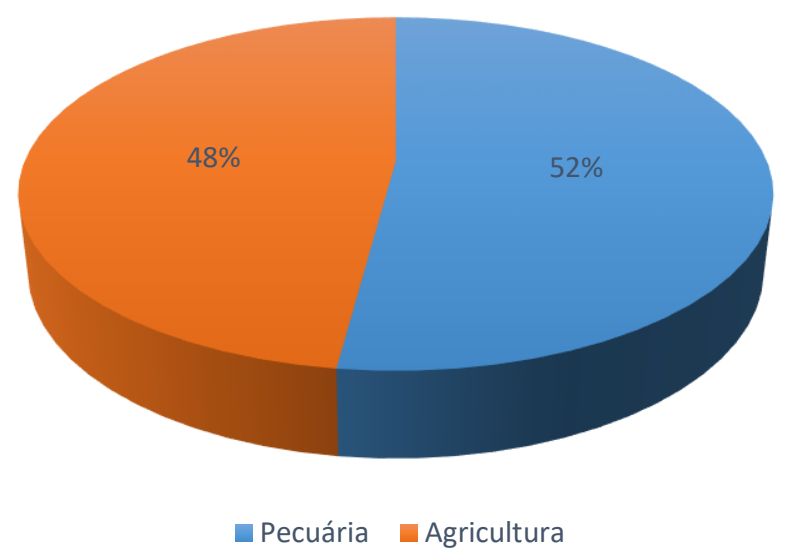

(1) Podem ter múltiplas respostas

Fonte: Elaborado pelo autor. 


\subsection{Tipos e formas de controle e registro das movimentações financeiras nos empreendimentos rurais}

Fontoura e Deponti (2018) ressaltaram o desenvolvimento regional para a agricultura familiar no agronegócio, assim como a necessidade de análise econômica e financeira dos custos nas propriedades rurais inseridos nesta visão interdisciplinar. Verifica-se que $93 \%$ dos empreendimentos rurais possuem algum tipo de controle financeiro, ou seja, conseguem de alguma forma acompanhar o fluxo de entrada e saída de recursos monetários na propriedade. Esse tipo de controle é referenciado por muitos pesquisadores como essencial para a sobrevivência do estabelecimento produtor e para o desenvolvimento regional.

Dos empreendimentos rurais que possuem algum tipo de registro para o controle financeiro utilizado como ferramenta de gestão, 39\% os faz de forma manuscrita, através de caderno de anotações ou cadernetas; 33\% utilizam planilhas de Excel que são alimentadas de forma manual, mas com maior possibilidade de armazenamento e análise dos dados; $17 \%$ registram a movimentação através de sistema computacional ou fichas eletrônicas os quais possibilitam maior segurança no armazenamento, análise e rapidez no cumprimento das obrigações contábeis e fiscais e 7\% não possuem qualquer tipo de controle financeiro (Figura 26).

Figura 26 - Percentual dos tipos de registros das movimentações financeiras utilizados nos empreendimentos rurais por quem faz a gestão.

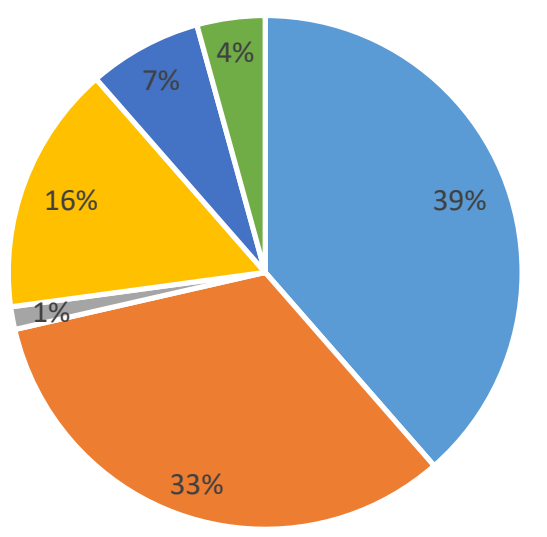

- Caderno de anotações ou cadernetas

- Planilhas de excel

- Fichas eletrônicas

- Sistema computacional

- Não possuem

- Outro

Fonte: Elaborado pelo autor. 
A pesquisa também apontou que os gestores com nível de escolaridade: antigo primário (elementar), regular do ensino fundamental ou $1^{\circ}$ grau e regular do ensino médio ou $2^{\circ}$ grau possuem maior aderência ao tipo de controle em papel: caderno de anotações ou cadernetas com $82 \%$ de uso.

Por outro lado, gestores com nível de escolaridade superior: graduação, mestrado ou doutorado possuem mais aderência aos controles eletrônicos: planilhas de excel, fichas eletrônicas e sistema computacional na ordem de $83 \%$ de uso (Figura 27).

Figura 27 - Percentual dos tipos de registros das movimentações financeiras utilizados nos empreendimentos rurais por nível de escolaridade de quem faz a gestão.

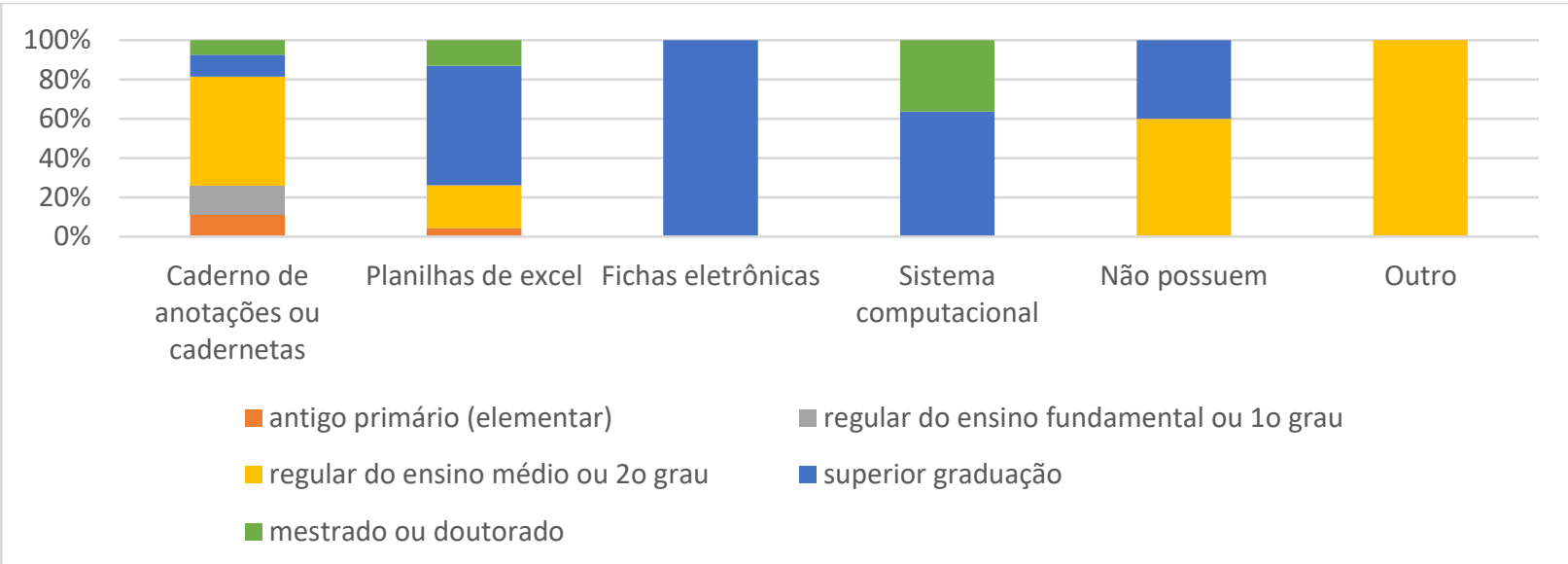

Fonte: Elaborado pelo autor.

Quando se associam os tipos de controles financeiros utilizados por quem a gestão nos empreendimentos rurais, considerando a atividade, produto ou serviço, assim compreendidos como pecuária ou agricultura verifica-se que na pecuária, dos que possuem registro das movimentações financeiras, $60 \%$ os faz de forma eletrônica e $33 \%$ de forma manuscrita. Na agricultura $61 \%$ de forma eletrônica e $39 \%$ de forma manuscrita. Dos que não registram, $80 \%$ estão concentrados na agricultura (Figura 28). 
Figura 28 - Percentual dos tipos de registros das movimentações financeiras utilizados nos empreendimentos rurais por nível de escolaridade de quem faz a gestão.

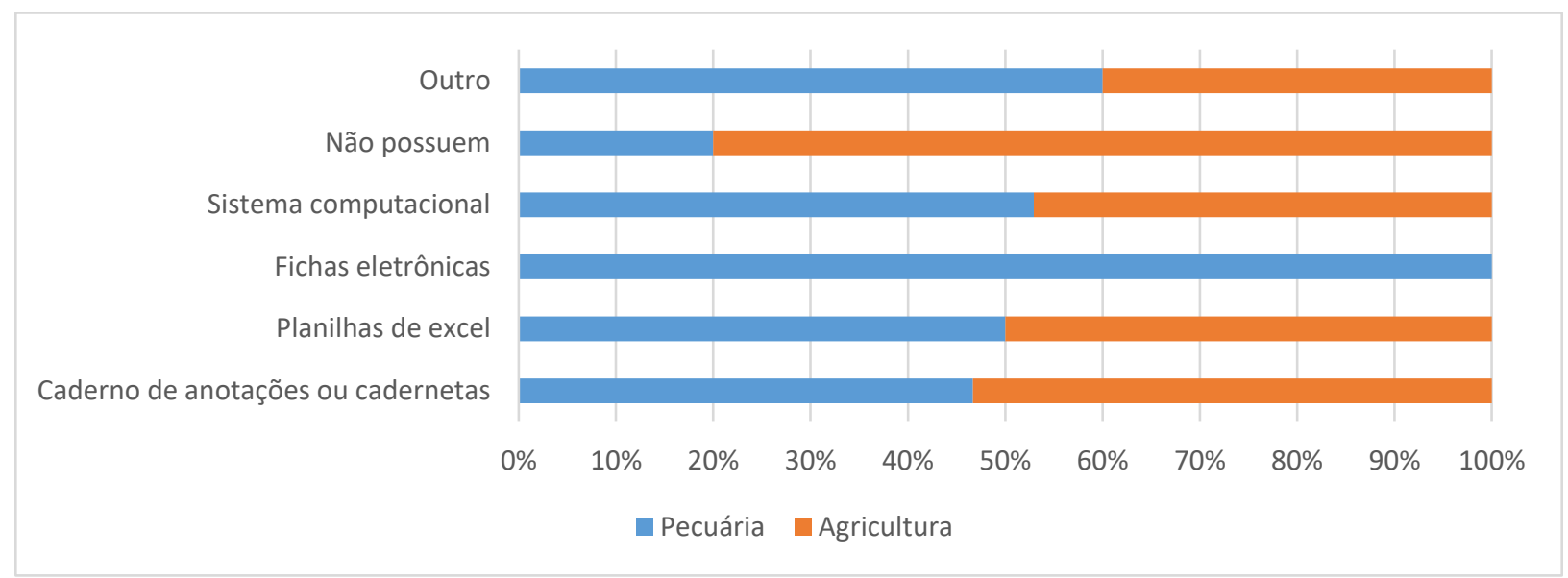

(1) Podem ter múltiplas respostas

Fonte: Elaborado pelo autor.

A legislação tributária e contábil brasileira impõe algumas considerações quanto a evidenciação das movimentações nas empresas, inclusive na atividade rural, o qual se preocupa com o registro, guarda e integridade das informações para auxílio no processo decisório e ou para fins de fiscalização perante o ente público.

Entre os meios para efetuar o registro das movimentações financeiras na atividade rural, utilizam-se, entre outros, o livro caixa e a contabilidade através dos seus demonstrativos patrimoniais e de resultado. Neste sentido, a pesquisa apontou que $50 \%$ dos gestores dos empreendimentos rurais utilizam o livro caixa, $21 \%$ a contabilidade, $16 \%$ não registram e $13 \%$ outros meios (Figura 29). 
Figura 29 - Percentual das formas de registro das movimentações financeiras utilizados nos empreendimentos rurais por quem faz a gestão.

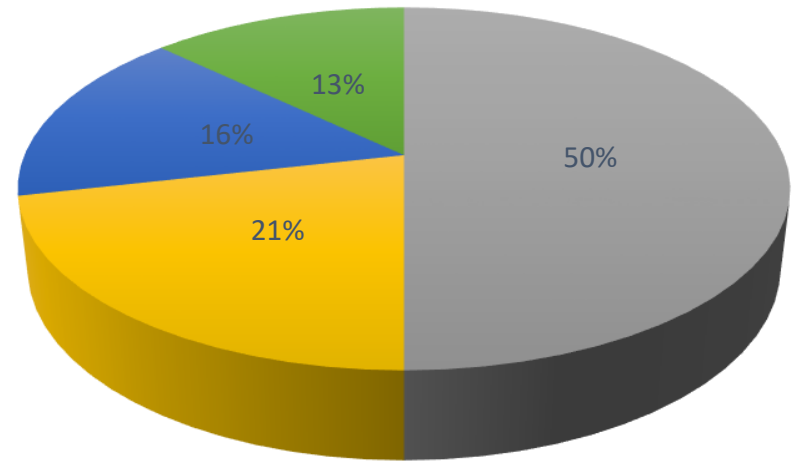

Livro Caixa

Contabilidade

- Não registra

Outro

Fonte: Elaborado pelo autor.

Aspectos relacionados ao montante de receita auferida na atividade rural também é uma das condicionantes em utilizar o livro caixa (informações mais resumidas) ou a contabilidade (que é meio mais completo e rico de informações) para a tomada de decisão. Outra variável é o tamanho da propriedade e o respectivo fluxo de informações operacionais, financeiras, de pessoas entre outras para assim, optar entre o uso do livro caixa ou a contabilidade.

Desta forma, os empreendimentos rurais com mais de 50 hectares e com diversidade de culturas apresentaram maior aderência ao uso da contabilidade e os de única cultura o livro caixa ou outra forma. Dos que não efetuam o registro $87 \%$ possuem menos de 50 hectares (Figura 30). 
Figura 30 - Formas de registro das movimentações financeiras nos empreendimentos rurais por tamanho em hectares

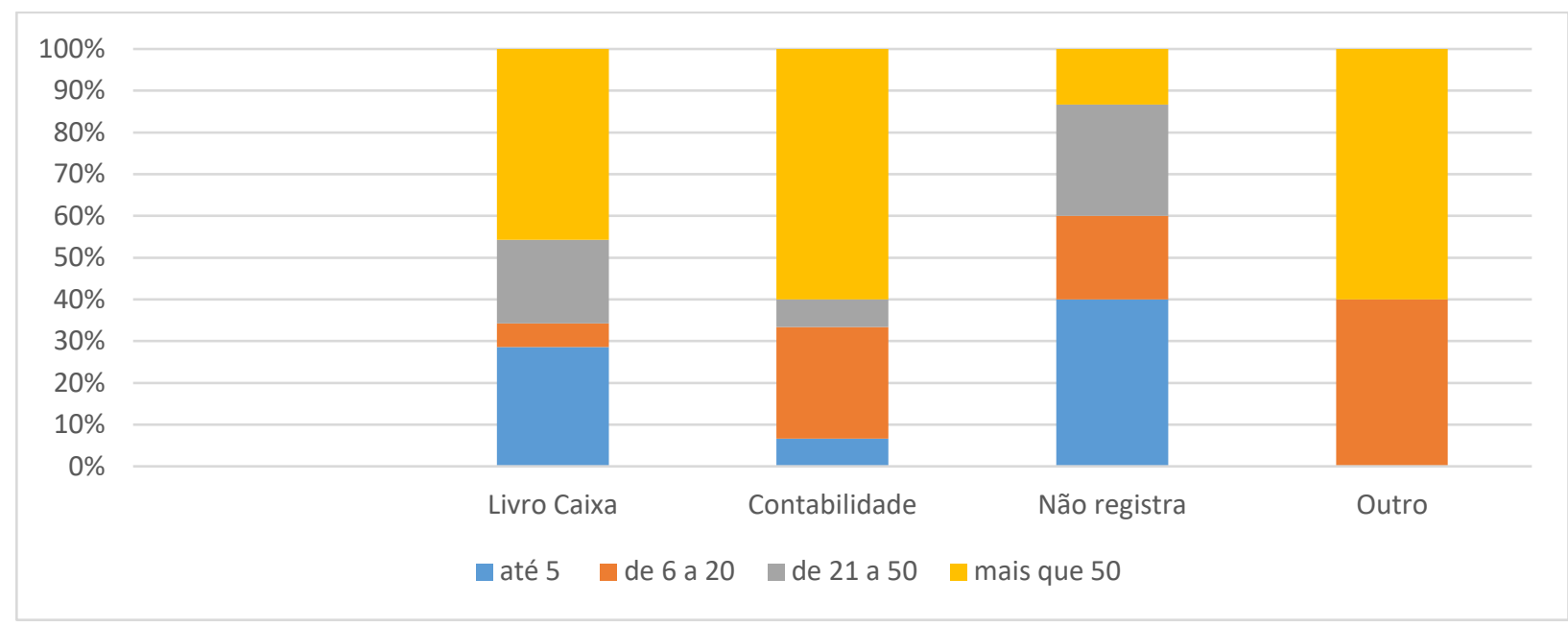

Fonte: Elaborado pelo autor.

Quando o produtor opta por registrar as movimentações financeiras através do livro caixa, pode realizar no próprio local do empreendimento rural ou em escritório externo de contabilidade. Ao contrário do livro caixa, ao optar pelo registro contábil e caso não tenha um software ou estrutura interna, precisa fazê-lo em ambiente externo à propriedade, ou seja, num escritório de contabilidade.

A pesquisa apontou que dos empreendimentos rurais onde há o registro das movimentações financeiras via livro caixa, $71 \%$ efetuam o registro no próprio empreendimento rural e $29 \%$ em escritório externo de contabilidade ou outro meio.

Por outro lado, dos que utilizam via contabilidade, $35 \%$ registram no próprio empreendimento rural e $64 \%$ em escritório externo de contabilidade ou outro meio (Figura 31). 
Figura 31 - Local de registro das movimentações financeiras dos empreendimentos rurais

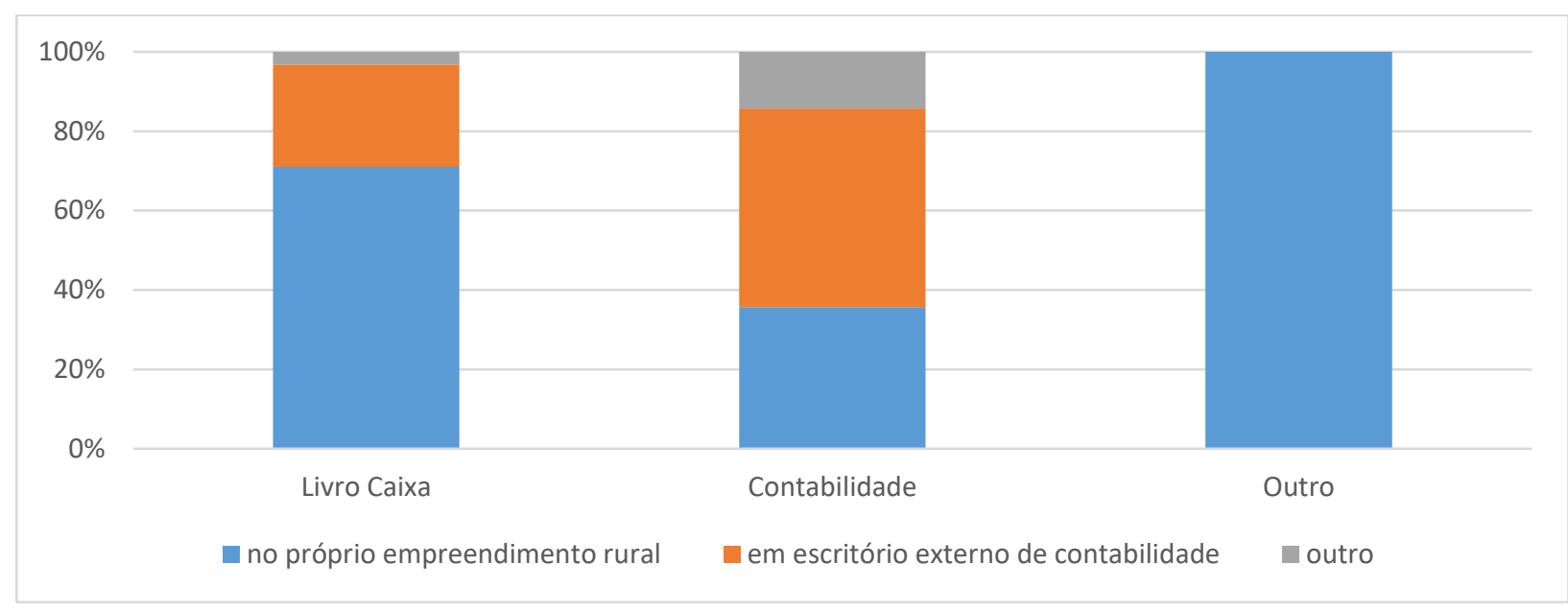

Fonte: Elaborado pelo autor.

\subsection{Regimes tributários praticados na comercialização dos produtos ou serviços nos empreendimentos rurais}

A legislação tributária brasileira propõe e em outras, impõe algumas possibilidades ou regimes tributários face a um conjunto de dispositivos legais nas esferas municipais, estaduais ou federais, levando em consideração à atividade econômica, produto ou serviço comercializados, faturamento, quadro societário, entre outros.

Algumas destas opções de tributação podem influenciar positivamente ou negativamente o resultado financeiro dos empreendimentos rurais. Entre as opções de regimes tributários, alguns são menos onerosos e burocráticos como o imposto de renda da pessoa física ou o simples nacional. Por outro lado, há regimes tributários com maior tendência para onerosidade e burocracia como o lucro real ou lucro presumido. A pesquisa apontou que $76 \%$ dos gestores optaram pelo regime tributário do imposto de renda da pessoa física como a melhor opção para tributar as comercializações de produtos ou serviços (Figura 32). 
Figura 32 - Percentual dos regimes tributários adotados nos empreendimentos rurais por quem faz a gestão

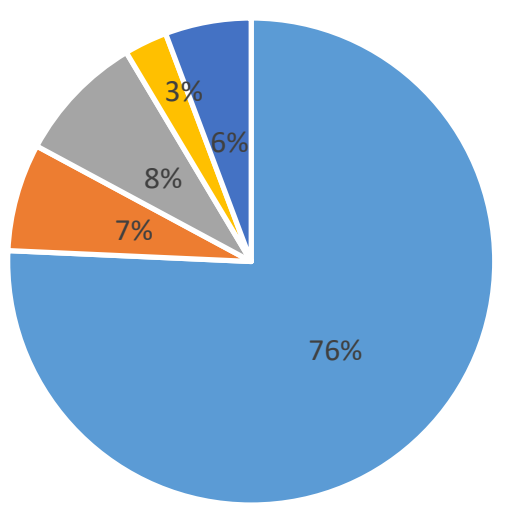

- Imposto de renda da pessoa física

- Simples nacional

- Lucro real

- Lucro presumido

- Outro

Fonte: Elaborado pelo autor.

Figura 33 - Percentual dos regimes tributários adotados em empreendimentos rurais por tamanho em hectares

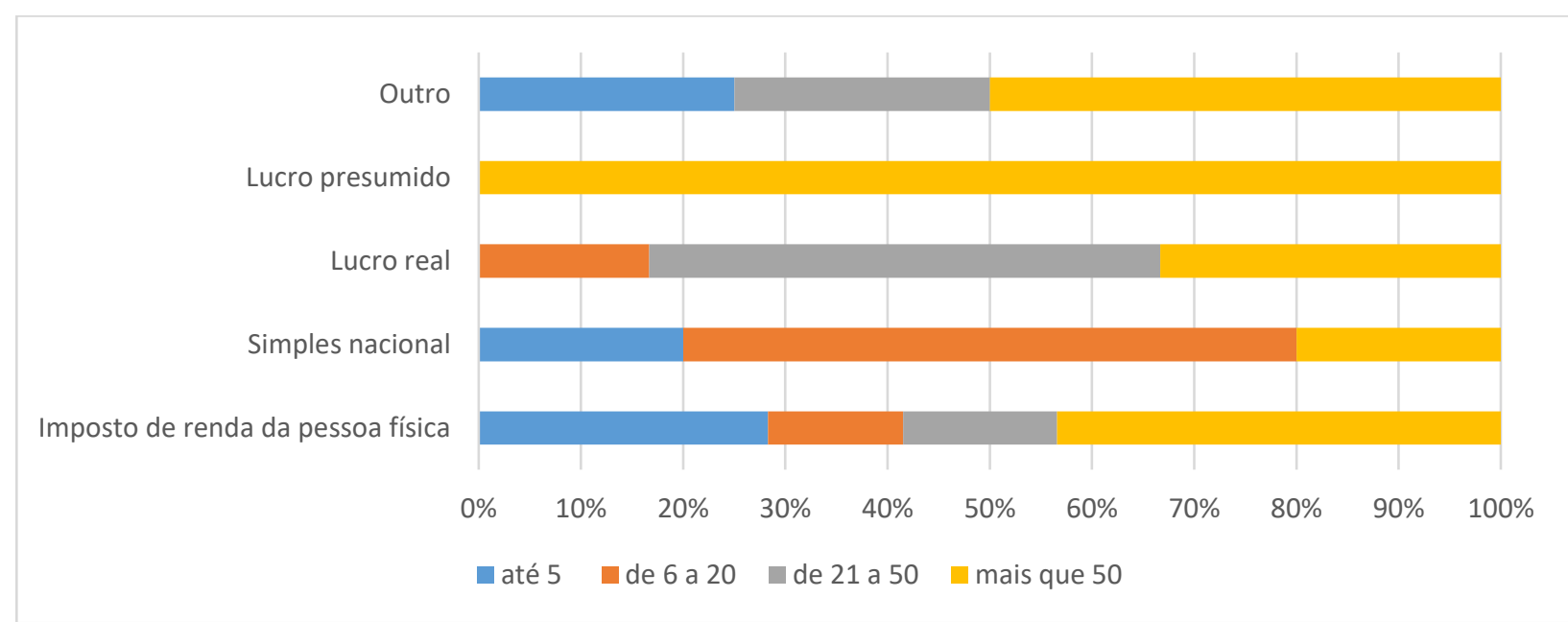

Fonte: Elaborado pelo autor.

Dos empreendimentos rurais que tributam suas operações através do imposto de renda da pessoa física, $56 \%$ possuem menos que 50 hectares. Ao contrário das propriedades que possuem mais de 21 hectares, as menores (até 5 hectares) não apresentaram aderência aos regimes tributários: lucro real e lucro presumido, onde são mais propensos às atividades com maior fluxo de informação e faturamento, além da 
prática de planejamento tributário, onde se estuda a possibilidade legal (elisão fiscal) de menos ônus tributário na atividade rural (Figura 33).

\subsection{Principais informações ou índices levados em consideração no auxílio à tomada de decisão na comercialização dos produtos ou serviços nos empreendimentos rurais}

O processo decisório nas organizações envolve diversas variáveis entorno dos produtos ou serviços comercializados, como clima, mercado e preço, marketing, finanças, informações técnicas, entre outras. Essas informações são extremamente importantes para a condução dos negócios e diferenciais para o desenvolvimento sustentável do fluxo de caixa. Neste sentido, procurou-se identificar se os gestores dos empreendimentos rurais possuem alguma forma de orientação para a condução das atividades. Uma quantidade significativa, cerca de 93\%, acompanham algum tipo de informação ou índices como auxílio no processo decisório, com maior preponderância a cotação de mercado ou commodities e climáticos com $27 \%$ cada; $15 \%$ utilizam o fluxo de caixa como fator decisório; $13 \%$ variáveis técnicas relacionadas ao manejo animal e $7 \%$ ao cultivo vegetal.

Dos que não se baseiam em alguma fonte de informação os faz de forma empírica, ou seja, pela intuição ou experiência no negócio, cerca de 1\% (Figura 34).

Figura 34 - Percentual das informações ou índices levados em consideração para a tomada decisória nos empreendimentos rurais
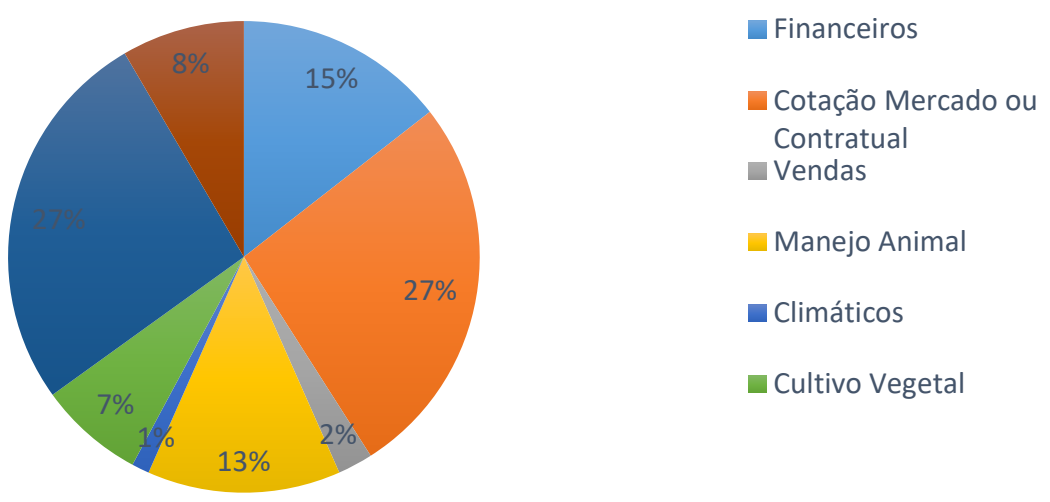

Fonte: Elaborado pelo autor. 
Outro aspecto observado foi o de entender a influência do nível de educação de quem faz a gestão nos empreendimentos rurais frente ao uso de informações para apoio ao processo decisório.

Quem tem nível inferior ao de graduação, mestrado ou doutorado, apresentaram mais preponderância ao uso de informações de ordem empírica, climático ou não utilizam nenhuma informação. Ao contrário, dos de nível superior utilizam informações financeiras, cotação de mercado ou preço, manejo animal e cultivo vegetal (Figura 35).

Figura 35 - Percentual das informações ou índices levados em consideração para a tomada decisória nos empreendimentos rurais por nível de formação de quem faz a gestão

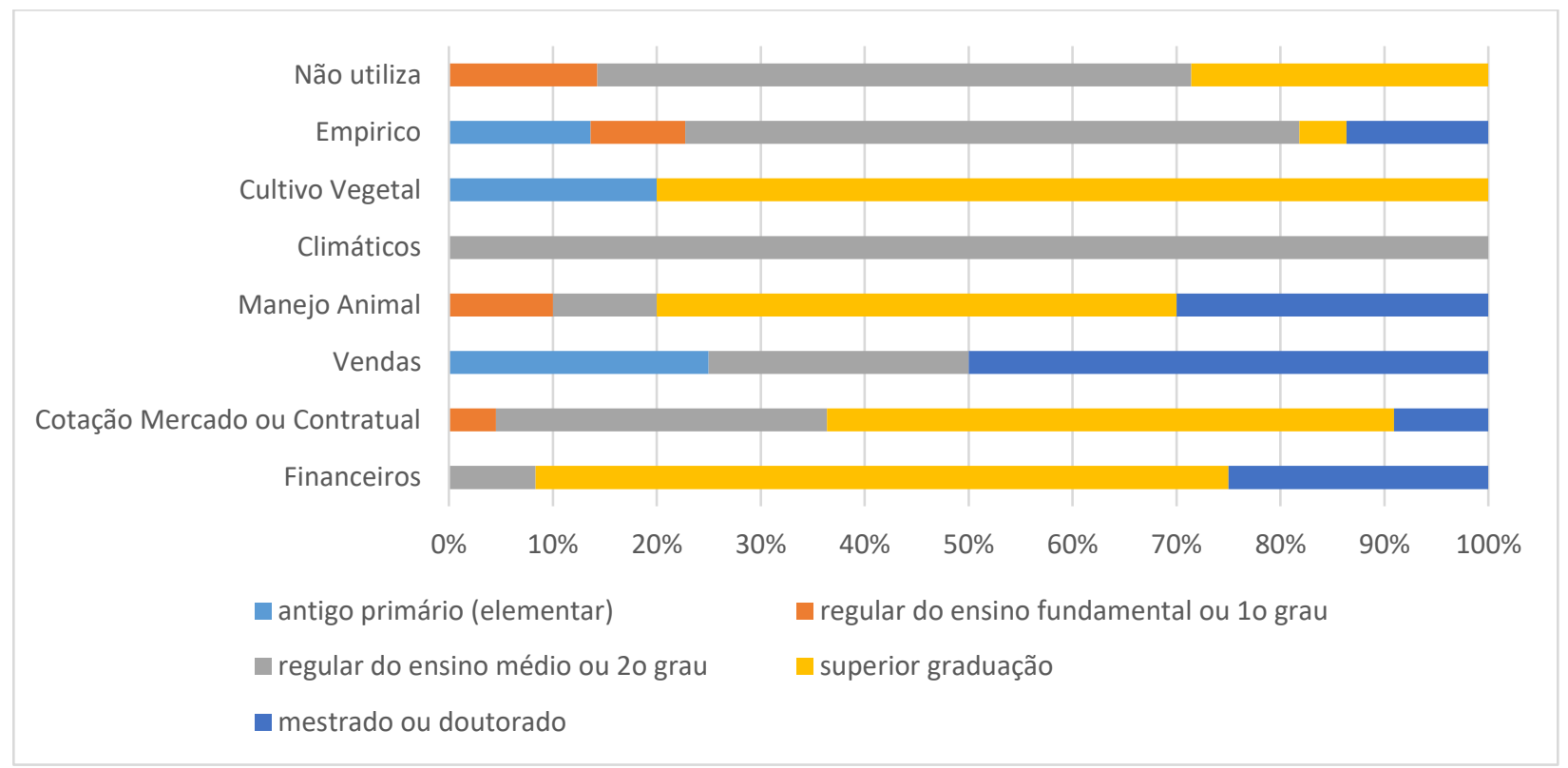

Fonte: Elaborado pelo autor.

\subsection{Nível de percepção quanto ao resultado (lucro) dos empreendimentos rurais nos últimos 5 anos e principais variáveis influenciáveis}

Independentemente do tipo de negócio, o lucro é uma métrica de mensuração financeira para saber se todo o esforço aplicado na operacionalidade foi satisfatório ou não. Também, serve de parâmetro para decidir a permanência no segmento ou não. 
Desta forma, a pesquisa procurou identificar como o gestor se comporta com esta situação e quais fatores ou variáveis que impactaram positivamente ou negativamente na operacionalidade dos empreendimentos rurais.

Considerando o contexto dos últimos 5 anos, 36\% relataram que, de alguma forma, está melhorando, através de investimentos em tecnologia e agricultura de precisão, devido a forma de gerir o negócio, melhoria nas técnicas de manejo animal e no cultivo vegetal, flutuação cambial, preço das commodities, entre outras.

Dos que alegam estar piorando, $29 \%$ atribuiu a questões de altos custos com insumos e maquinários, deficiência na gestão de fluxo de caixa, produtos agroquímicos muito altos, baixo preço pago pelos frigoríficos ou cooperativas, entre outras. Os que consideram estar estáveis, cerca de $24 \%$, alegam que a variável preço e mercado tiveram altos e baixos e isso equilibraram o fluxo de caixa nos últimos 5 anos. Por final, $11 \%$ não souberam responder (Figura 36).

Figura 36 - Percentual de percepção dos gestores dos empreendimentos rurais com o lucro nos últimos 5 anos

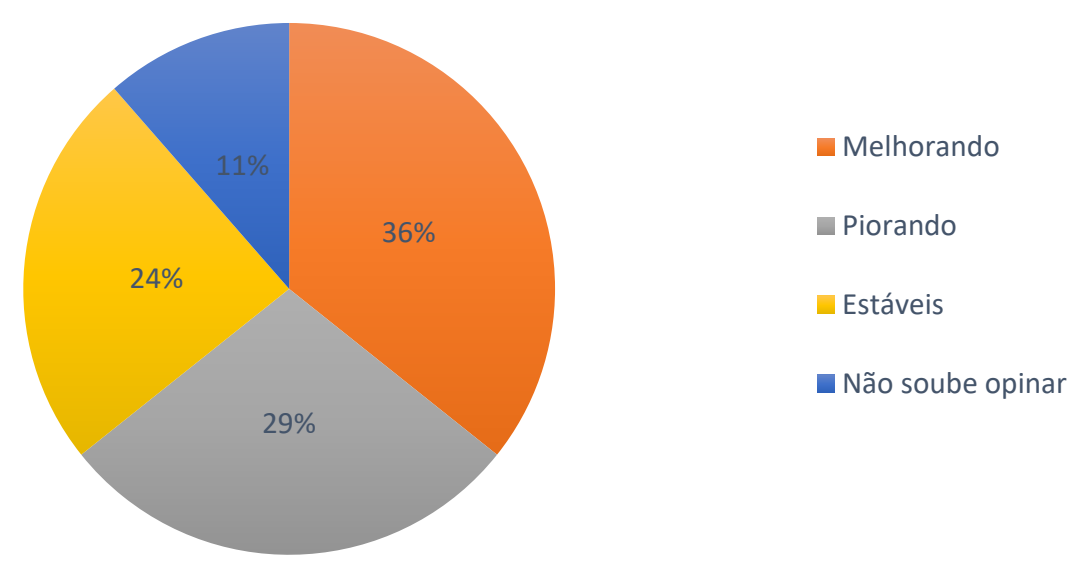

Fonte: Elaborado pelo autor.

De fato, muitas variáveis influenciam positivamente ou negativamente o resultado de uma empresa, e o gestor pode ou não tem domínio sobre isso como por exemplo aspectos climáticos, políticos, econômicos, operacionais, entre outros. Procurando 
entender essa questão, a pesquisa apontou, de forma resumida, algumas destas variáveis que influenciaram positivamente nos resultados nos últimos 5 anos.

Mercado, aqui com o entendimento como relação de consumo: cliente e fornecedor, foi na opinião de $44 \%$ dos gestores a principal variável. Aspectos relacionados a investimentos, sejam esses ligados à tecnologia, processos ou técnicas de manejo animal ou cultivo vegetal se constituíram como os que mais influenciaram, segundo $33 \%$ dos gestores. Ademais, aspectos ligados à gestão, ou seja, administração dos recursos humanos, financeiros, materiais ou marketing tiveram, na opinião de $17 \%$ dos gestores, influência positiva. De menor relevância, $3 \%$ responderam variáveis ligadas a clima e economia (Figura 37).

Figura 37 - Percentual das variáveis que influenciaram positivamente no lucro dos empreendimentos rurais ${ }^{(1)}$

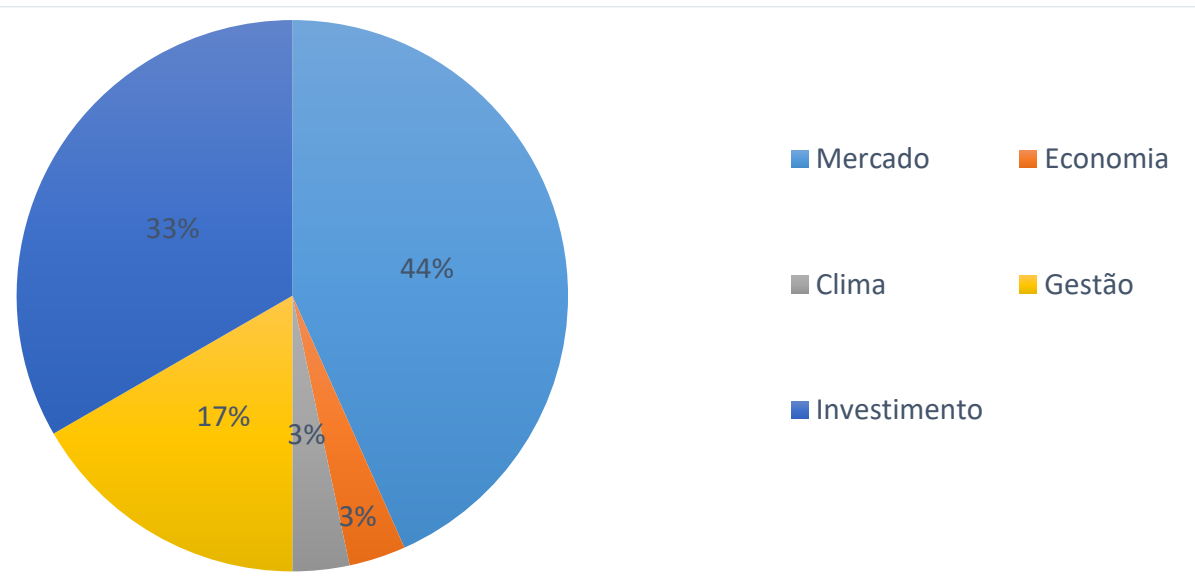

(1) Podem ter múltiplas respostas

Fonte: Elaborado pelo autor.

Assim como visto anteriormente, houve variáveis que impactaram positivamente no lucro nos últimos 5 anos, contudo, a pesquisa também apontou o contrário, ou seja, as mesmas variáveis, em situações adversas, não ajudaram a obter ou melhorar o lucro nos empreendimentos rurais. Neste sentido, os gestores apontaram que ausência de investimentos, seja por questões de acesso ao crédito, baixa percepção de visão futura e, em alguns casos, a demora para obter o retorno do capital investido, foi o principal 
motivo que influenciou negativamente o lucro, segundo $28 \%$ dos depoimentos. Seguindo essa tendência, o comportamento de mercado e a ausência de gestão profissional tiveram forte influência negativa no lucro, segundo $24 \%$ em ambos os depoimentos (Figura 38).

Figura 38 - Percentual das variáveis que influenciaram negativamente no lucro dos empreendimentos rurais ${ }^{(1)}$

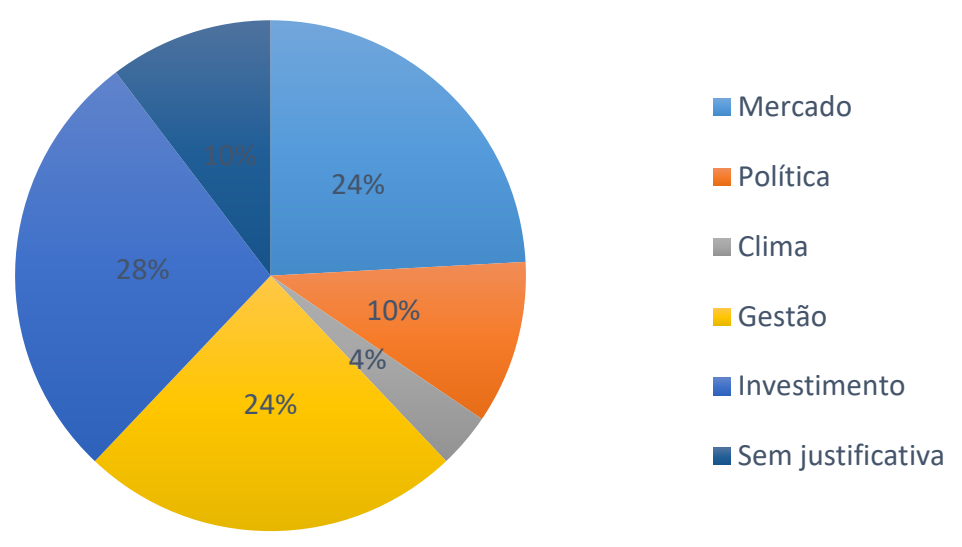

(1) Podem ter múltiplas respostas

Fonte: Elaborado pelo autor.

Como apontado anteriormente, a variável ligada ao mercado tem importância significativa no momento da tomada de decisão, seja para adequação nos processos operacionais face ao preço imposto pelo mercado (commodities) ou de características regionais.

Assim, como visto anteriormente, o comportamento mercadológico pode ter influência positiva ou negativa no lucro dos empreendimentos rurais. Face a essas prerrogativas, foi constatado na pesquisa que $93 \%$ dos gestores acompanham preços e informações de comportamento de mercado (Figura 39). 
Figura 39 - Percentual dos gestores de empreendimentos rurais que acompanham preços e informações sobre o comportamento de mercado.

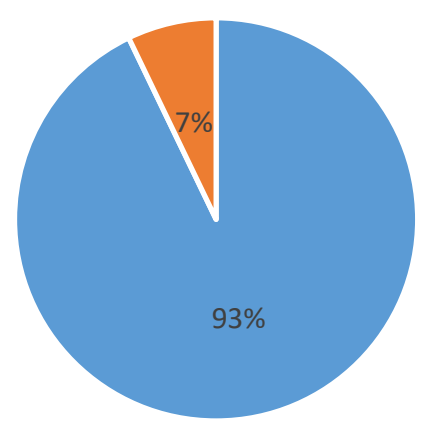

• Sim — Não

Fonte: Elaborado pelo autor.

Como meio de acompanhamento do comportamento de mercado e preços, $54 \%$ dos gestores de empreendimentos rurais utilizam sites especializados ou noticiários pela internet.

Ademais, 14\% acompanham através da TV como, por exemplo, Canal Rural ou Globo Rural. Alguns através de boletins eletrônicos recebidos através de e-mail, cerca de $13 \%$, e em uma menor proporção, através de associações ou cooperativas locais e feiras de exposições (Figura 40).

Figura 40 - Percentual das fontes utilizadas para acompanhamento de preços e informações sobre comportamento de mercado nos empreendimentos rurais.

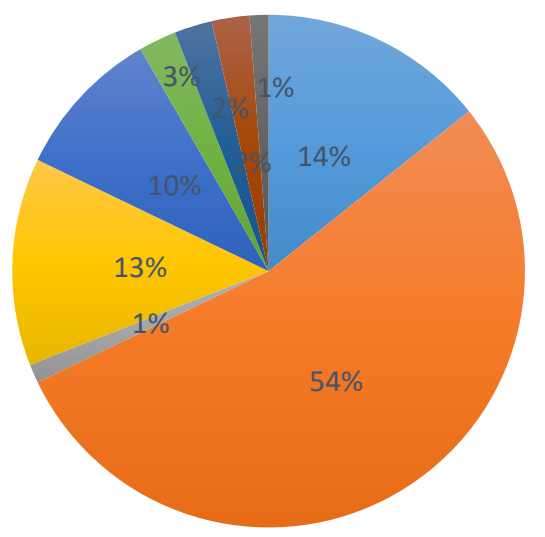

$\square \mathrm{TV}$

- Sites especializados ou noticiários pela internet

- Aplicativos

email - Boletins Eletrônicos

- Associações ou Cooperativas - locais

- Feiras de exposição

- Consultorias Presenciais

- Outros Produtores

- Palestras ou Treinamentos

Fonte: Elaborado pelo autor. 
Olhar o passado é importante e ajuda a projetar o futuro. Contudo, não é o essencial. Atrelado a experiências vividas, a combinação com as fontes de informações inerentes a atividade rural, sejam essas, de comportamento de mercado, preço, clima, entre outras; ajudam o gestor a ter parâmetros para traçar um norte quanto ao futuro, que é incerto, mas que pode ser de alguma forma planejado.

Neste sentido, a pesquisa procurou identificar se o gestor do empreendimento rural tem percepção quanto a tendência de futuro, ou seja, qual a observação futura quanto ao mercado que estão inseridos.

A maioria, ou seja, $61 \%$ relataram que estão otimistas e que o mercado se projeta promissor. Em uma proporção menor, 26\% estão pessimistas e que o mercado é incerto. Por fim, $9 \%$ não conseguem enxergar e $4 \%$ não sabem opinar (Figura 41 ). Desses, os mais otimistas quanto ao futuro são os produtores com menor nível de estudo formal (Figura 42).

Figura 41 - Percentual de observação dos gestores dos empreendimentos rurais quanto ao mercado que estão inseridos (visão futura).

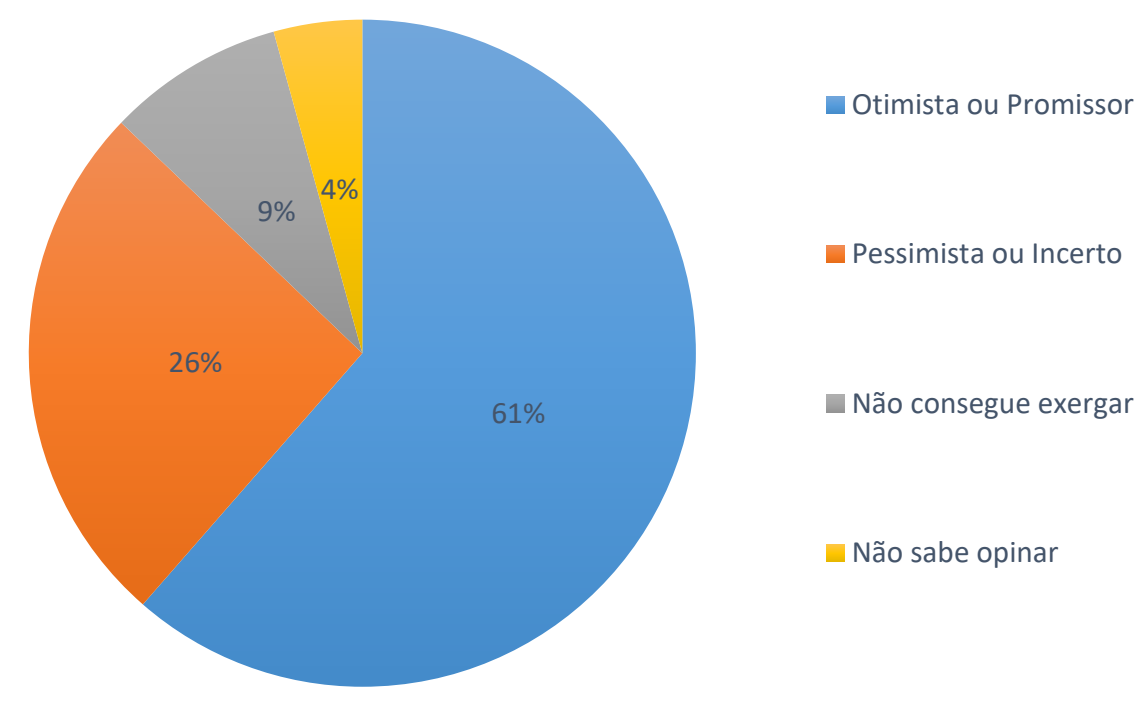

Fonte: Elaborado pelo autor. 
Figura 42 - Percentual de observação dos gestores dos empreendimentos rurais quanto ao mercado que estão inseridos (visão futura) por nível de escolaridade de quem faz a gestão.

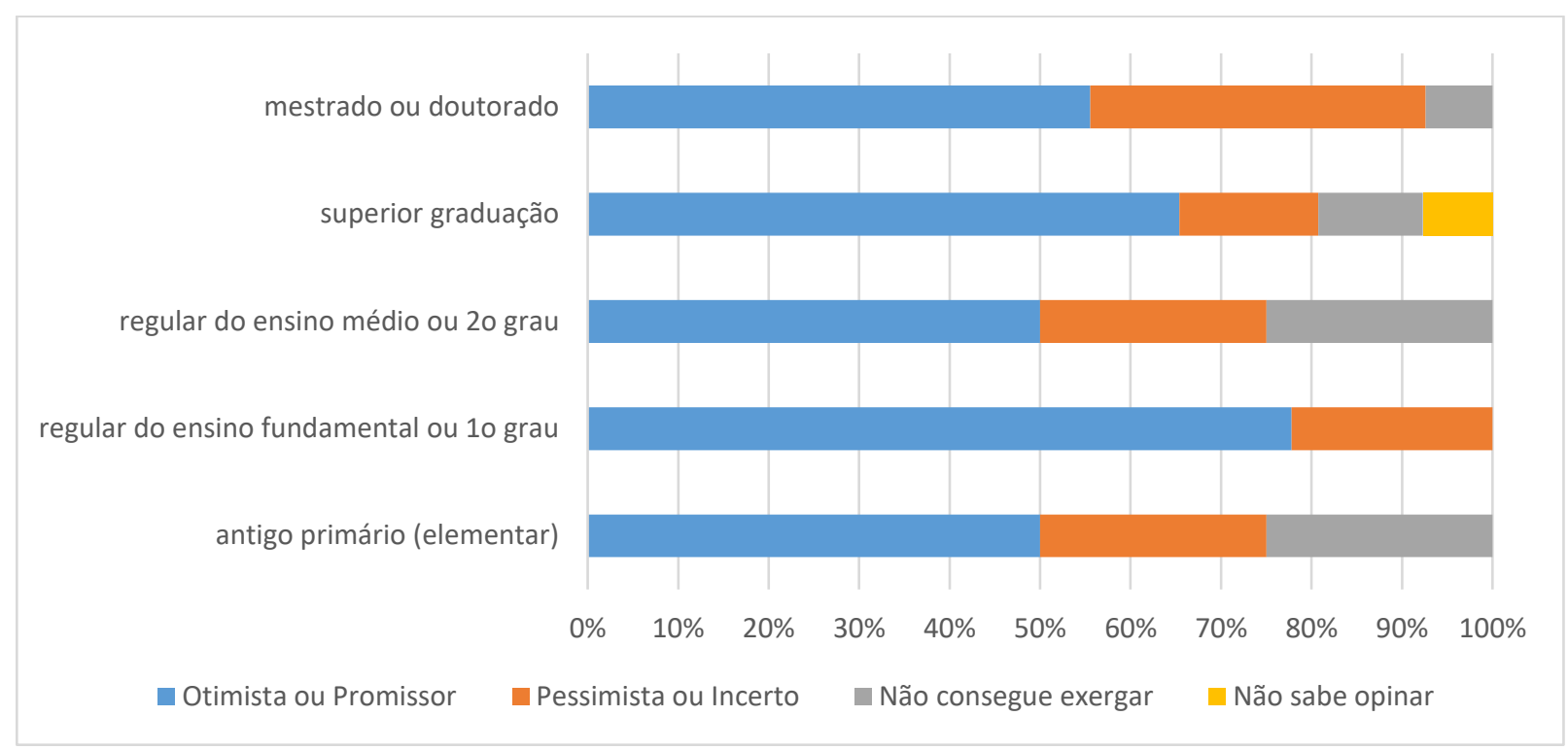

Fonte: Elaborado pelo autor.

\subsection{Nível de carência por serviço de gestão nos empreendimentos rurais e predisposição em conhecer novas ferramentas de apoio à gestão}

A busca por informações que possam servir de apoio ao processo de gestão tem sido uma alternativa muito eficaz nos empreendimentos rurais, em virtude da facilidade ao acesso por meio da internet e pela qualidade dos materiais publicados em sites especializados.

Além disso, diversos treinamentos e cursos presenciais têm sido responsáveis pela disseminação do conhecimento através de diversos centros de pesquisa, universidades, associações cooperativas, profissionais liberais ou empresas de consultoria, entre outros.

Com relação a este aspecto, a pesquisa apontou que $94 \%$ dos gestores de empreendimentos rurais tem carência por algum tipo de serviço relacionado à 
informação: marketing, gestão de pessoas, contabilidade, finanças, gestão de risco, automação, técnico de pragas, manejo sanitário, custo produtivo entre outros (Figura 43).

Figura 43 - Percentual de carência por serviço de gestão nos empreendimentos rurais.

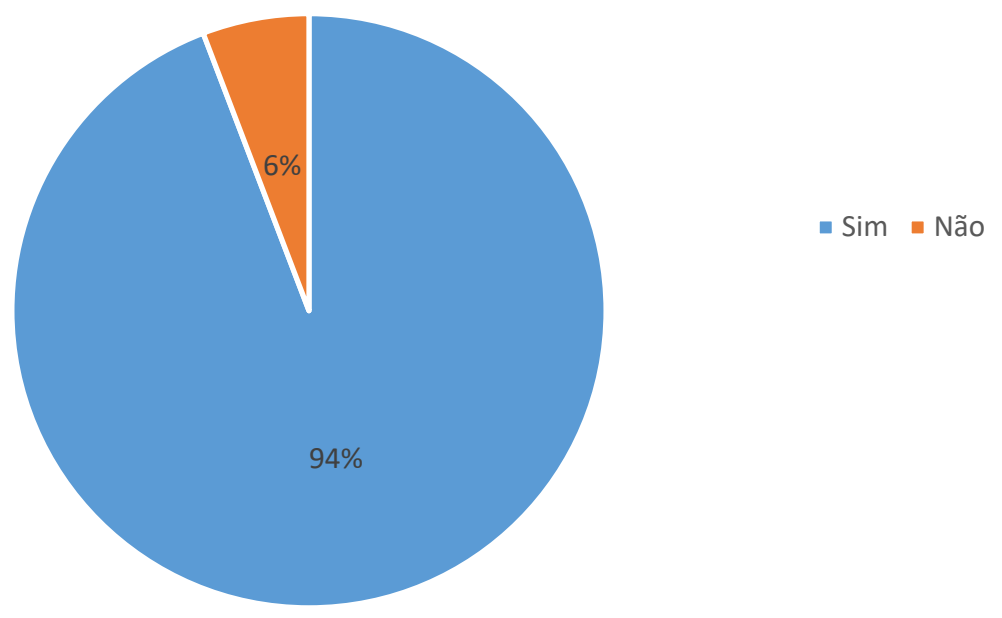

Fonte: Elaborado pelo autor.

Além da predisposição do gestor dos empreendimentos rurais por serviços que visam melhorar processos operacionais para buscar uma maior eficiência na geração de recursos financeiros, entendimento e suporte nas relações humanas no trabalho, compreender comportamento de mercado, bem como, a relação custo do produto ou serviço e o respectivo preço praticado, $91 \%$ dos entrevistados se manifestaram estar dispostos em conhecer uma proposta de gestão que viesse a contribuir na tomada decisória nos empreendimentos rurais (Figura 44).

Esta ferramenta, aqui chamada de Nav Agro Brasil, se caracteriza como uma proposta de ferramenta remota de gestão para controle e auxílio às tomadas de decisão na área financeira/contábil em empreendimentos rurais, vis-à-vis o acesso à rede de computadores. Esse resultado consolida a demonstração pela demanda em relação a uma ferramenta com esse propósito. 
Figura 44 - Percentual de gestores dispostos a conhecer uma proposta de sistema de gestão que visse a contribuir na tomada decisória nos empreendimentos rurais.

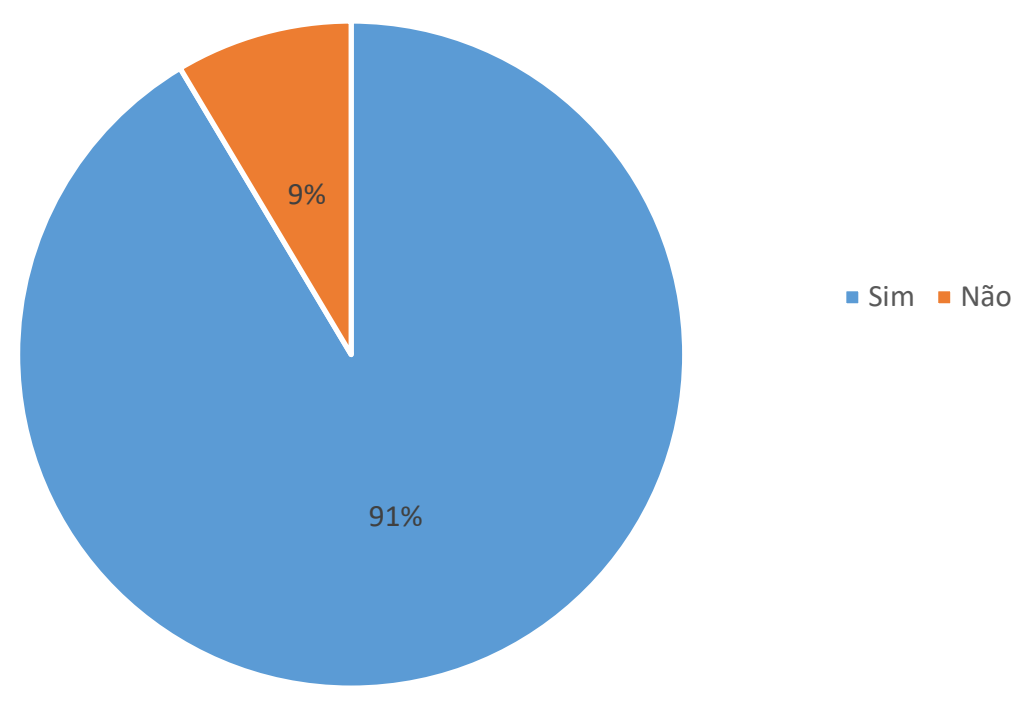

Fonte: Elaborado pelo autor.

\subsection{Acesso à rede de computadores no Brasil pelos gestores dos empreendimentos rurais}

Redes de computadores são como auto pistas por onde trafegam, no âmbito mundial, informações eletrônicas dos mais variados tipos, incluindo textos, figuras, sons e imagens. Para o mundo globalizado - o mundo das redes de computadores - não existem fronteiras entre países, assim como também não há distinção de raça, sexo, cor ou nacionalidade entre pessoas (UFMG, 2020).

No campo não é diferente, contudo, há vários limitadores ao acesso: características regionais, preço do serviço de internet; além de aspectos de natureza sócio cultural como o nível de escolaridade, classe social e a localização do domicílio.

Além disso, as políticas públicas voltadas à universalização da banda larga no Brasil ainda enfrentam o enorme desafio de reduzir ou até mesmo eliminar as desigualdades do acesso à Internet em domicílios de baixa renda e da área rural (CETIC, 
2018). Neste sentido, a pesquisa apontou que $97 \%$ dos gestores dos empreendimentos acessam a rede de computadores, $50 \%$ faz a conexão fora da propriedade e $47 \%$ na propriedade. Dos que não possuem, $3 \%$ pretendem adquirir em um momento futuro (Figura 45).

Figura 45 - Percentual de empreendimentos rurais com acesso à internet.

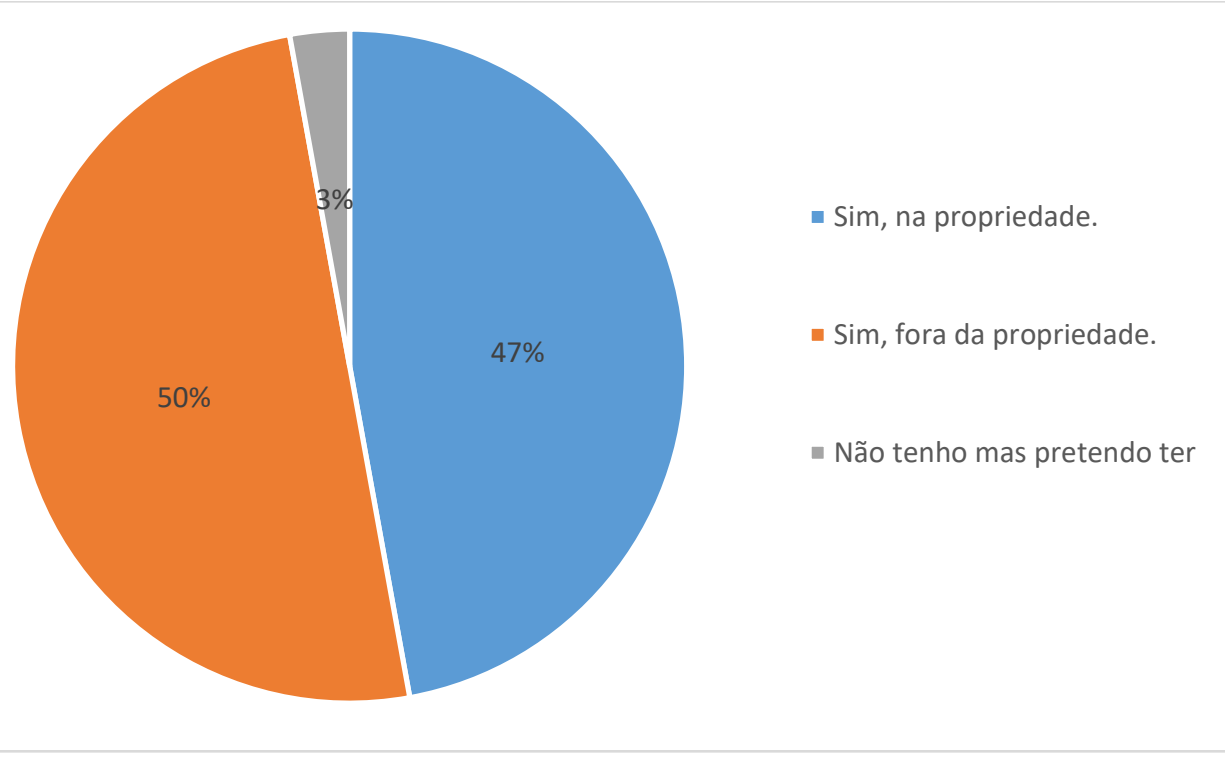

Fonte: Elaborado pelo autor.

Por outro lado, embora haja diferenças de taxas da conectividade entre áreas urbanas e rurais, o aumento da penetração do serviço de banda larga móvel em zonas rurais e o impacto de programas de conectividade rural, efetivados em diversos Estados e regiões, tem indicado que há muito a se fazer, mas sinaliza uma oportunidade de conectividade em áreas remotas (CETIC, 2018).

Assim, para se realizar a conexão, a pesquisa apontou que $36 \%$ utilizam banda larga tipo móvel - via modem ou chip $3 G$ ou $4 G, 27 \%$ via rádio, $14 \%$ via linha telefônica (DSL) e via cabo de tv ou fibra óptica (Figura 46). 
Figura 46 - Tipos de conexões para o acesso à internet nos empreendimentos rurais.

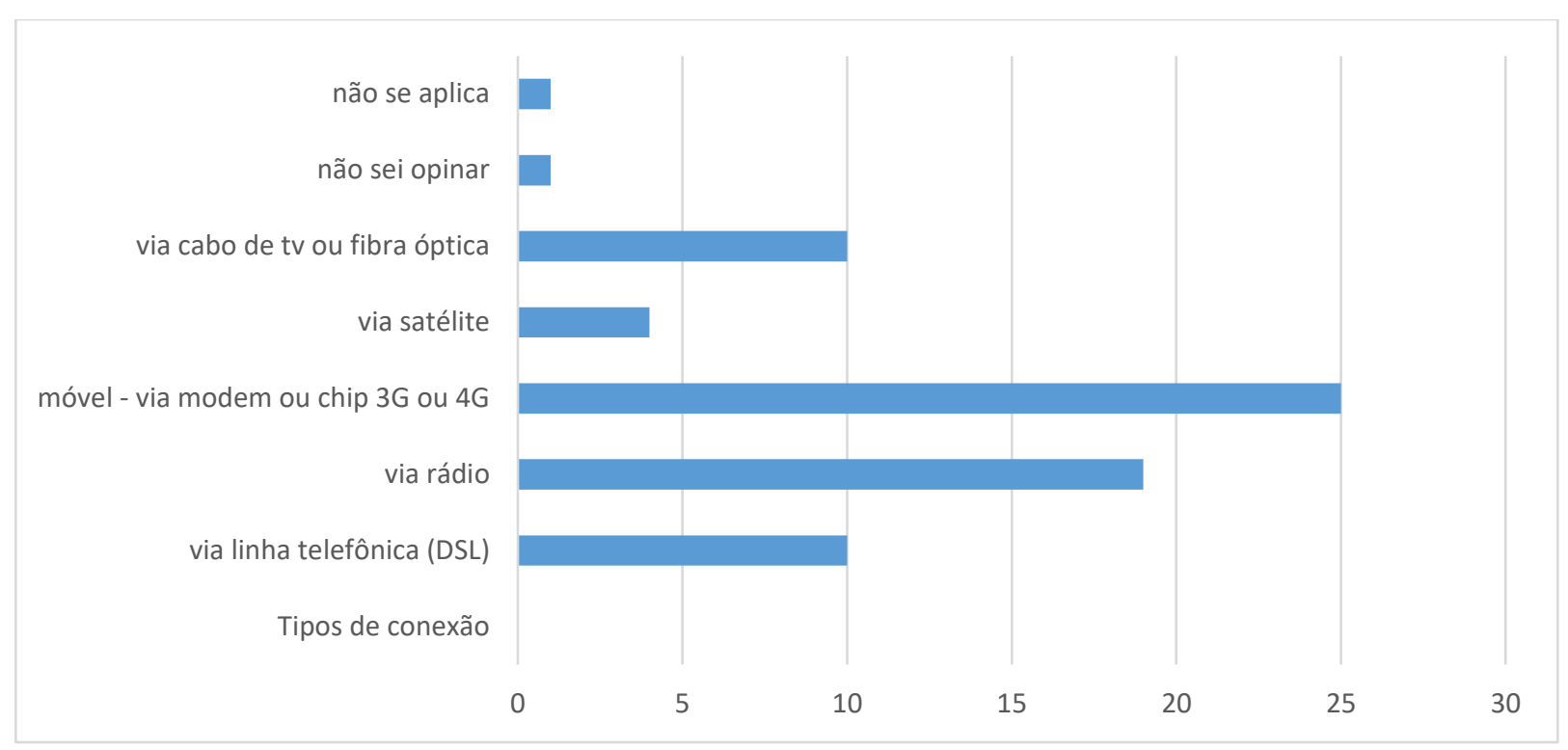

Fonte: Elaborado pelo autor.

Segundo o CANALTECH (2020), grande parte das operações que são feitas na internet envolvem mais download que upload. É o caso de uma pesquisa no Google: digita-se o que se quer encontrar na busca (upload) e o Google retorna com os resultados (download). Essa operacionalidade exige uma banda muito maior para processar os dados, e o tipo de conexão pode ter influência no resultado de uma simples busca por informação na rede de computadores.

Neste sentido, a pesquisa apontou que os empreendimentos rurais possuem diversos tipos de conexões e respectivas velocidades de download. Verificam-se conexões via rádio, com velocidade abaixo de $1 \mathrm{Mbps}$; conexões via cabo de tv ou fibra óptica, móvel $3 \mathrm{G}$ ou $4 \mathrm{G}$ e rádio com velocidade acima de $10 \mathrm{Mbps}$ e uma concentração pulverizada de velocidades entre 2Mbps à 10Mbps (Figura 47). 
Figura 47 - Tipos de conexões à internet e as velocidades de download das conexões dos empreendimentos rurais

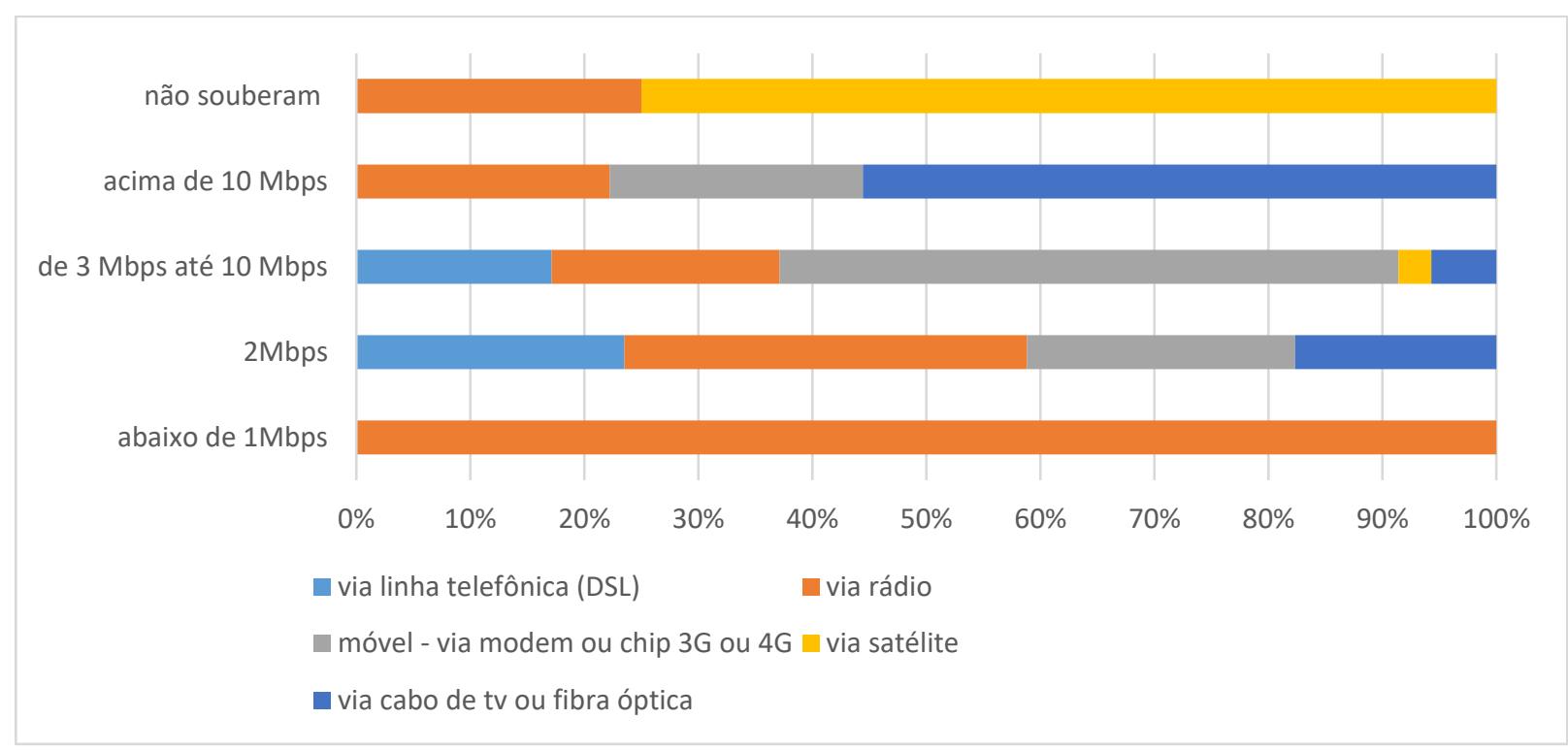

Fonte: Elaborado pelo autor.

A pesquisa também evidenciou que para acessar a rede de computadores, os gestores dos empreendimentos rurais utilizam diversos recursos tecnológicos, conhecidos como hardware, que podem ser entendidos como um conjunto comum de tecnologias usados em computadores que variam de eletrodomésticos inteligentes a telefones celulares e os maiores supercomputadores, podem ter diferentes meios ou finalidades de uso (PATTERSON; HENNESSY, 2017).

Assim, esses diversos equipamentos físicos permitem ao usuário acessar o sistema global de rede de computadores que é interligado (internet) e se comunicar. Para isso, $46 \%$ dos entrevistados utilizam celular para acessar à internet, $31 \%$ notebook, $20 \%$ computador de mesa e $3 \%$ outro equipamento (Figura 48 ). 
Figura 48 - Recursos tecnológicos (hardware) utilizados para acesso à internet nos empreendimentos rurais

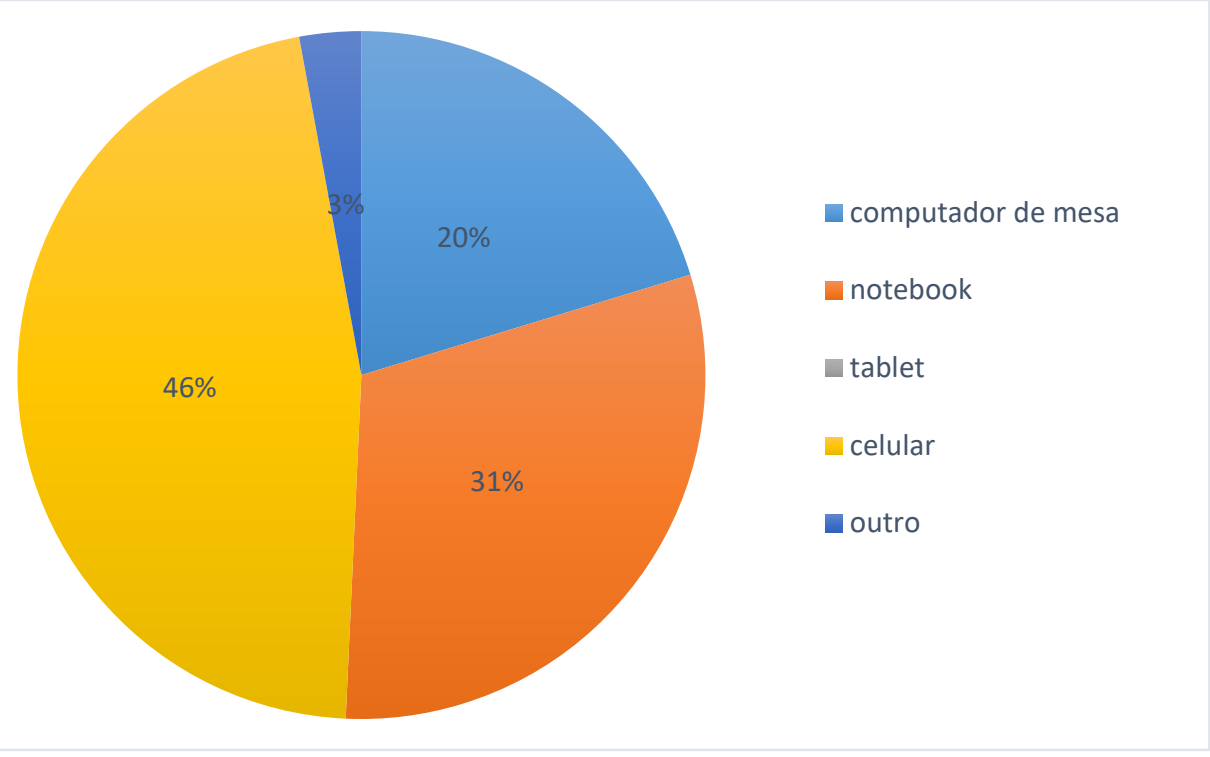

Fonte: Elaborado pelo autor.

Segundo levantamento realizado por CETIC (2018), o nível de escolaridade é um importante indicador de adoção da internet. Uma pessoa com Ensino Superior completo é ao menos duas vezes mais propensa a acessar a Internet do que uma pessoa com Ensino Fundamental incompleto.

Não obstante, a pesquisa junto aos gestores dos empreendimentos rurais apontou que o nível de escolaridade caminha nesta direção. Verifica-se uma baixa aderência ao uso dos recursos tecnológicos (hardware) por quem faz a gestão com nível de formação antigo primário (elementar) e regular do ensino fundamental ou $1^{\circ}$ grau.

Por outro lado, níveis superiores de graduação, mestrado ou doutorado e até mesmo os de regular do ensino médio ou $2^{\circ}$ grau possuem mais aderência ao uso destas tecnologias, com destaque para celular, notebook e computador de mesa (Figura 49). 
Figura 49 - Percentual dos recursos tecnológicos (hardware) utilizados para acessar à internet por nível de escolaridade de quem faz a gestão no empreendimento rural

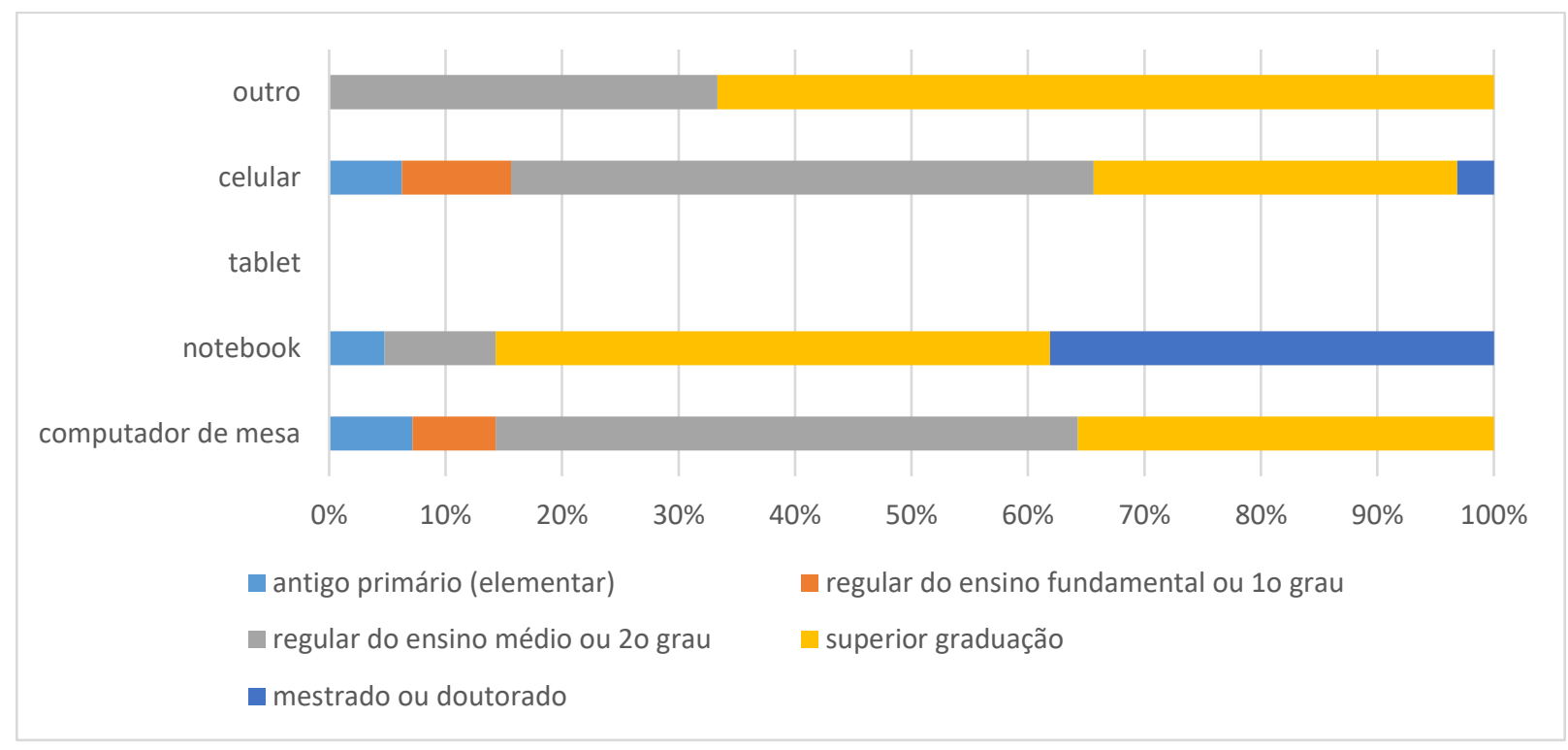

Fonte: Elaborado pelo autor.

5.12 Percepção dos gestores quanto ao conhecimento do sistema (Nav Agro Brasil) a ser proposto como ferramenta de gestão para controle e organização das informações financeiras nos empreendimentos rurais

Para analisar a aderência e identificar se há potencial do uso de ferramentas remotas de gestão para controle e auxílio às tomadas de decisão na área financeira/contábil em empreendimentos rurais, vis-à-vis o acesso à rede de computadores, foram propostas duas questões finais aos entrevistados, com vistas ao conhecimento e o interesse em receber informações detalhadas da ferramenta a ser proposta.

Todos os participantes desconhecem e $91 \%$ tem interesse em receber informações detalhadas sobre a ferramenta, demonstrando que há potencial para o uso de ferramentas remotas (Figuras 50 e 51). 
Figura 50 - Percentual de conhecimento do sistema Nav Agro Brasil por quem faz a gestão nos empreendimentos rurais

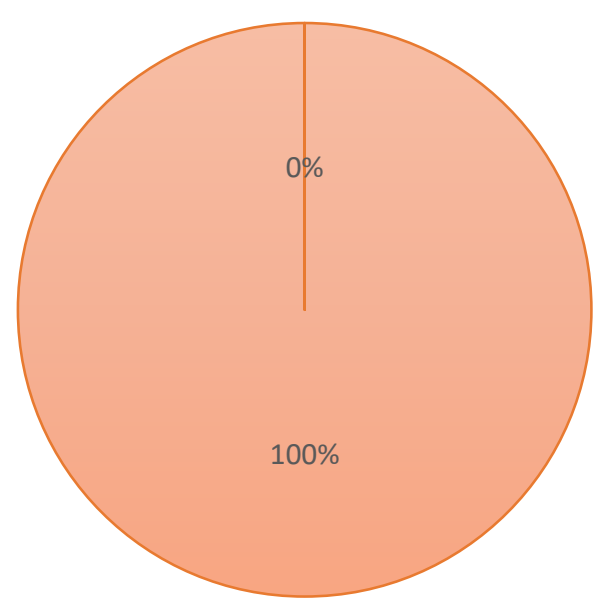

Fonte: Elaborado pelo autor.

Figura 51 - Percentual de interesse em receber informações detalhadas sobre o sistema Nav Agro Brasil por quem faz a gestão nos empreendimentos rurais

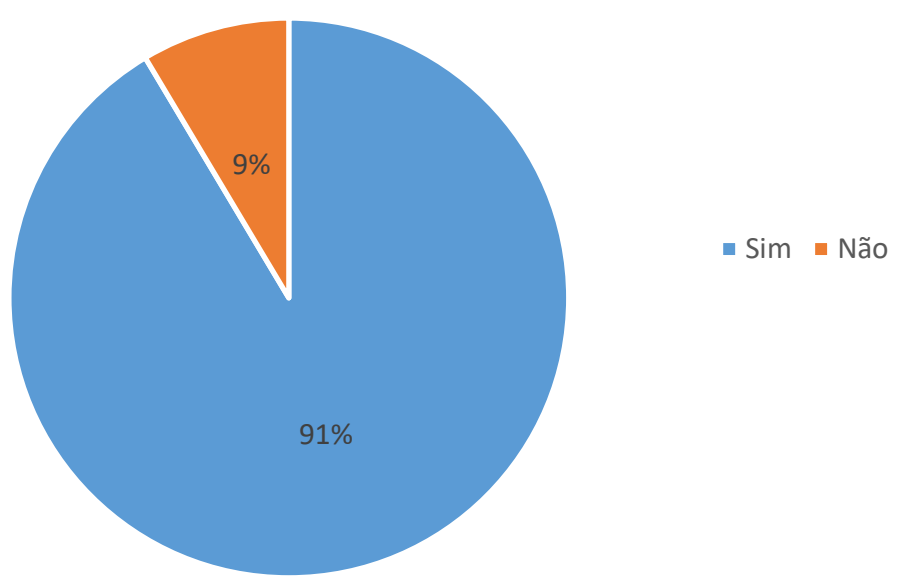

Fonte: Elaborado pelo autor. 


\subsection{Aplicação da análise multivariada de correspondência simples}

\subsubsection{Conjunto de variáveis categóricas de análise por correspondência:} recursos tecnológicos e tipos de controles

Do conjunto de 70 empreendimentos rurais, o teste qui-quadrado para independência foi aplicado numa amostra de 60 empreendimentos, descartando-se 10 empreendimentos que não possuíam controle e apontou dependência (valor-p $=0,017$ ) entre as variáveis para recursos tecnológicos e tipos de controle.

Verificou-se que há preponderância por quem usa celular à prática de controles de formas manuais, através de cadernos de anotações ou caderneta. Por outro lado, o uso de notebook apresentou relação mais próxima aos tipos de controle através de sistema computacional, fichas eletrônicas ou planilhas de Excel (Figura 52).

Figura 52 - Visualização da relação de dependência entre as variáveis: recursos tecnológicos e tipos de controle através dos dados gerados pela análise por correspondência simples.

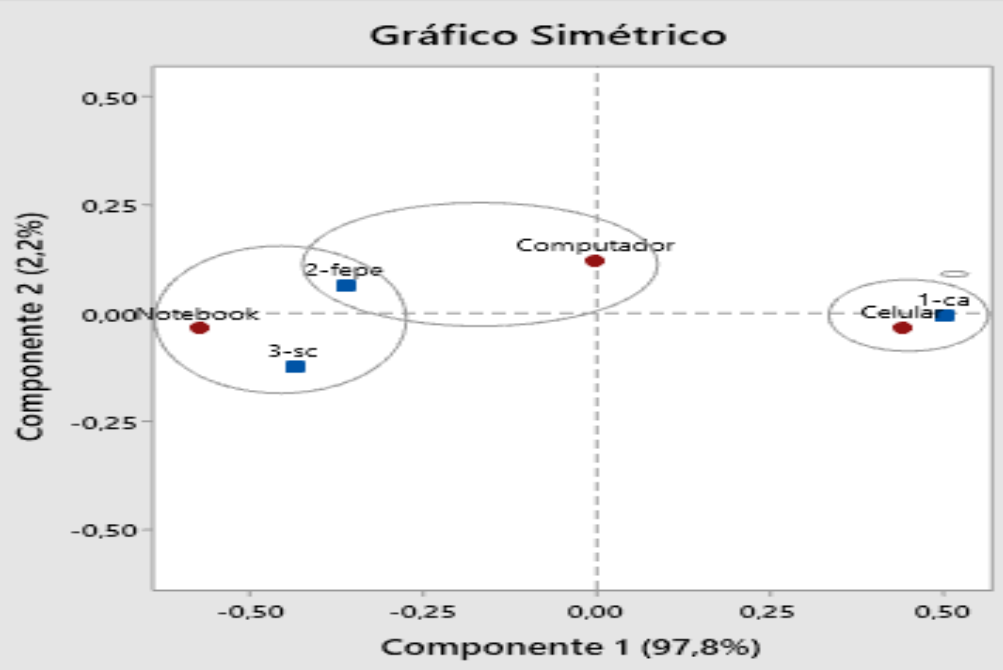

Sigla - categoria da variável

1-ca: caderno de anotações ou caderneta 2-fepe: ficha eletrônica ou planilha de excel 3-sc: sistema computacional

Fonte: Elaborado pelo autor. 
O uso de caderno de anotações ou caderneta é forma de controle financeiro identificado em 26 empreendimentos rurais, com maior aderência para que possuem celular como recurso tecnológico. Por outro lado, 34 empreendimentos rurais possuem algum tipo de controle eletrônico, através do uso de recursos tecnológicos como celular, computador ou notebook, com maior concentração de planilhas eletrônicas ou Excel (Figura 53).

Figura 53 - Uso de tecnologias para controle financeiro em empreendimentos rurais.

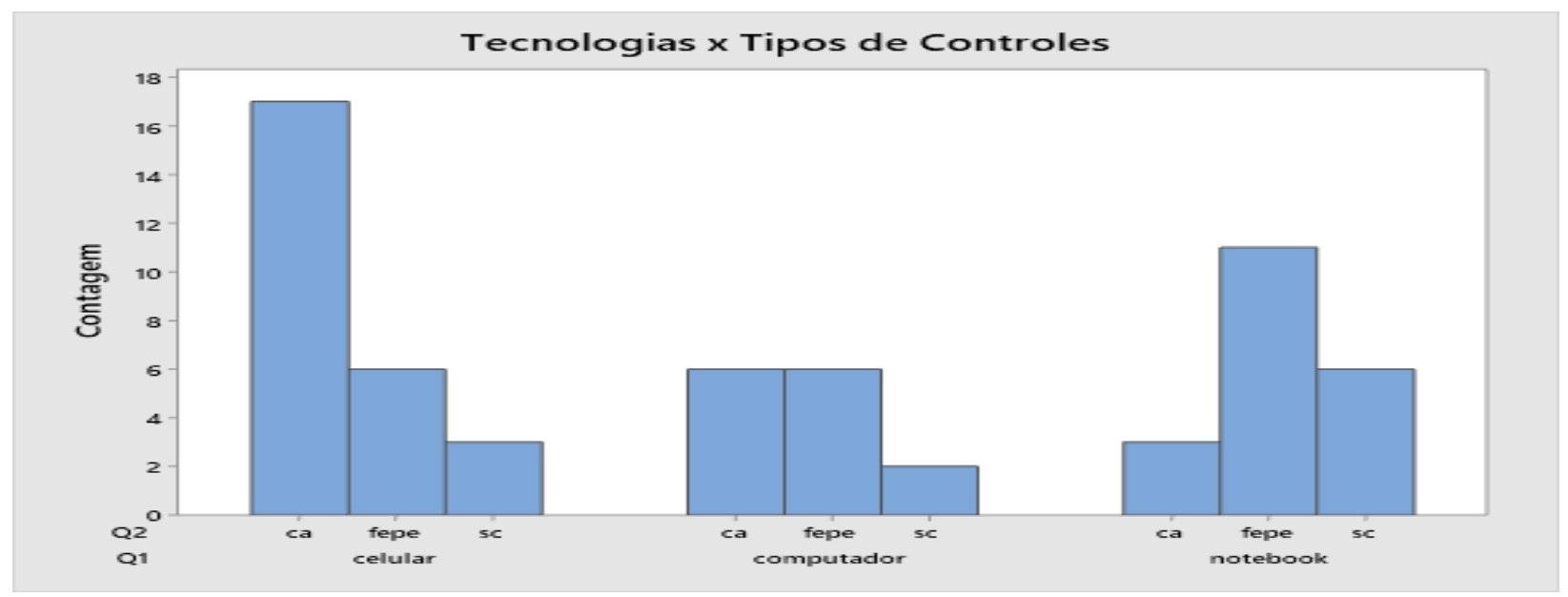

Sigla - categoria da variável

1-ca: caderno de anotações ou caderneta; 2-fepe: ficha eletrônica ou planilha de excel; 3-sc: sistema computacional

Fonte: Elaborado pelo autor.

5.13.2. Conjunto de variáveis categóricas de análise por correspondência: recursos tecnológicos e nível de escolaridade

Do conjunto de 70 empreendimentos rurais, o teste qui-quadrado foi aplicado numa amostra de 67 empreendimentos, descartando-se 3 empreendimentos que não souberam responder e apontou dependência (valor-p $=0,001$ ) entre recursos tecnológicos e nível de escolaridade. 
Os dados apontaram que as tecnologias como notebook apresentaram maior proximidade com pessoas com pós graduação por quem faz a gestão nos empreendimentos rurais. Por outro lado, nível de escolaridade fundamental ou médio apresentou mais aderência ao uso de celular ou computador (Figura 54).

Figura 54 - Visualização da relação de dependência entre as variáveis: recursos tecnológicos e nível de escolaridade através dos dados gerados pela análise por correspondência simples.

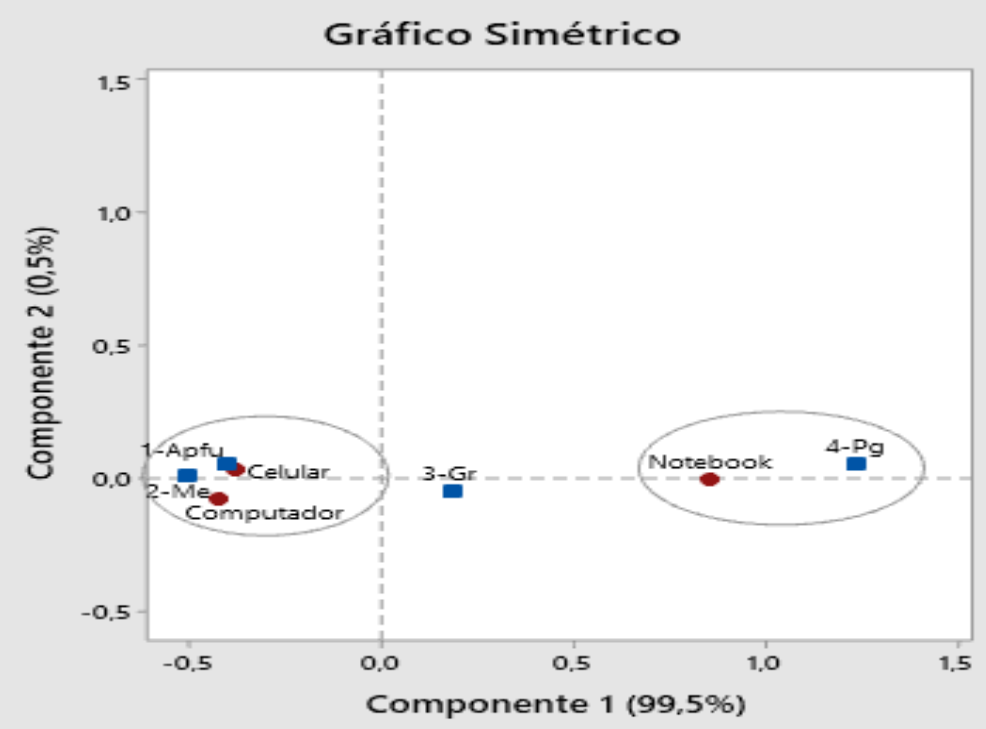

Sigla - categoria da variável

1-Apfu: antigo primário ou regular do ensino fundamental

2-Me: regular do ensino médio

3-Gr: superior graduação

4-Pg: mestrado ou doutorado

Quem faz a gestão nos empreendimentos rurais com níveis de escolaridade de ensino fundamental, médio e superior graduação, apresentaram pré-disposição ao uso dos recursos tecnológicos como o celular e o computador. Por outro lado, níveis de escolaridade superior, graduação, mestrado ou doutorado, apresentaram maior relação às práticas de uso de notebook como recurso tecnológico (Figura 55). 
Figura 55 - Uso de tecnologias para controle financeiro e o nível de escolaridade de quem faz a gestão

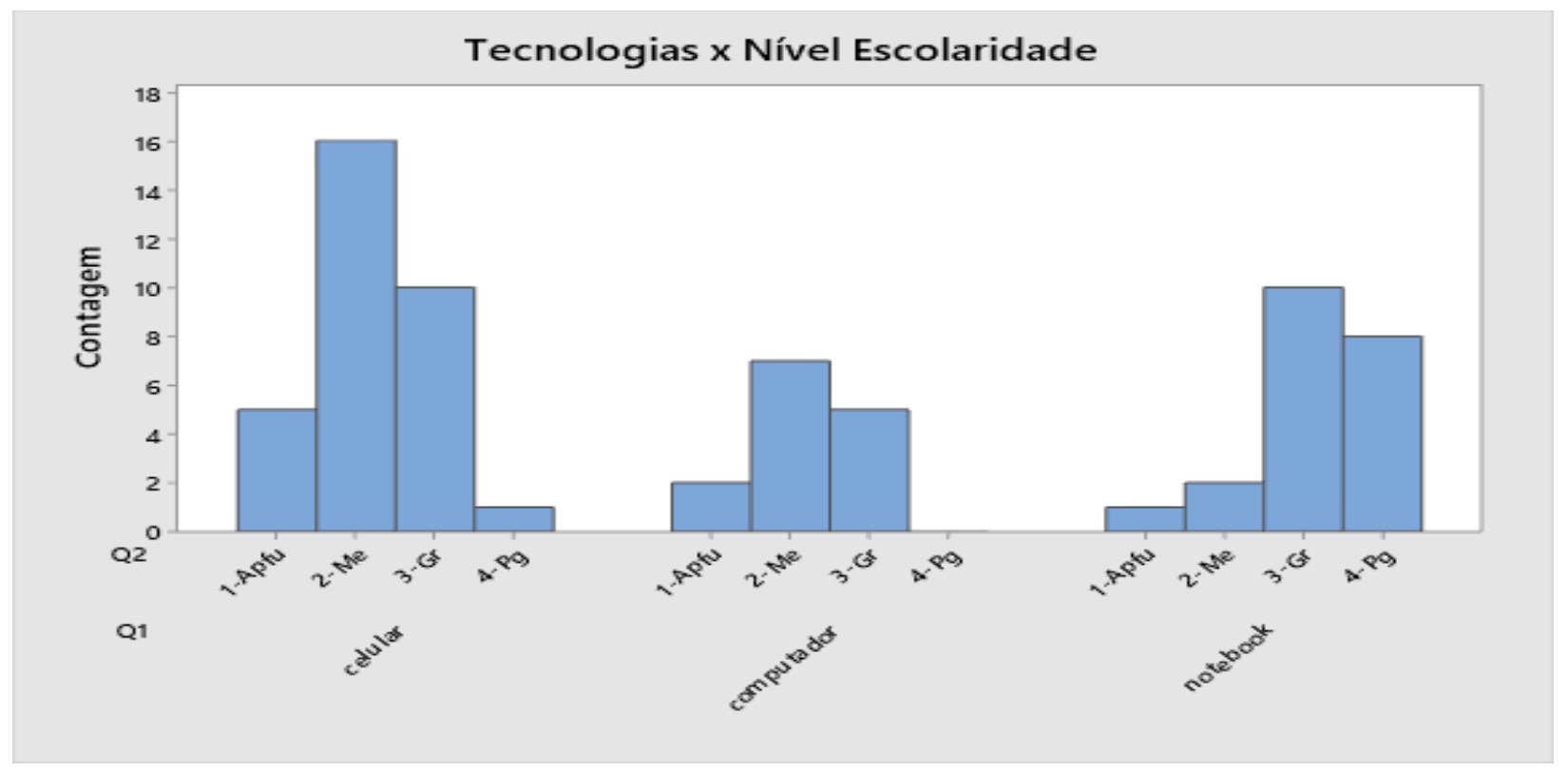

Sigla - categoria da variável

1-Apfu: antigo primário ou regular do ensino fundamental

2-Me: regular do ensino médio

3-Gr: superior graduação

4-Pg: mestrado ou doutorado

Fonte: Elaborado pelo autor.

5.13.3. Conjunto de variáveis categóricas de análise por correspondência: tipos de controles e nível de escolaridade

Do conjunto de 70 empreendimentos rurais, o teste qui-quadrado foi aplicado em uma amostra de 62 empreendimentos, descartando-se 7 empreendimentos que não souberam responder ou não possuem controle e indicou forte dependência (valor-p < 0,001 ) entre tipos de controles e nível de escolaridade.

Os dados apontaram que o uso por controles manuais (caderno de anotações ou cadernetas) tem forte relação com o nível de escolaridade do ensino básico ou fundamental. No ensino superior, graduação e pós-graduação, possuem mais aderência 
ao uso de recursos tecnológicos para fins de controle, como fichas eletrônicas, planilhas de Excel ou sistema computacional (Figura 56).

Figura 56 - Visualização da relação de dependência entre as variáveis: tipos de controles e nível de escolaridade através dos dados gerados pela análise por correspondência simples.

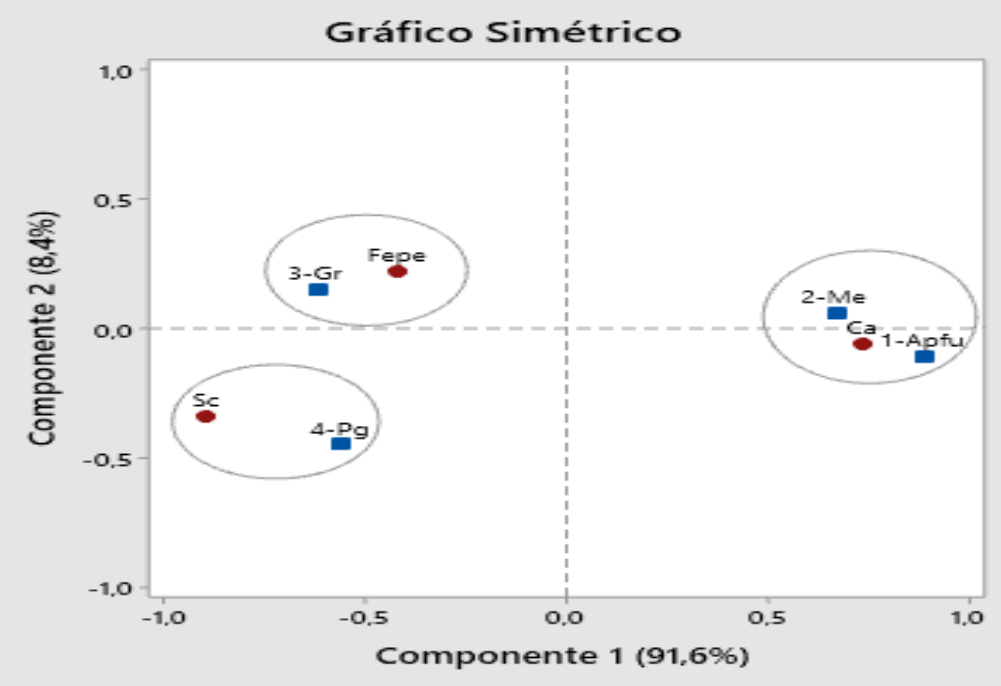

Sigla - categoria da variável

Sigla - categoria da variável

1-Apfu: antigo primário ou regular do ensino fundamental

Ca: caderno de anotações ou

2-Me: regular do ensino médio caderneta

3-Gr: superior graduação

Fepe: ficha eletrônica ou planilha

4-Pg: mestrado ou doutorado de excel

Fonte: Elaborado pelo autor.

Sc: sistema computacional

O uso de papel como único meio de controle financeiro nos empreendimentos rurais, ainda é recorrente nos dias atuais. Os dados apontaram que 27 empreendimentos rurais apresentam esse tipo de prática, com maior ênfase aos gestores que possuem nível de escolaridade básica ou fundamental. Os tipos de controle através de fichas eletrônicas, planilhas de Excel e sistema computacional tem forte aderência por gestor com nível superior de graduação ou mestrado e doutorado (Figura 57). 
Figura 57 - Uso de controles financeiro e o nível de escolaridade de quem faz a gestão.

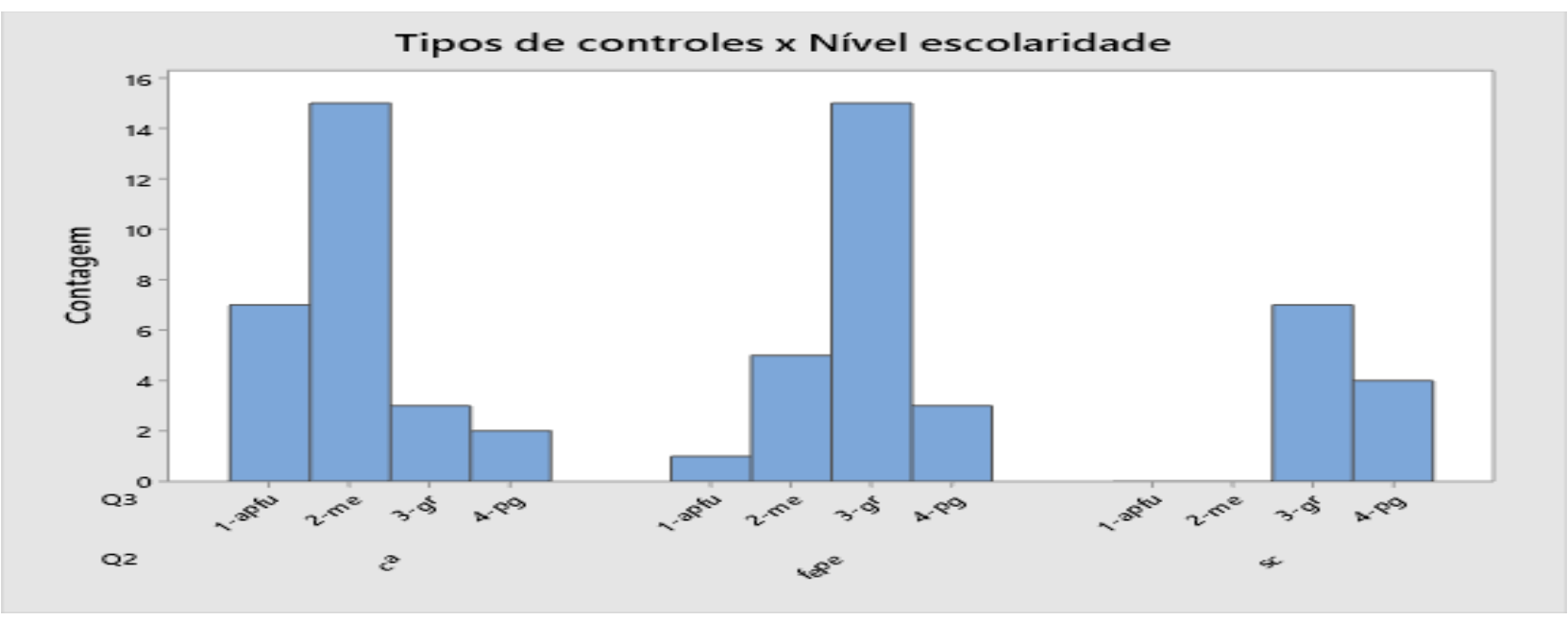

Sigla - categoria da variável

1-Apfu: antigo primário ou regular do ensino fundamental

2-Me: regular do ensino médio

3-Gr: superior graduação

4-Pg: mestrado ou doutorado

Fonte: Elaborado pelo autor.
Sigla - categoria da variável

Ca: caderno de anotações ou caderneta

Fepe: ficha eletrônica ou planilha de excel

Sc: sistema computacional

\subsubsection{Conjunto de variáveis categóricas de análise por correspondência:} índices de gestão e tipos de controles

Este conjunto de variáveis teve por objetivo identificar quais os índices utilizados por quem faz a gestão na propriedade e qual a relação com os controles praticados. Os índices de gestão foram categorizados em técnicos, financeiros, mercado e empírico. Do contingente da amostra de 70 empreendimentos rurais, 58 apresentaram algum tipo de uso de índice de gestão sendo que os demais não utilizam. O teste qui-quadrado indicou uma dependência (valor-p $=0,021$ ) entre os índices de gestão e os tipos de controle (Figura 58).

De um lado, ficaram os empreendimentos rurais que se utilizam do tipo de controle $\mathrm{Ca}$ (caderno de anotações ou cadernetas) e que utilizam índices categorizados como Em (empíricos), ou seja, não há nenhuma consideração técnica, científica ou de outra ordem 
que justifique como informação para auxílio à tomada decisória, perfazendo em sua totalidade como variáveis: intuição, "sexto sentido", experiência pessoal ou achismo.

De outro lado, ficaram aqueles que se utilizam de tecnologias como forma de controle nas atividades dos empreendimentos rurais apresentação o uso de índices de variável de mercado (dólar, arroba do boi gordo, bolsa de valores, entre outros); índices financeiros (fluxo de caixa, grau de endividamento, liquidez, lucratividade, entre outros); índices técnicos de cultivo vegetal ou manejo animal (manejo animal versus desempenho animal, custo por kg ou outra unidade de medida, consumo por carcaça, entre outros).

Figura 58 - Visualização da relação de dependência entre as variáveis: tipos de controles e nível de escolaridade através dos dados gerados pela análise por correspondência simples.

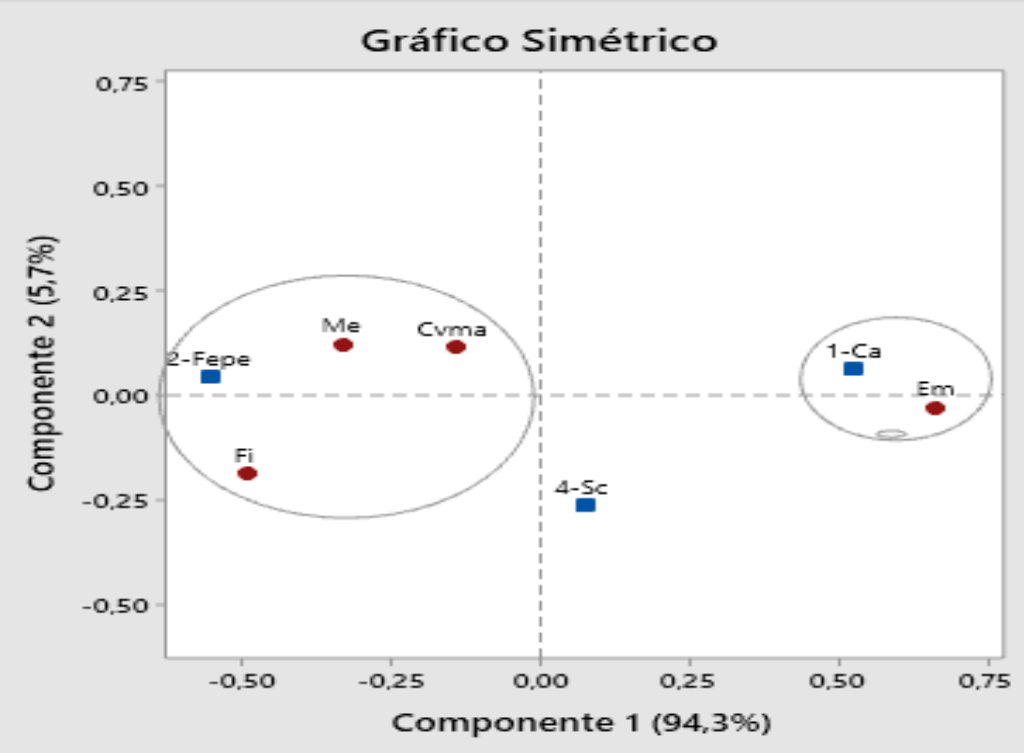

Sigla - categoria da variável

1-Ca: caderno de anotações ou

2-Fepe: ficha eletrônica ou planilha de excel

4-Sc: sistema computacional

Fonte: Elaborado pelo autor.
Sigla - categoria da variável

Em: empírico

Cvma: cultivo vegetal e manejo animal

Fi: financeiro

Me: mercado

Os dados apontaram uma forte indicação de que existe uma relação entre o uso de índices considerados empíricos (intuição, "sexto sentido", experiência pessoal ou 
achismo) por gestores que se utilizam de cadernos de anotação ou cadernetas como forma de controlar as movimentações financeiras nos empreendimentos rurais, em contraponto àqueles que utilizam uma maior predominância do uso de controles financeiros através de meio eletrônico, como fichas eletrônicas, planilhas de Excel ou sistema computacional o uso de indicadores de cultivo vegetal, manejo animal, financeiro e de mercado (Figura 59).

Figura 59 - Uso de índice de gestão e tipos de controles utilizados por quem faz a gestão.

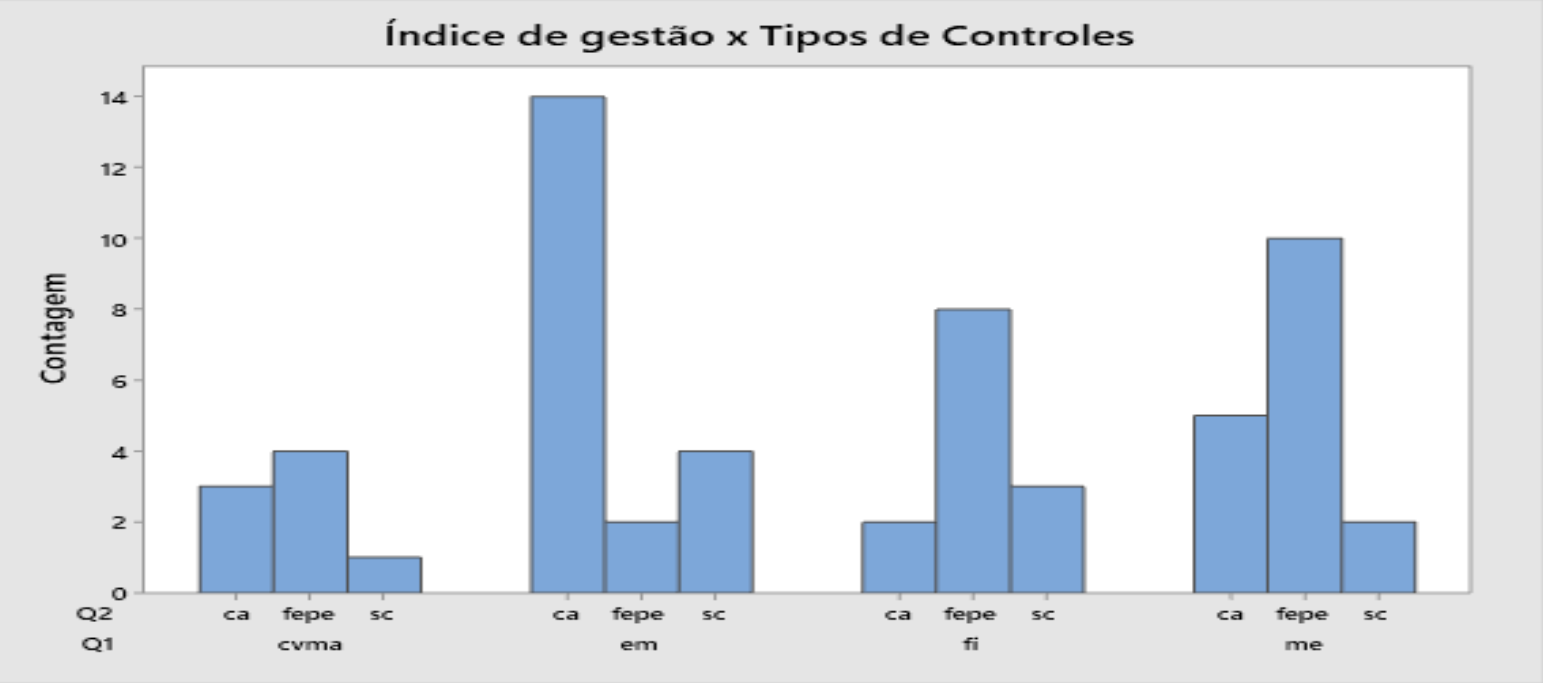

Sigla - categoria da variável

1-Ca: caderno de anotações ou

2-Fepe: ficha eletrônica ou planilha de excel

4-Sc: sistema computacional
Sigla - categoria da variável Em: empírico Cvma: cultivo vegetal e manejo animal Fi: financeiro Me: mercado

Fonte: Elaborado pelo autor.

\subsubsection{Conjunto de variáveis categóricas de análise por correspondência: conexões e velocidades de download}

Este conjunto de variáveis teve por objetivo identificar se há conectividade, banda, velocidade de download nos empreendimentos rurais. Do contingente da amostra, 63 apresentaram conectividade e respectivas velocidades de download. 7 produtores também apontaram possuir conectividade, contudo, não souberam informar a velocidade, 
por esse motivo foram descartados da análise. O teste qui-quadrado apontou uma forte dependência (valor-p $=0,002$ ) entre os tipos de conexão e as velocidades de download.

As variáveis categóricas - velocidades de download foram classificadas como le (lenta) para velocidades abaixo de $2 \mathrm{Mpb}$; ra (rápida) para velocidades entre $3 \mathrm{Mbps}$ e $10 \mathrm{Mbps}$ e su (super) para velocidades acima de 10Mbps. Os meios de tráfego das informações (conexão) foram classificados em tecnologias (rádio, digital subscriber line - dsl, cabo de fibra óptica e banda móvel). Os dados apontaram que os empreendimentos que utilizam a tecnologia rádio utilizam velocidades abaixo de $2 \mathrm{Mpbs}$ (lenta), tecnologias cabo de fibra óptica apresentaram velocidades acima de 10Mpbs (superiores) e conexões através de banda móvel velocidades entre $3 \mathrm{Mbps}$ e $10 \mathrm{Mbps}$ classificadas como rápidas (Figura 59).

Figura 60 - Visualização da relação de dependência entre as variáveis: conexões e velocidades de download através dos dados gerados pela análise por correspondência simples.

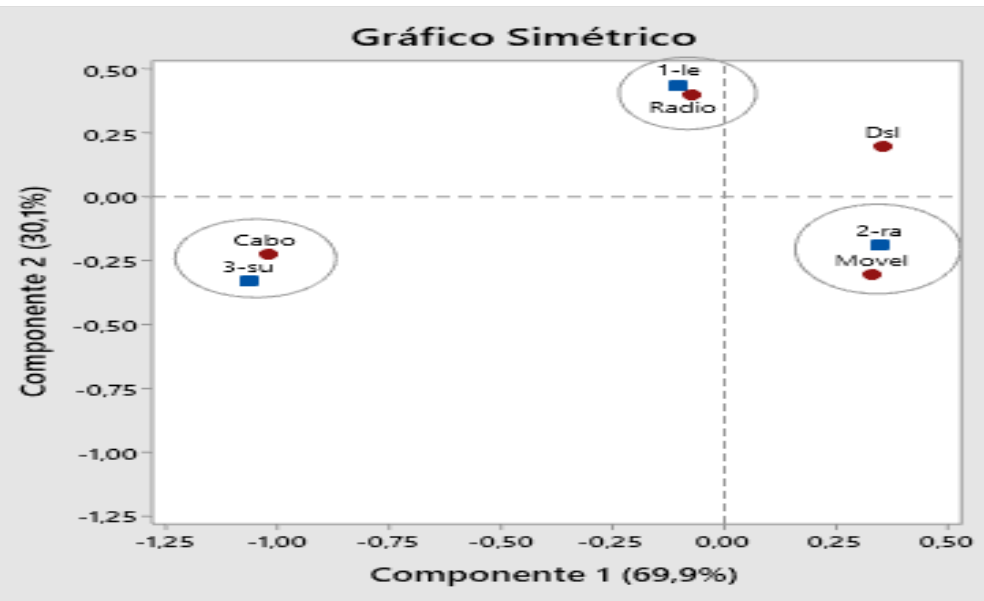

Sigla - categoria da variável

1-le: lenta

2-ra: rápida

3-su: super

Fonte: Elaborado pelo autor.

Sigla - categoria da variável Cabo: fibra óptica Dsl: digital subscriber line Móvel: banda móvel 3G, 4G ou 5G Rádio: transmissão por torre 


\section{CONSIDERAÇÕES FINAIS}

Este estudo objetivou identificar a existência de potencialidade do uso de ferramentas de gestão e auxílio às tomadas de decisão dentro das propriedades rurais vis-à-vis o acesso à rede de computadores no Brasil, evidenciando variáveis que possam ou não contribuir para uma possível demanda por ferramentas computadorizadas.

A metodologia utilizada foi baseada em pesquisa qualitativa e quantitativa (análise de depoimentos) com arrendatários, produtores rurais e gestores de propriedades rurais, através de um questionário com respostas abertas e fechadas (APÊNDICE) aplicado online via Google formulários para potenciais usuários do software a ser proposto e entrevistas com especialistas e formadores de opinião na área de gestão. Foram mensurados os principais indicadores para avaliar os impactos gerados: recursos tecnológicos, tipo de conexão, acesso à internet, percepção de lucro, índices utilizados para gestão, nível de formação, tipos de controles produtivos e financeiros.

O universo de pesquisa considerou 13 Estados Brasileiros, totalizando 70 propriedades rurais. As ferramentas de análise utilizadas neste trabalho foram: estatística descritiva e análise de correspondência simples.

Os resultados apontam, que de um lado, quem faz a gestão nos empreendimentos rurais com níveis de escolaridade de ensino fundamental, médio e superior graduação, apresentaram pré-disposição ao uso dos recursos tecnológicos como celular, computador e notebook, mas que o uso de papel como único meio de controle financeiro ainda é recorrente nos dias atuais principalmente pelos gestores com nível de escolaridade de ensino fundamental e médio.

De outro lado, quem faz a gestão nos empreendimentos rurais com níveis de escolaridade no ensino superior graduação e pós-graduação possuem mais aderência ao uso de recursos tecnológicos para fins de controle, como fichas eletrônicas, planilhas de Excel ou sistema computacional. 
Neste contexto, é importante destacar que os resultados obtidos na pesquisa qualitativa e quantitativa, onde analisou-se a amostra pode não refletir a realidade do País, mas de alguma forma, uma contribuição aos agentes participantes.

Pode ser relevante a sugestão de se repetir a pesquisa, como parte da análise continuada desse estudo, com o aumento do número de respondentes, para que a ampliação da amostra seja, no futuro, mais fidedigna da realidade encontrada, constituindo-se aqui um dos principais aspectos limitantes deste estudo qualitativo.

Sob o panorama geral, apreendido pela metodologia da pesquisa e obtido através da revisão da literatura e com base nos dados primários colhidos pela colaboração dos autores, ressalta-se a relevância e a eficácia da análise de correspondência para legitimar e evidenciar os resultados obtidos qualitativa e quantitativamente.

Ao final, foi identificado forte viés de um olhar para a gestão, com uso de ferramentas computadorizadas como alternativa imprescindível na obtenção de informações rápidas, padronizadas e organizadas, tendo como opção a ferramenta Nav Agro Brasil que será apresentada junto aos respondentes com predisposição às questões 27 e 28 do diagnóstico de demanda com futuros consumidores.

Portanto, confirma-se, assim a hipótese inicial, a qual sustentava o argumento de que "buscou-se detectar o potencial do uso de ferramentas de gestão para controle e auxílio às tomadas de decisão dentro das propriedades rurais vis-à-vis o acesso à rede de computadores no Brasil". Além disso, abriram-se possibilidades futuras de discussões nessa linha de pesquisa ao se considerar: nível de escolaridade, regionalização, tipos de culturas e manejo, tipos de ferramentas de apoio a gestão, tributação, entre outras.

Podem-se citar os seguintes impactos do trabalho, tais como: a) para o Programa de Gestão e Inovação na Industria Animal - GIIA; b) para o mercado consumidor de software; c) para o pesquisador e a organização em que trabalha com apoio aos produtores rurais e para à sociedade no geral. 


\section{REFERÊNCIAS}

AGÊNCIA BRASILEIRA DE DESENVOLVIMENTO INDUSTRIAL (ABDI). O desafio da conectividade no campo. Disponível em: <https://www.abdi.com.br/postagem/odesafio-da-conectividade-no-campo\#>. Acesso em: 10 abr. 2019.

AGÊNCIA NACIONAL DE TELECOMUNICAÇÕES (ANATEL). Decreto n.9.619, de 20 de Dezembro de 2018. Estabelece metas de acessos individuais nas áreas rurais. Seção III, art.80. parágro 10.1 Disponível <http://www.anatel.gov.br/legislacao/decretos/1243-decreto-9619>. Acesso em: 20 abr.2019.

AGUIAR, A.P.A.; RESENDE, J.R. Pecuária de Corte. Custos de Produção e Análise Econômica. Viçosa. Minas Gerais. Aprenda Fácil. 2013.

AFFONSO, E.P.; VITOR, C.A.P.; SANT'ANA, R.C.G.; ANDRADE, A.S. Contribuição das TIC para recuperação de dados sobre produtores da agricultura familiar. In: Colloquium Humanarum, Presidente Prudente, v. 12, n. 1, p.81-88, jan/mar 2015. DOI: 10.5747/ch.2015.v12.n1.h189.

ALONSO, A.; MIRANDA, D.S. Métodos de pesquisa em Ciências Sociais: bloco quantitativo. Sec São Paulo/CEBRAP. São Paulo, 2016.

ARAÚJO, M.J. Fundamentos de agronegócios. 4. ed. São Paulo: Atlas, 2013.

ARTUZO, F.D.; JANDREY, W.F.; KALSING, J.; SILVA, P.X.; SILVA, L.X. Utilização da tecnologia de informação em propriedades rurais: um estudo de caso no município de Getúlio Vargas (RS). Revista em Agronegócio e Meio Ambiente, Maringá (PR). Disponível em: http://dx.doi.org/10.17765/2176-9168.2016v9n2p305-322. Acesso em: 20 fev. 2019.

ASSOCIAÇÃO BRASILEIRA DAS EMPRESAS DE SOFTWARE (ABES). Mercado brasileiro de software: panorama e tendências. $1^{\circ}$ ed. São Paulo, 2019. 
BANCO DO BRASIL (BB). PRONAF custeio. Disponível em: $<$ https://www.bb.com.br/pbb/pagina-inicial/agronegocios/agronegocio---produtos-eservicos/credito/credito-para-custeio/PRONAF-custeio\#/>. Acesso em: 20 mar. 2020.

BANCO NACIONAL DE DESENVOLVIMENTO ECONÔMICO E SOCIAL (BNDES). PRONAF - Programa Nacional de Fortalecimento da Agricultura Familiar. Disponível em: <https://www.bndes.gov.br/wps/portal/site/home/financiamento/produto/PRONAF>. Acesso em: 20 mar. 2020.

BENZÉCRI, J.P. Correspondence analysis handbook. New York: Marcell Dekker, 1992.

BHANGE, M.; HINGOLIWALA, H.A. Smart Farming: Pomegranate Disease Detection Using Image Processing. Second International Symposium on Computer Vision and the Internet (VisionNet'15). Procedia Computer Science, 58, p. $280-288,2015$. DOI: 10.1016/j.procs.2015.08.022.

BERNARDES, J.C.; VIEIRA, S.C.; BONFIM, E.B.; SANT'ANA, R.C.G. O uso das tecnologias de informação e comunicação na agricultura familiar: um caminho para sustentabilidade. In: XI Fórum Ambiental da Alta Paulista, v. 11, n. 9, 2015, pp. 113127.

BORGES, V. de O. A tecnologia de informação e comunicação como ferramenta de apoio ao produtor rural no processo de gestão. Dissertação de Mestrado. Faculdades Integradas do Sudoeste Mineiro - FESP. Universidade do Estado de Minas Gerais. Passos, MG: 2015.

BREITENBACH, R. Gestão rural no contexto do agronegócio: desafios e limitações. Desafio online. Campo Grande, v.2, n.2, mai./ago. 2014.

CALLADO, A.A.C.; CALLADO, A.L.C. Custos no processo de tomada de decisão em empresas rurais. IX Congresso Brasileiro de Custos - São Paulo. São Paulo. ISSN: 2358-856X. 
CANALTECH.

Releases.

Disponível

em:

$<$ https://

https://canaltech.com.br/internet/diferencas-entre-velocidade-de-upload-e-download/>. Acesso em: 31 mar. 2020.

CENTRO DE ESTUdOS AVANÇADOS EM ECONOMIA APLICADA. Cepea. ESALQ/USP. Cadernos especiais, 2019. Disponível em: < https://www.cepea.esalq.usp.br/br/pib-do-agronegocio-brasileiro.aspx>. Acesso em: 10 mar. 2019.

CENTRO DE PESQUISA E DESENVOLVIMENTO EM TELECOMUNICAÇÕES (CPqD). Releases. Disponível em: <https://www.cpqd.com.br/agronegocio-inteligente/>. Acesso em: 08 abr. 2019.

CENTRO DE PESQUISA INTERDICIPLINAR EM DIREITO E TECNOLOGIA (INTERNETLAB).

Releases.

Disponível

em:

$<$ https://www.internetlab.org.br/pt/especial/5-anos-depois-um-balanco-das-politicaspublicas-de-internet-no-brasil/>. Acesso em: 30 mar. 2020.

CENTRO REGIONAL DE ESTUDOS PARA O DESENVOLVIMENTO DA SOCIEDADE DA INFORMAÇÃO (CETIC). Releases. Pesquisa sobre o uso das tecnologias de informação e comunicação nos domicílios brasileiros - TIC Domicílios 2018, São Paulo, ISBN 978-85-5559-087-0, 2018.

CENTRO REGIONAL DE ESTUDOS PARA O DESENVOLVIMENTO DA SOCIEDADE DA INFORMAÇÃO (CETIC). Banda larga no Brasil: um estudo sobre a evolução do acesso e da qualidade das conexões à internet. Comitê gestor da internet no Brasil CGI.br, São Paulo, SP, 2018. Disponível em: < http:// https://cetic.br/media/docs/publicacoes/1/Estudo\%20Banda\%20Larga\%20no\%20Brasil. pdf>. Acesso em: 18 mar. 2020.

DUARTE, R. Entrevistas em pesquisas qualitativas. Educar em revista, v. 20, n. 24, p. 213-225, 2004. 
EMPRESA BRASILEIRA DE PESQUISA AGROPECUÁRIA (EMBRAPA). Programa Embrapa Labex. Disponível em: <https://www.embrapa.br/programa-embrapa-labex> Acesso em: 12 abr. 2019.

ESTADOS UNIDOS (USAD). Department of Agriculture. Farm computer usage and ownership. Washington, D. C., 2013. 30 p. Disponível em: <http://usda.mannlib.cornell.edu/usda/current/FarmComp/FarmComp-08-20-2013.pdf > Acesso em: 18 abr. 2019.

FAR, S.T.; MOGHADDAM, K.R. Impacts of the precision agricultural technologies in Iran: An analysis experts' perception \& their determinants. Information Processing in Agriculture 5, Issue 1. p.173-184, 2018. Disponível em: https://doi.org/10.1016/j.inpa.2017.09.001

FERNANDES, R. A.; SEVERO, J. A.; ANTUNES, L.W. A utilização de tecnologia e inovação na gestão de propriedades rurais e sua relação com a produtividade e rentabilidade. Unoesc \& Ciência - ACSA, Joaçaba, v. 9, n. 2, p. 145-153, jul/dez 2018.

FERRAZ, C. O.; PINTO, W. F. Tecnologia da Informação para a Agropecuária: Utilização de Ferramentas da Tecnologia da Informação no Apoio a Tomada de Decisões em Pequenas Propriedades. RECoDAF - Revista Eletrônica Competências Digitais para Agricultura Familiar, Tupã, v. 3, n. 1, p. 38-49, jan./jun. 2017. ISSN: 2448-0452.

FERREIRA, J.B.; SILVA, J.F.; GIOVANNINI, C.J.; RAMOS, F.L. Fatores que afetam a adoção da internet móvel. PRETEXTO - Revista Eletrônica Universidade FUMEC, Belo Horizonte, v. 17, n. 4, p. 47-64, out./dez. 2016. ISSN: 1984-69.

FONSECA, E.; CALDEIRA, E.; OLIVERIA, L.; PEREIRA, A.C.M.; VILELA, P.S. Agro 4.0 uma ferramenta web para gestão e análise da sustentabilidade em agroecossistemas. In: XVI Workshop de Ferramentas e Aplicações (WFA 2017), Gramado, Brasil. Anais do XXIII Simpósio Brasileiro de Sistemas Multimídia e Web: Workshops e Pôsteres. Porto Alegre: Sociedade Brasileira de Computação, 2017. 
FONTOURA, F.B.B. da; DEPONTI, C.M. Desenvolvimento rural: a importância das TICs e dos controles econômicos e financeiros na visão dos agricultores familiares do Vale do Caí-RS. RBPD. Revista brasileira de planejamento e desenvolvimento, vol.7, n.1, p.85-103, Curitiba (SP), jan./abr. 2018.

GELB, E. The EFITA Bonn - Turino Conferences (1999-2013): ICT adoption questionnaire update. [2013]. Disponível em: <http://www.informatiqueagricole.org/gazette/Efita_Documents/ICT\%201999\%20-\%202013\%20

Questionnaire\%20summary\%20with\%200ssiach\%20-\%20updated\%20(3).pdf>. Acesso em: 17 mar. 2019.

GELB, E. The EFITA ICT adoption questionnaire: 1999-2011 priority indicators for the future. [2012]. 11 p. Disponível em: <http://departments.agri.huji.ac.il/economics/gelbefita-2012.pdf $>$. Acesso em: 08 abr. 2019.

GIL, A. C. Estudo de caso. Atlas, 2009.

GODOY, A. S. Pesquisa qualitativa: tipos fundamentais. Revista de Administração de empresas, v. 35, n. 3, p. 20-29, 1995.

HAGUETTE, T. M. F. Fundamentos teóricos de algumas metodologias qualitativas na sociologia. Haguette TMF. Metodologia qualitativa na sociologia. 1a. ed. Petrópolis: Vozes, p. 24-47, 2001.

HAIR, Jr. J. F.; BABIN, B.; MONEY, A. H.; SAMOUEL, P. Fundamentos de métodos de pesquisa em administração. Bookman Companhia Ed. 2005.

HAIR, Jr. J. F.; BABIN, B.; MONEY, A. H.; SAMOUEL, P. Análise multivariada de dados. Bookman Companhia Ed., 6ª ed., 2009.

HORIGOSHI, F.M. Uso de sensor efeito Hall para medição de vazão de fluidos no processo de produção de palatabilizantes a base de proteína animal em escala piloto. Dissertação de Mestrado. Programa de gestão e inovação na indústria animal - GIIA. Faculdade de zootecnia e engenharia de alimentos - FZEA. Universidade de São Paulo. Pirassununga, SP: 2016. 
IBGE. Censo agropecuário 2017. Rio de Janeiro, 2019. Disponível em: < https://sidra.ibge.gov.br/acervo\#/S/Q >. Acesso em: 17 mar. 2019.

IBGE. Censo agro 2017. Rio de Janeiro, 2019. Disponível em: <https://censoagro2017.ibge.gov.br/templates/censo_agro/resultadosagro/index.html>. Acesso em: 23 mar. 2020.

IBGE. Censo agro 2017. Sistema de recuperação automática (SIDRA) Rio de Janeiro, 2019. Disponível em: <https://sidra.ibge.gov.br/pesquisa/censo-agropecuario/censoagropecuario-2017>. Acesso em: 23 mar. 2020.

INSTITUTO NACIONAL DE COLONIZAÇÃO E REFORMA AGRÁRIA (INCRA). Dados sobre estrutura fundiária do Brasil - julho de 2018. Disponível em: < http://portal.incra.gov.br/sites/default/files/uploads/estrutura-fundiaria/regularizacaofundiaria/estatisticas-cadastrais/estrutura_fundiaria_-_brasil-07-2018.pdf>. Acesso em: 20 mar. 2020.

JORNAL O ESTADÃO. Releases. Disponível em: $<$ https://especiais.estadao.com.br/canal-agro/agrotech/o-desafio-da-conectividade-noagro/>. Acesso em: 31 mar. 2020.

KIRSCH, D. B.; LEMES, L. R. Caracterização da estrutura da pesquisa cientifica. 2019. (Folheto Academia da Força Aérea/ Divisão de Ensino, 2019).

LAMPERT, V.N.; AMARAL, É.M.H.; LOPES, P.P.; FRACARI, J.R.; DANTAS, T.F.;OLIVEIRA, M.C.C. Uma ferramenta para gestão de indicadores na produção de bovinos de corte: simplificando a organização de processos. In: X Congresso brasileiro de agroinformática. Anais eletrônicos. out.2015, em parceria com EMBRAPA Pecuária do Sul e o curso de engenharia da computação da Universidade Federal do Pampa (UNIPAMPA)-Campos Bagé.

LEANDRO, T. A oferta de pacotes Triple Play: efeitos da venda conjunta dos serviços de TV por assinatura, banda larga e telefonia fixa no mercado brasileiro. Tese de Doutorado. Departamento de economia da Universidade de Brasília. Brasília, SP: 2017. 
LEMOS, R. dos S. A importância da utilização das ferramentas de gestão para a organização interna das pequenas empresas rurais: um estudo de caso no assentamento Bethinho com produtores de morango. Relatório final de Estágio Supervisionado do curso de bacharel em Gestão de Agronegócio - Faculdade UnB Planaltina - Universidade de Brasília, Distrito Federal, 2015.

LIMA, M.F.U.M. de. Políticas públicas de acesso à internet: análise do projeto Banda Larga Popular. Dissertação de Mestrado. Universidade de Brasília, Brasília, 146 f., il., 2017.

LIZZONI, L.; FEIDEN, AL.; FEIDEN, AR.; Sistemas de Informação como ferramenta de apoio à diversificação rural. RECoDAF - Revista Eletrônica Competências Digitais para Agricultura Familiar. v. 4, n. 1. 2018. ISSN: 2448-0452.

LODI, J.B. A entrevista: teoria e prática. São Paulo: Pioneira. 1991.

LOPES, M.A.; REIS, E.M.B.; DEMEU, F.A.; MESQUITA, A.A.; ROCHA, A.G.F.; BENEDICTO, G.C. Uso de ferramentas de gestão na atividade leiteira: um estudo de caso no sul de Minas Gerais. Revista Científica de Produção Animal. v.18, n.1, p.2644, 2016. Disponível em: http://dx.doi.org/10.5935/2176-4158/rcpa.v18n1p26-44.

MACHADO, J.G.C.F.; NANTES, J.F.D. Adoção da tecnologia da informação em organizações rurais: o caso da pecuária de corte. Gestão e Produção, São Carlos, v. 18, n. 3 , p. 555-570, 2011. jan.2011. Disponível em: https://www.researchgate.net/publication/307672073.

MANZINI, E. J. A entrevista na pesquisa social. Didática, v. 26, p. 149-158, 1990.

MARCONI, M. A.; LAKATOS, E. M. Fundamentos de metodologia científica. 5. ed.São Paulo: Atlas, 2003.

MATSUNAGA, M.; BEMELMANS, P. F.; TOLEDO, P. E. N.; DULLEY, R. D.; OKAWA, H.; PEDROSO, I. A. Metodologia de custo de produção utilizada pelo IEA. Agricultura em São Paulo, São Paulo, v. 23, t. 1, p. 123-139, 1976. 
MENDES, C.I.C.; OLIVEIRA, D.R.M.S.; SANTOS, A.R. (org.). Estudo do Mercado

Brasileiro de Software para o Agronegócio. Embrapa Informática Agropecuária: Campinas, p. 187, 2011.

MINISTÉRIO DA AGRICULTURA, PECUÁRIA E ABASTECIMENTO (MAPA). Plano Agrícola e Pecuário 2018. Disponível em: < http://www.agricultura.gov.br/assuntos/politica-agricola/plano-agricola-epecuario/arquivos-pap/folder-pap-2018-2019 >. Acesso em: 05 abr. 2019.

MINISTÉRIO DA AGRICULTURA, PECUÁRIA E ABASTECIMENTO (MAPA). Projeções do agronegócio Brasil 2017/2018 a 2017/2028. Disponível em: <www.agricultura.gov.br/...agronegocio/.../PROJEÇÕES\%20DO\%20AGRONEGÓCIO\% 2...> Acesso em: 20 abr. 2019.

O'BRIEN. J.A. Sistemas de informação e as decisões gerenciais na era da internet. 3. ed. São Paulo: Saraiva, 2011.

OLIVEIRA, M.E. Desenvolvimento de sistema automatizado de monitoramento de ambientes de produção animal, utilizando uma rede de sensores sem fio. Dissertação de Mestrado. Programa de gestão e inovação na indústria animal - GIIA. Faculdade de zootecnia e engenharia de alimentos - FZEA. Universidade de São Paulo. Pirassununga, SP: 2016.

PADOVEZE, Clóvis Luís. Controladoria estratégica e operacional. 2. ed. São Paulo: Cengage Learning, 2011.

PARANÁ PORTAL. Folhapress. Agropecuária fica estagnada em 2018, 28 Fev. 2019. Disponível em: < https://paranaportal.uol.com.br/agronegocio/agropecuaria-ficaestagnada-em-2018/. Acesso em: 18, abr. 2019.

PATTERSON, D.A.; HENNESSY, J.L. Organização e projeto de computadores: a interface hardware/software. 5a ed., São Paulo, SP.: Elsevier, 2017. 
PORTAL BRASILEIRO SOBRE IDENTIFICAÇÃO DIGITAL (CRYPTO ID). Releases. Disponível em: <https://cryptoid.com.br/mercado/gartner-anuncia-que-o-mercadomundial-de-software-de-gestao-de-relacionamento-de-clientes-cresceu-156-em-2018/>. Acesso em: 04 abr. 2020.

PORTAL DE TECNOLOGIA DA GLOBO.COM (TECHTUDO). Releases. Disponível em: $<$ https://www.techtudo.com.br/noticias/2018/01/relembre-nove-coisas-que-todo-mundofazia-na-epoca-da-internet-discada.ghtml/>. Acesso em: 28 mar. 2020.

PURI, V.; NAYYAR, A.; RAJA, L. Agriculture drones: A modern breakthrough in precision agriculture, Journal of Statistics and Management Systems, 20:4, 507-518, 2017, DOI: 10.1080/09720510.2017.1395171.

ROSA, M. V. de F. P. do C.; ARNOLDI, M. A. G. C. A entrevista na pesquisa qualitativa: mecanismo para validação dos resultados. Belo Horizonte: Autêntica, 2006.

SACHS, I. Rumo à "agricultura plurifuncional". Disponível em: < https://pagina22.com.br/2013/07/11/rumo-a-agricultura-plurifuncional/ > Acesso em: 15 julho. 2019.

SCHIMMELPFENNIG, D. Farm Profits and Adoption of Precision Agriculture, ERR-217, U.S. Department of Agriculture, Economic Research Service, October 2016.

SEBRAE. Datasebrae. Disponível em: <https://datasebrae.com.br/perfil-do-produtorrural/>. Acesso em: 06 nov. 2020.

SILVA, M.E.D.; ANDRADE, P.H. da S. Aplicação de ferramentas de gestão de custos na fazenda São Gonçalo, no município de Banabuiú - CE. Revista expressão católica. v.1 pág. 67-75, jul-dez, 2016.

SILVEIRA, A. C. M; SCHWARTZ, C. TIC e relações afetivo-produtivas na agricultura familiar: enfrentando o isolamento e a exclusão digital. In: CIRCUITO DE DEBATES ACADÊMICOS, v.1. 2011. Anais... [S.I.]: [s.n.], 2011. 
SIMIONI, F.J.; BINOTTO, E.; BATTISTON, J. Informação e gestão na agricultura familiar da região Oeste de Santa Catarina. Revista Brasileira de Gestão e Desenvolvimento Regional. Taubaté, São Paulo, v. 11, n. 3, p. 152-177, set-dez/2015.

TEIXEIRA, B.E. Utilização de veículo não tripulado de asa fixa no monitoramento e coleta de imagem de animais e ambientes em propriedades rurais. Dissertação de Mestrado. Programa de gestão e inovação na indústria animal - GIIA. Faculdade de zootecnia e engenharia de alimentos - FZEA. Universidade de São Paulo. Pirassununga, SP: 2016.

UNIVERSIDADE FEDERAL DE MINAS GERAIS (UFMG). História da internet Brasil. Disponível em:

http://homepages.dcc.ufmg.br/ mlbc/cursos/internet/historia/Brasil.html>. Acesso em: 18 mar. 2020.

VIEIRA, E.P.; CARNEIRO, T.D.; F.R. A relevância da informação contábil na gestão das empresas do agronegócio da região noroeste do Estado do Rio Grande do Sul. RAC Revista de Administração e Contabilidade - CNECEdigraf - Ano 14 - n. 27 - jan/jun. 2015 - p.35-70.

YIN, R.K. Estudo de caso: planejamento e métodos. $2^{\underline{a}}$ ed. Porto Alegre: Editora Bookman, 2001. 


\section{APÊNDICE 1 - QUESTIONÁRIO DA PESQUISA}

\section{TERMO DE CONSENTIMENTO LIVRE E ESCLARECIDO PARA PESQUISAS ONLINE}

Você está sendo convidado(a) como voluntário(a) a participar da pesquisa: "Estudo de cadeias do agronegócio: tendências e especificidades - Potencial de gestão de empreendimentos rurais vis-à-vis acesso à rede de computadores no Brasil: Uma proposta de ferramenta de gestão para controle e organização das informações financeiras" e que tem como objetivo contribuir para o aumento do conhecimento de segmentos específicos e ou tendências de mercado, não somente dentro de um contexto teórico e prático, mas visando entender a resultante entre atores ligados a esta cadeia, desde fornecedores de insumos, passando por produtores, beneficiadores, distribuidores e consumidores. Acreditamos que ela seja importante para: criar reflexão entre formas de gestão e presença de inovação com a resultante no desenvolvimento do agronegócio brasileiro e analisar boas práticas nesse setor com possibilidade de estudar relações entre os atores que compõem os diferentes cenários estudados.

Participação do estudo - Sua participação no referido estudo será de responder um questionário online através do sistema Google formulários, onde levará o tempo médio de 15 a 20 minutos, podendo ser respondido em qualquer local e dispositivo que tenha acesso a internet.

Riscos e Benefícios - Não há benefícios diretos ao participante da pesquisa. Alerta-se, também que é possível que aconteçam os seguintes desconfortos ou riscos: desconforto gerado pelo tempo utilizado para colaborar com a pesquisa e risco de vazamento de dados.

Sigilo e Privacidade - Sua privacidade será respeitada, ou seja, seu nome ou qualquer dado ou elemento que possa, de qualquer forma, Ihe identificar será mantido em sigilo. Os pesquisadores se responsabilizam pela guarda e confidencialidade dos dados, bem como a não exposição dos dados da pesquisa.

Autonomia - É assegurada a assistência durante toda a pesquisa, bem como garantido o livre acesso a todas as informações e esclarecimentos adicionais sobre o estudo e suas consequências, enfim, tudo que o participante queira saber antes, durante e depois de sua participação. Declaramos que é permitido se recusar a participar do estudo, ou retirar seu 
consentimento a qualquer momento, sem precisar justificar, e de, por desejar sair da pesquisa, não sofrerá qualquer prejuízo à assistência que tenha recebido.

Ressarcimento e Indenização - O pesquisador se responsabiliza por qualquer dano eventual decorrente da participação da pesquisa.

Contatos - Pesquisador Responsável: Celso da Costa Carrer

Telefone para contato: (19) 35654338

E-mail para contato: celsocarrer@usp.br

Comitê de Ética - O Comitê de Ética em Pesquisa em Seres Humanos (CEP) é composto por um grupo de pessoas que estão trabalhando para garantir seus direitos como participante sejam respeitados, sempre se pautando da Resolução 466/12 do CNS. Ele tem a obrigação de avaliar se a pesquisa foi planejada e se está sendo executada de forma ética. Caso você considere que a pesquisa não está sendo realizada da forma como você imaginou ou que está sendo prejudicado de alguma forma, você pode entrar em contato com o Comitê de Ética da FZEA/USP (cepfzea@usp.br) que está localizado na Av. Duque de Caxias Norte 225, Campus USP, Pirassununga-SP, cep 13635-900.

Declaração - Declara-se que todas as informações presentes neste Termo são de responsabilidade dos pesquisadores envolvidos e estes estarão à disposição para quaisquer dúvidas e/ou esclarecimentos de informações do projeto. Tendo os participantes sido esclarecidos quanto ao teor de todo o aqui mencionado e compreendido a natureza e o objetivo do já referido estudo, entende-se o seu livre consentimento em participar, estando totalmente ciente de que não há nenhum valor econômico, a receber ou pagar, por sua participação.

Uso de Imagem - Não haverá utilização de imagem, gravação ou áudio.

Este projeto de pesquisa foi aprovado pelo CEPH-FZEA em 11/09/2019 com No. De PARECER DE APROVAÇÃO: 90294318.2.0000.5422

Celso da Costa Carrer

Pesquisador Principal 
1) O empreendimento rural possui alguma linha de financiamento?

( ) sim - qual? ( ) não

2) Qual(is) o(s) ramo(s) de atividade(s), produto(s) ou serviço(s) comercializado(s) pelo empreendimento rural?

3) Qual(is) a(s) localidade(s) municipal(is) e estadual(is) da(s) propriedade(s)?

4) Você é proprietário, gestor ou arrendatário?

5) Como está estruturado a composição empresária da propriedade?

( ) familiar ( ) capitalista ( ) arrendamento ( ) outro - qual?

6) Quem faz a gestão da propriedade?

( ) arrendatário ( ) proprietário ( ) gestor profissional ( ) outro qual?

7) Qual a faixa etária de quem faz a gestão da propriedade?

( ) até 24 anos ( ) 25 a 34 anos ( ) 35 a 44 anos ( ) 45 a 54 anos ( ) 55 a 64 anos ( ) 65 a 74 anos ( ) 75 anos e mais

8) Qual o nível de escolaridade de quem faz a gestão da propriedade?

( ) nunca frequentou escola ( ) antigo primário (elementar) ( ) regular do ensino fundamental ou $1^{\circ}$ grau ( ) regular do ensino médio ou $2^{\circ}$ grau ( ) classe de alfabetização - CA ( ) superior graduação ( ) mestrado ou doutorado ( ) outro - qual?

9) Qual o tamanho da propriedade?

( ) até 5 hectares ( ) de 6 a 20 hectares ( ) de 21 a 50 hectares ( ) mais que 50 hectares

10) Quantos funcionários/membros familiares o empreendimento rural possui? 
( ) até 5 ( ) de 6 a 10 ( ) de 11 a 20 ( ) mais que 20 ( ) não se aplica

11) O empreendimento rural mantém algum tipo de controle de custos produtivos?

( ) $\operatorname{sim}-$ qual? ( ) não

12) O empreendimento rural possui algum tipo de controle financeiro?

( ) $\operatorname{sim}($ ) não.

13) Caso a resposta na questão anterior tenha sido "Sim", assinale o tipo de controle utiliza:

( ) caderno de anotações ou caderneta ( ) fichas eletrônicas ( ) planilhas de excel ( ) sistemas computacional ( ) outro - qual?

14) Como o empreendimento rural registra as movimentações financeiras?

( ) via contabilidade ( ) via livro caixa ( ) não registra as movimentações financeiras ( ) outro?

15) Caso registra as movimentações financeiras, a escrituração é feita:

( ) no próprio empreendimento rural ( ) em escritório externo de contabilidade ( ) não se aplica, pois não há registro das movimentações financeiras ( ) outro

16) Qual(is) o(s) regime(s) tributário(s) adotado(s) pelo empreendimento rural no momento?

( ) lucro real ( ) lucro presumido ( ) simples nacional ( ) imposto de renda da pessoa física ( ) outro - qual?

17) Quais as principais informações/índices levados em consideração para a sua tomada de decisão gerencial?

18) Na sua opinião, os resultados do empreendimento rural (lucro) estão melhorando ou piorando nos últimos 5 anos? Quais variáveis ou situações você acredita que estejam influenciando o seu negócio? Por favor, faça um breve relato. 
19) Você costuma acompanhar os preços e informações sobre o comportamento do mercado? Quais as fontes mais utilizadas? Você está satisfeito com a base de informações que recebe? Por favor, faça um breve relato.

20) Como você observa o mercado que está inserido para o futuro (visão de negócio)?

21) Que tipo de serviço na área de gestão você mais sente falta?

22) Você estaria disposto a conhecer melhor uma proposta de sistema de gestão que viesse a contribuir na sua tomada de decisão?

( ) Sim ( ) Não

23) Tem acesso à internet?

( ) sim, na propriedade ( ) sim, fora da propriedade ( ) não tenho e não pretendo ter ( ) não tenho mas pretendo ter

24) Caso a resposta anterior tenha sido sim, qual o tipo de conexão:

( ) via cabo de tv ou fibra ótica ( ) via linha telefônica (DSL) ( ) via rádio ( ) via satélite ( ) móvel - via modem ou chip 3G ou 4G ( ) não sei opinar

25) Caso a resposta 23 (acesso à internet) tenha sido sim, qual a velocidade download da conexão:

( ) abaixo de 1 Mbps ( ) 2Mbps ( ) de 3Mbps até 10Mbps ( ) acima de 10Mbps

26) Quais recursos tecnológicos (hardware) utiliza para acesso à internet:

( ) computador de mesa ( ) notebook ( ) tablet ( ) celular ( ) outro:

27) Você conhece o sistema Nav Agro Brasil?

( ) Sim ( ) Não

28) Gostaria de receber informações detalhadas sobre o sistema Nav Agro Brasil?

( ) Sim ( ) Não 


\section{APÊNDICE 2 - ESTRUTURA FUNCIONAL DO SOFTWARE NAV AGRO BRASIL}

A configuração geral de acesso ao sistema é realizada pelo administrador, que baseado na negociação comercial, configura o perfil do futuro usuário: versão "smart" (para usuário com baixo nível de escolaridade) e versão "plus" (usuário com médio ou alto nível de escolaridade). Esses dois produtos têm a mesma finalidade, contudo na versão "smart" o usuário tem ao seu dispor uma gama de cadastros pré-definidos, necessitando apenas a inserção poucas informações do dia a dia da propriedade. Ao contrário, na versão "plus", há possibilidade de parametrizar os cadastros de acordo com a necessidade da informação e do perfil do cliente. Essa configuração pode ser feita pelo próprio usuário ou com apoio do suporte técnico. Essas duas opções de perfis apresentados ("smart" ou "plus") decorrem da identificação na pesquisa onde uma parcela dos empreendimentos rurais é gerido por proprietários, arrendatários ou gestores com níveis básico ou fundamental de educação. Após realizado essa etapa, o usuário terá a seguinte visão geral de acesso ao sistema conforme (Figura 61).

Figura 62 - Visão geral do sistema Nav Agro Brasil

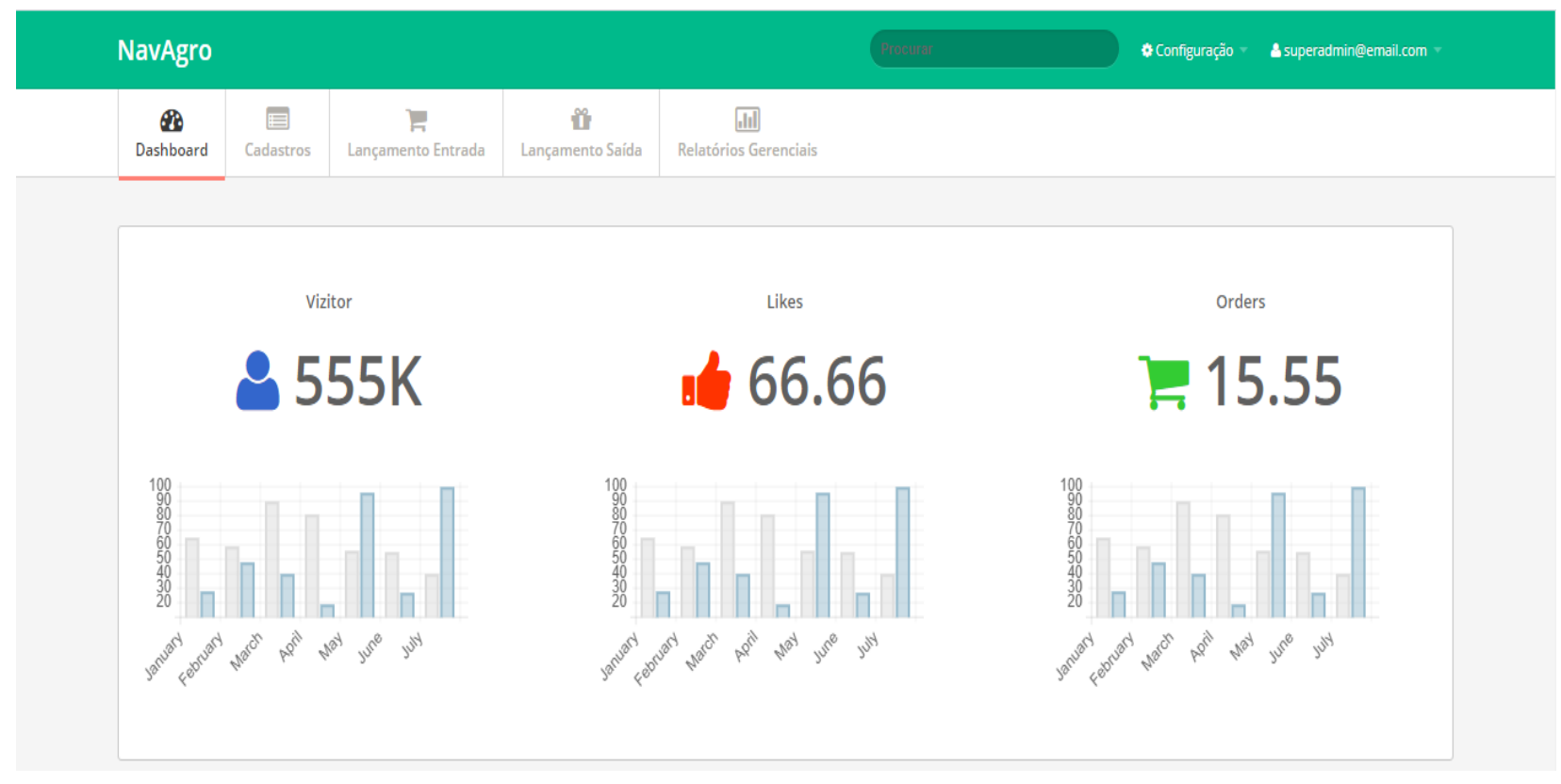

Fonte: Elaborado pelo autor. 


\section{ANEXO 1 - CERTIFICADO DE REGISTRO DO PROGRAMA DE COMPUTADOR}

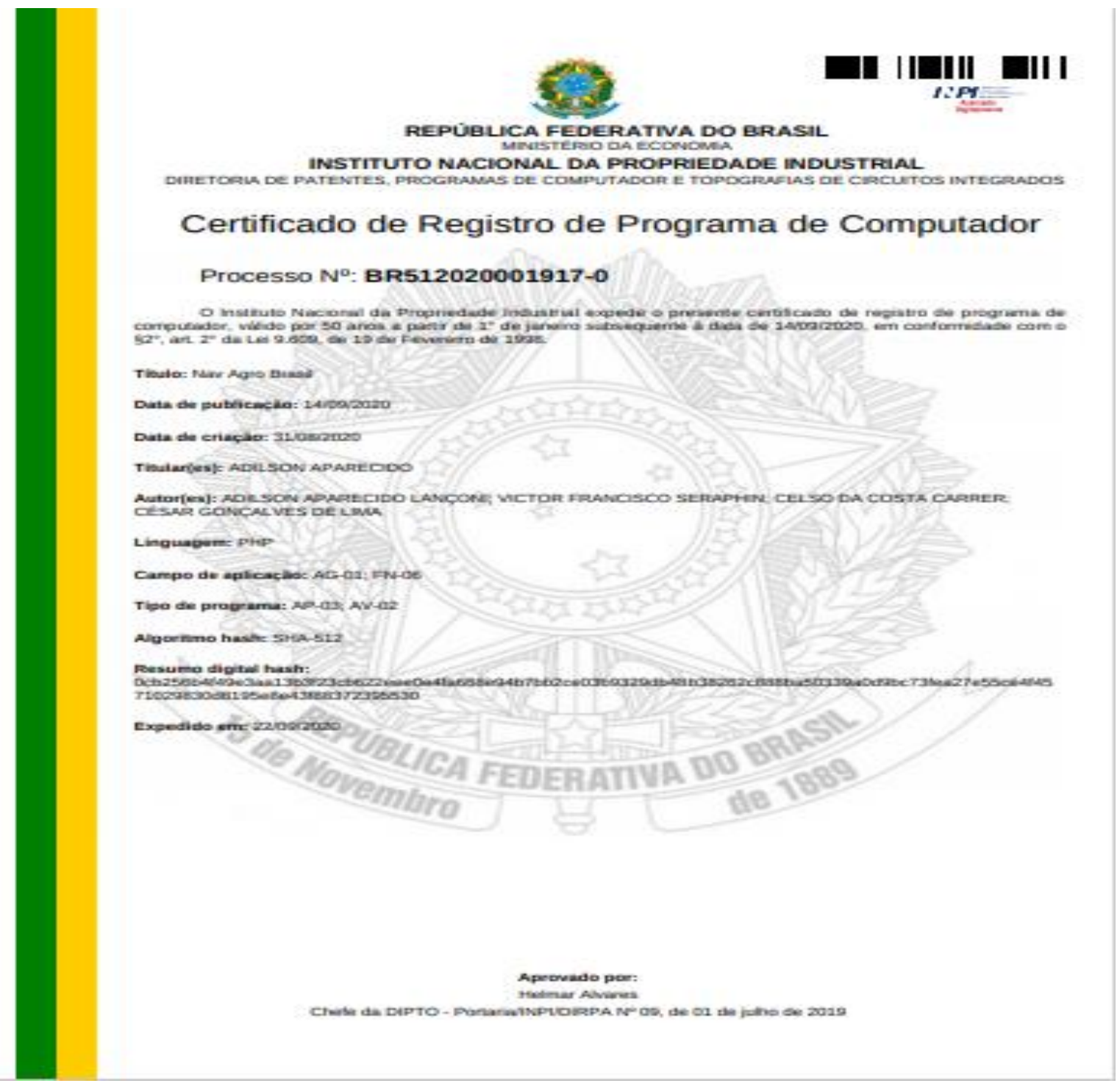

